Rodrigo Oliveira Salgado

\title{
Constituição e desenvolvimento: o mercado interno na Constituição de 1988
}

\author{
Dissertação de Mestrado apresentada ao \\ Departamento de Direito Econômico e \\ Financeiro, da Faculdade de Direito da \\ Universidade de São Paulo, sob a orientação do \\ Professor Titular Gilberto Bercovici.
}

São Paulo 


\section{RESUMO}

Esta dissertação procura analisar o artigo 219 da Constituição Brasileira sob a ótica das políticas econômicas do desenvolvimento. Em seu texto, o referido artigo garante como parte integrante do patrimônio nacional o mercado interno, prescrevendo seu incentivo a fim de proporcionar o desenvolvimento econômico, social e cultural, bem como a autonomia tecnológica e o bem-estar de toda a população. Partindo dos pressupostos teóricos da Constituição Federal de 1988 como sendo uma constituição dirigente, esta dissertação foca-se sobre o referido dispositivo encarando-o como artigo pertencente à chamada constituição econômica formal. Assim, esta pesquisa se propõe a estudar os três principais discursos nacionais sobre o desenvolvimento econômico, ao mesmo tempo em que busca na literatura econômico-constitucional as melhores análises sobre o referido artigo.

\section{PALAVRAS-CHAVE}

Constituição Econômica - Constituição Dirigente - Desenvolvimento Econômico Políticas de Desenvolvimento Econômico - Direito e Desenvolvimento - Mercado Interno - Patrimônio Nacional - Soberania 


\begin{abstract}
This study intends to analyze the article 219 of the Brazilian Constitution, under the view of the policies for economic development. In its text, the referred article grants the Brazilian internal market as part of the national patrimony. Further, the article prescribes its economic stimulus, intending to provide cultural, social and economic development, as well as social welfare and technological independence. Assuming that the Brazilian Constitution is a typical José Canotilho's directive constitution model, this study focuses on the referred article, facing it as a part of the Brazilian economic constitution. Thereby, proposes to study the three main national thesis about economic development, as the same time as it searches on the Brazilian constitutional and economic literature the best analysis on the cited article.
\end{abstract}

\title{
KEYWORDS
}

Economic constitution - Directive Constitution - Economic Development - Economic Development Policies - Law and Development - Domestic Market - National Patrimony Sovereignty 


\section{AGRADECIMENTOS}

Listar todas as pessoas responsáveis por me auxiliar nesta jornada é tarefa impossível. Entretanto, mais impossível seria a finalização desta dissertação sem a menção de pelo menos alguns nomes.

O interesse pelo conhecimento como modificador da sociedade possivelmente veio de meu pai, de quem herdei a predileção pela docência e a pesquisa científica. De outro lado, herdei de minha mãe a perene indignação com o mundo que me cerca. Estas duas características me são fundamentais, pois hoje o horizonte que se afigura parece ser mesmo a utilização da ciência como forma de catalisar minha indignação contra o injusto do mundo.

Mas meus aprendizados familiares não se encerram com meus pais. De meu irmão, aprendi que qualquer desafio que a vida possa impor não pode ser suficiente para a desistência de um projeto. Superar as adversidades é uma constante em sua vida, que desde cedo aprendi a valorizar.

Por isso, meus primeiros agradecimentos não poderiam ser para outros que não eles. Agradeço à minha família por todo o incondicional apoio.

Em outra ponta aparecem meus amigos que, por sorte, não são poucos. Por essas generosidades da vida, tenho por hábito assimilar as amizades de meus amigos. Desta forma, posso dizer que se fosse agradecer a todos, esta dissertação se transformaria em um interminável índice onomástico. Entretanto, isto não impede de que os cite por suas origens: os da minha infância em São José dos Campos, com quem tenho o privilégio do convívio quase diário até hoje; do colégio; da banda; da faculdade de Direito do Mackenzie; do movimento estudantil; da política; das administrações pelas quais passei; os colegas de trabalho que se tornaram amigos; e os "assimilados", principalmente os jornalistas.

Registro aqui, apenas para não configurar a vagueza dos títulos sem nome, meus amigos com quem convivo diariamente: Ivandick dos Santos, Fernando Neisser, Fernando Yokota, 
Nucélio Lemos, Luís Brasilino e o distante, mas não menos amigo, Mateus Alves. A todos, obrigado por tudo.

Não poderia deixar de agradecer a um amigo em especial, com o qual tenho tido o privilégio constante de conviver e aprender. Gilberto Bercovici, obrigado por tudo e, principalmente, por acreditar em mim. Poucas pessoas na academia terão o privilégio que eu tive, de ter um orientador tão acessível e sincero, sem perder nunca a seriedade da pesquisa. Meus sinceros votos de agradecimento pela impecável orientação.

Por fim, e mais importante, devo registrar aqui a pessoa que é sem dúvida a maior responsável pelo fim de mais esta etapa. Ana, meu amor, esta dissertação é para você. Você é a razão de tudo isso. Esteve presente em todos os momentos, especialmente nos mais difíceis. Mesmo com todas as vicissitudes que a vida te trouxe, nunca saiu do meu lado. Obrigado por tudo. Agradeço seu amor, seu apoio, sua pertinência intelectual, sua paciência, sua generosidade e bondade. Agradeço o seu carinho e sua incansável mania de ter fé na vida. Te amo. 


\section{SUMÁRIO}

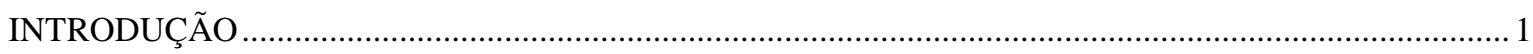

CAPÍTULO 1. PARADIGMAS TEÓRICO-CONSTITUCIONAIS: A CONSTITUIÇÃO ECONÔMICA E O

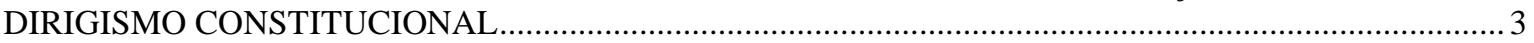

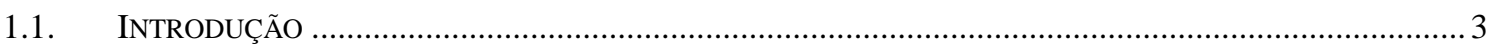

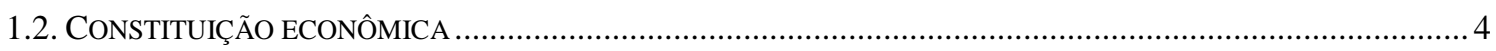

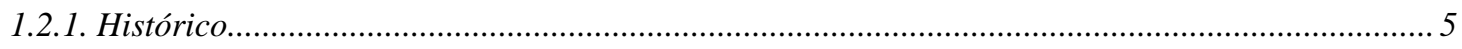

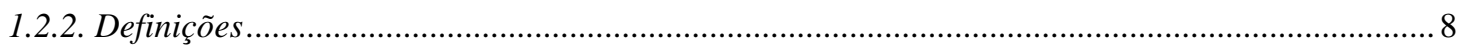

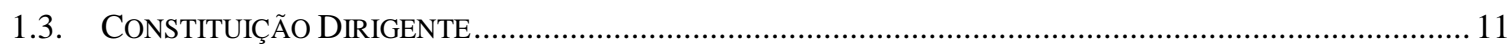

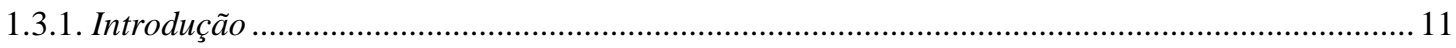

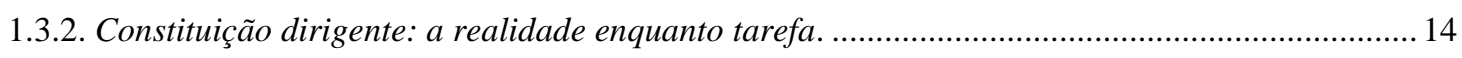

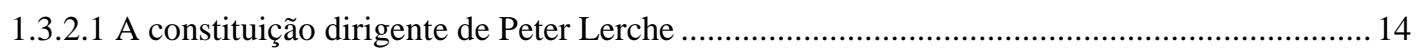

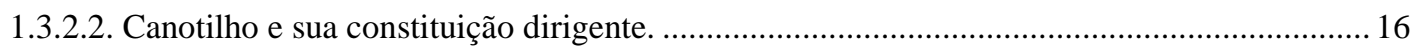

1.3.2.2.1. O CONCEITO DE NORMAS PROGRAMÁTICAS. ................................................. 20

1.3.2.3. O problema da legitimação-legitimidade na constituição dirigente. .................................... 24

1.3.2.3.1. Implicações do debate sobre legitimidade e legitimação nesta dissertação................. 25

1.3.2.3.2. legitimação-legitimidade da constituição dirigente e uma teoria da constituição

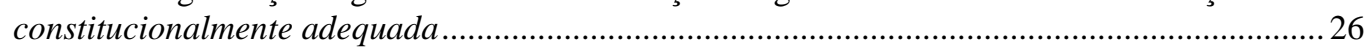

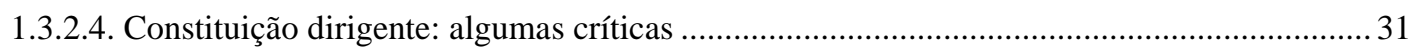

1.3.2.4.1. Críticas quanto à liberdade, conformação do legislador e discricionariedade.............. 33

1.3.2.4.2. críticas quanto às imposições constitucionais sobre as tarefas e fins do estado previstos

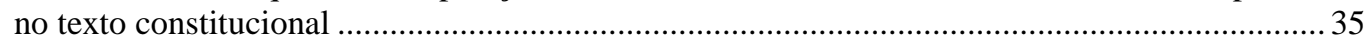

1.3.2.5. a constituição dirigente morreu. viva a constituição dirigente!.......................................... 36

1.3.3. A Constituição Federal de 1988 enquanto uma constituição dirigente ........................................ 40

CAPÍTULO 2. DESENVOLVIMENTO ECONÔMICO: A DISPUTA DE UM PROJETO

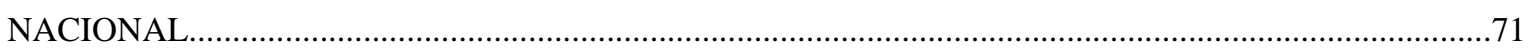

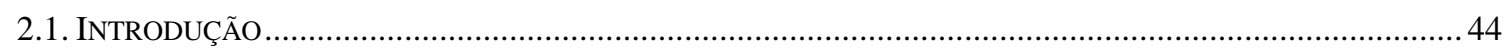

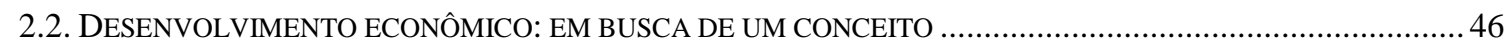

2.2.1. Desenvolvimento econômico e crescimento: variações de um mesmo sentido ............................ 47

2.2.2. Desenvolvimento enquanto processo histórico. ...................................................................... 49

2.2.3. Desenvolvimento econômico e inovação............................................................................... 51

2.3. ALGUNS CONCEITOS CLÁSSICOS DE DESENVOLVIMENTO ECONÔMICO ...............................................56

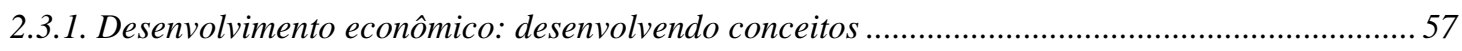

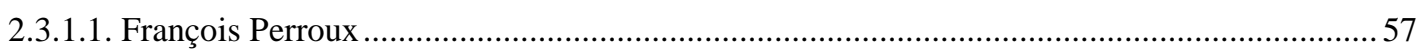

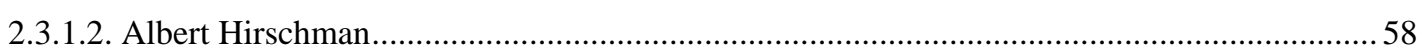




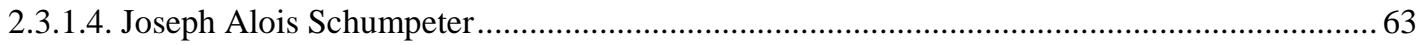

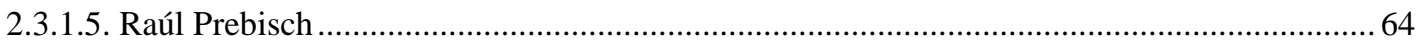

2.4.TRANSPOSIÇÃO DO CONCEITO DE DESENVOLVIMENTO ECONÔMICO À REALIDADE BRASILEIRA: A

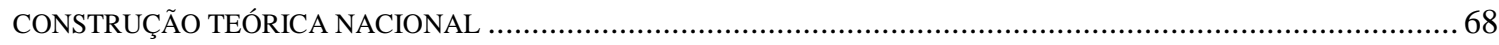

2.4.1. Projetos para o desenvolvimento econômico nacional ............................................................. 71

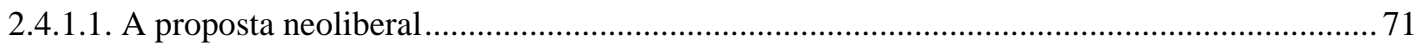

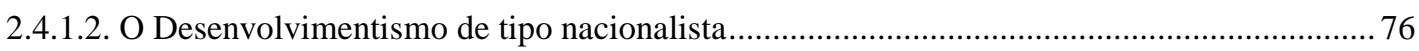

2.4.1.3. O Desenvolvimentismo de tipo "não nacionalista" ...........................................................8 87

CAPÍTULO 3. DISCURSOS SOBRE O MERCADO INTERNO E O PATRIMÔNIO NACIONAL: ALGUMAS ANÁLISES DO ARTIGO 219 DA CONSTITUIÇÃO FEDERAL.........................................98

3.1. ViSÕES DE UMA ECONOMIA LIBERAL: TERCIO SAMPAIO FERRAZ E JoSÉ AFONSO DA SilvA .................94

3.1.1. O Estado como regulador econômico: Tercio Sampaio Ferraz Jr. ............................................. 95

3.1.2. O mercado enquanto espaço social: a posição de José Afonso da Silva ....................................... 99

3.2. DefeSA do CAPITAL NACIONAL: A POSIÇÃo DE MANOEL GONÇALVES FERREIRA FILHO ..................... 104

3.3. A SUPERAÇÃO DO SUBDESENVOLVIMENTO PELA REAFIRMAÇÃO DA SOBERANIA NACIONAL: O MERCADO INTERNO COMO MOTOR DO DESENVOLVIMENTO ECONÔMICO............................................................. 108

CAPÍTULO 4. ESTUDO DO ARTIGO 219 DA CONSTITUIÇÃO FEDERAL DE 1988.........................118

4.1. INTRODUÇÃ

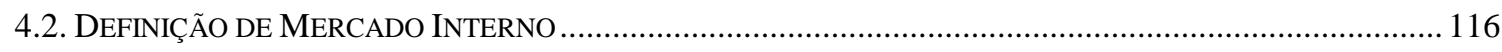

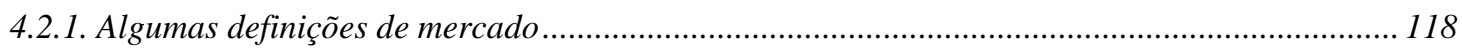

4.2.2. Definição geográfica e histórico-econômica do mercado interno ............................................. 122

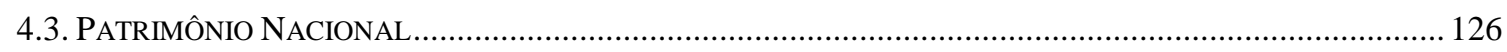

4.3.1. Conceito de patrimônio e de patrimônio privado ......................................................................... 122

4.3.1.1. Patrimônio público..................................................................................................... 130

4.3.1.3. Patrimônio nacional .................................................................................................. 141

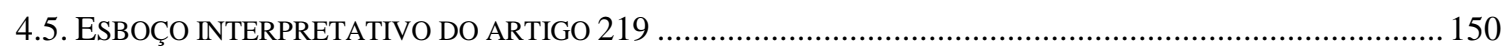

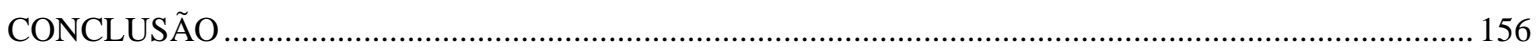




\section{INTRODUÇÃO}

A discussão sobre o desenvolvimento nacional não é nova. Presente há quase cem anos no ideário intelectual brasileiro, a superação do quadro endêmico de subdesenvolvimento do país permeou todo o espectro político brasileiro. Entre os mais radicais da esquerda revolucionária aos ultra-liberais, pulularam as teses sobre as formas de tornar o Brasil um país digno não para poucos, mas para todos.

Muitas teses, muitas discordâncias. Mesmo a mais apressada das leituras sobre o tema conclui que, apesar das limitações históricas do país em formar um corpo de intelectuais que pensem a existência da nação, não faltam teses sobre o tema. Como dito, até quem normalmente descarta a organização da sociedade em prol da superação do subdesenvolvimento se envolveu com o tema. Dentre as inúmeras diferenças, parece mesmo que a única concordância seja com o fato de que o Brasil era - e é - uma nação subdesenvolvida.

Partindo desta consideração, esta pesquisa se pretende uma gota ao oceano de ideias sobre os instrumentos à disposição do país para a superação do subdesenvolvimento. Imbuída de uma espécie de função social da pesquisa, esta dissertação levanta, dentro das ciências jurídicas, elementos que possam contribuir para a consecução de políticas que visem à superação das imensas disparidades sociais que teimam em persistir, mesmo após cem anos de discussão sobre o tema e ao menos uma década de intensos programas de redistribuição de renda que, embora paliativos, amenizaram o estágio catastrófico de desigualdade que o Brasil ostenta.

À primeira vista, a ferramenta aqui utilizada é o Direito econômico. O ramo da ciência jurídica classificada pelo professor Fabio Konder Comparato como pertencente aodireito aplicado em seu seminal $O$ Indispensável Direito Econômico, tem sua finalidade garantida no ato de "traduzir normativamente os instrumentos de política econômica do Estado." 1

\footnotetext{
${ }^{1}$ COMPARATO, Fabio Konder. O indispensável direito econômico in. Revista dos Tribunais, São Paulo, vol. 353, 1955, p. 26.
} 
Desta forma, se o ferramental pertence ao Direito econômico, a ferramenta aqui discutida é, sem dúvida, o Estado.

A questão é que dentro das ciências jurídicas, a norma que reflete a organização de um Estado é a Constituição.

Por isso, a dissertação aqui iniciada procurará investigar um artigo específico do texto constitucional brasileiro, o artigo 219. Seu conteúdo, como se verá ao longo da pesquisa, trata de inserir o mercado interno do país dentro do patrimônio nacional, prescrevendo que ele - o mercado interno - deve ser incentivado a fim de proporcionar o desenvolvimento econômico, social e cultural, bem como o bem-estar de seu povo e a autonomia tecnológica.

No mais, a hipótese da dissertação que aqui se inicia é que o referido artigo traduz, juntamente com os artigos $3^{\circ}$, II e 170, I, não apenas o desenvolvimento nacional como objetivo da República. Mais do que isso, o artigo 219 da Constituição reflete um modelo específico de desenvolvimento, aqui chamado de desenvolvimentismo "nacionalista" ou nacional-desenvolvimentismo.

Partindo do estudo da Constituição como texto dirigente e focando no estudo das normas da chamada constituição econômica formal, esta pesquisa estudará as principais correntes que debateram o desenvolvimento no país, por meio de seus ícones mais importantes. Em seguida, faremos uma revisão bibliográfica acerca do que já foi escrito sobre o artigo 219 da Constituição e, por fim, encerraremos com a análise pormenorizada do dispositivo, traçando um esboço interpretativo do mesmo.

No mais, espera-se que de alguma forma esta pesquisa possa servir para auxiliar, ainda que indiretamente, a superação do persistente quadro de subdesenvolvimento que o Brasil parece se esforçar em manter. 


\title{
CAPÍtUlo 1. PARADIGMAS TEÓRICO-CONSTITUCIONAIS: A CONSTITUIÇÃO ECONÔMICA $\mathrm{E} \quad \mathrm{O}$ DIRIGISMO CONSTITUCIONAL
}

\author{
1.1. Introdução
}

Inserir o mercado interno como parte integrante do patrimônio nacional não é simples ato retórico. Caso queira-se levar a cabo o cumprimento por completo da Constituição Federal de 1988, deve-se ter em conta que a proposição prevista no artigo 219 deve gerar sérias consequências na gestão do Estado, tanto em termos econômicos, quanto políticos e sociais.

A observância do referido artigo será feita em momento oportuno nesta dissertação. Entretanto, ao tratar do assunto, lembramos que antes de ser um comando políticoeconômico ao Estado, o dispositivo em questão faz parte de uma constituição. Especificamente, trata-se da Constituição da República Federativa do Brasil, atualmente em vigor.

Se o objetivo do presente trabalho é, ao analisar o referido dispositivo, engendrar qual foi o sentido político-econômico em que a proteção ao mercado interno foi instituída, cabe, antes de qualquer coisa, proceder dois levantamentos que são pressupostos da presente pesquisa.

O primeiro levantamento dogmático-constitucional trata de onde o referido artigo estaria inserido dentro da Constituição de 1988. Nesta parte não procederemos um levantamento necessariamente topográfico da localização do artigo 219. Ainda que a reflexão sobre o capítulo em que o dispositivo está inserido seja necessária, o foco é conceituar onde especificamente o dispositivo se compõe com outros. Trata-se, na verdade, de pontuar a chamada constituição econômica, no qual o artigo está inserido.

Desta forma, buscam-se arrolar quais são os artigos que tratam do mesmo tema que aquele que será analisado posteriormente. Porém, para inseri-lo neste conjunto de normas constitucionais, será necessário primeiramente conceituar o que seria a chamada 
constituição econômica, dentro do contexto da Constituição Brasileira de 1988. A compreensão deste termo é condição para que se proceda a análise pormenorizada da inserção da defesa do mercado interno dentro da constituição brasileira.

Em um segundo momento, esta dissertação abordará outro conceito referente à dogmática constitucional: a Constituição dirigente, de José Joaquim Gomes Canotilho.

Apreender este conceito é fundamental para que se entenda que não só a defesa do mercado interno compõe um conjunto de regras da organização econômica do Estado brasileiro como também é um dispositivo incluído e imbuído de um programa específico para o Estado. Entender a Constituição Brasileira sendo um texto dirigente significa imputar ao texto estudado mais do que uma mera descrição de tarefa isolada dada ao Estado nacional pelo legislador constituinte. É, na verdade, compreender que o dispositivo se insere em uma série de normas programáticas que em conjunto indicam um comando específico à gestão da coisa pública no Brasil.

É por isso que para esta tarefa será necessário buscar o auxílio da tese sobre o dirigismo constitucional. Será com este suporte teórico que a junção dos fatores políticos e históricos que conformaram a construção da atual Carta Constitucional brasileira que o estudo proposto transcenderá o plano político-histórico para o campo dogmático-constitucional.

\subsection{Constituição econômica}

O surgimento do conceito da constituição econômica está bastante atrelado a um momento histórico específico da Europa. Em que pese a ideia de constituição econômica poder ser aplicada à praticamente todos os textos constitucionais modernos, seu conceito nasce na Europa pós Primeira Guerra Mundial. O fenômeno constitucional-econômico tem seu berço na constituição mexicana de 1917. Entretanto, será a partir da Alemanha de Weimar que será amplamente difundido.

O recorte histórico oferecido pressupõe mais do que situar o referido termo no tempo. Entender o que significa a premissa da constituição econômica é peça fundamental não apenas a esta dissertação, mas também à própria essência do Direito Econômico. É pela 
captura do conceito de constituição econômica em sentido formal, que se torna possível delimitar qual política econômica que determinado texto constitucional abarca.

Entender o conceito citado é requisito para que se conceda o arcabouço teoréticoconstitucional à análise do artigo 219 como sendo parte integrante de um determinado programa. Em outros termos, para que seja possível vislumbrar qual é o sentido políticoeconômico em que a defesa do mercado interno está inserida na Carta Constitucional de 1988, faz-se necessário que se clarifiquem quais são os dispositivos constitucionais que compõem a chamada constituição econômica em sentido formal. É pela compreensão teórica sobre o conjunto de dispositivos constitucionais que engendram um modelo de política econômica que será possível garantir o substrato teórico-constitucional à hipótese apresentada aqui.

Desta forma, antes que se inicie de fato a análise estrita do dispositivo supracitado, discorreremos algumas linhas sobre o tema.

\subsubsection{Histórico}

Como citado anteriormente, parece não haver muitas dúvidas sobre o nascimento do conceito de constituição econômica.

O conceito de constituição econômica nasce juntamente com as mudanças nas próprias constituições. Isto não significa que não existam teorias que apontem que as constituições econômicas existem muito antes deste período. Apesar de esta questão ser abordada no próximo item deste capítulo, vale a observação que a análise de uma constituição econômica está ligada ao estudo dos dispositivos reguladores da atividade econômica de determinado Estado, independentemente da época em que o texto foi escrito ${ }^{2}$.

As profundas mudanças que o fim da Grande Guerra ensejará aos Estados Nacionais repercutirão não apenas no que tange seus textos constitucionais. As indeléveis alterações no próprio conceito de Estado-nação modificarão também a concepção de participação do

\footnotetext{
${ }^{2}$ Por óbvio, as leis consideradas enquanto "constituições" da antiguidade ou mesmo Idade Média, têm esta metodologia de análise de seu texto comprometida, dado que as formações econômicas daqueles períodos guardam pouquíssima similaridade com os modelos pós-iluministas.
} 
Estado na vida econômica de suas nações. Além de progressivamente incutir às novas constituições que nasciam no pós-guerra uma série de garantias aos trabalhadores e alargar os direitos civis, as leis fundamentais em questão começam a tratar de uma progressiva escalada na intervenção do Estado nos processos econômicos nacionais.

Dentre as possíveis causas desta sensível alteração nos paradigmas comportamentais dos Estados está possivelmente a escalada das mobilizações sociais por todo o ocidente. Aliás, conforme aponta Vital Moreira, a primeira geração de textos constitucionais que pretenderam incursões dentro da regulação econômica das nações está intimamente atrelada a processos revolucionários, bem sucedidos ou não ${ }^{3}$. É o caso das Constituições do México de 1917, de Weimar em 1919, da Espanha de 1931 e da União Soviética de 1918. O jurista português lembra ainda que não apenas as constituições oriundas de tais conjunturas trataram inicialmente do tema, mas também as constituições resultantes de processos contra-revolucionários preventivos ${ }^{4}$.

O ponto de união entre estas duas situações está menos na linha ideológica que pautou tais processos e mais nos resultados que eram esperados dos novos governos que se instituíam. Em todos os cenários, o que os textos constitucionais visam era, antes de qualquer coisa, "estabelecer uma nova ordem econômica, destinada a alterar a estrutura econômica existente",5.

Esta talvez seja a principal explicação da localização histórica do conceito de constituição econômica. Os últimos anos do século XIX e as primeiras décadas do século seguinte foram períodos de intensa reestruturação não apenas geopolítica dos países ocidentais como também do próprio conceito e fins do Estado.

É, portanto, no cenário de reestruturação do conceito de Estado que nascem as premissas objetivas para que mais tarde a ciência jurídica se debruce sobre o fenômeno da constituição econômica ${ }^{6}$.

\footnotetext{
${ }^{3}$ MOREIRA, Vital. Economia e Constituição. 2a Edição, Coimbra: Coimbra Editora, 1979, p. 91.

${ }^{4}$ Aponta Vital Moreira a utilização da expressão sob referência de Herbert Marcuse, que se valeu do termo para descrever os processos "revolucionários" fascista e nacional-socialista. In MOREIRA, Vital, cit., p. 91. ${ }^{5}$ MOREIRA, Vital. Op. cit., p. 91.

${ }^{6}$ É preciso apontar que antes de um conceito, a constituição econômica pode ser analisada enquanto fenômeno. Como visto, os dispositivos constitucionais que irão conformar o conceito surgem nas novas
} 
Visto o momento histórico do surgimento das constituições econômicas, resta assinalar quando o conceito foi efetivamente desenvolvido.

Como dito anteriormente, é a constituição mexicana de 1917 que primeiramente traz em seu corpo dispositivos que visam dar guarida à atividade econômica. ${ }^{7}$ Entretanto, será a constituição da República de Weimar, de 1919, que trará um capítulo específico sobre a ordem econômica do país. Por este motivo, não só a constituição alemã do primeiro pósguerra será considerada como o primeiro texto constitucional a possuir uma "constituição econômica”, como também será a academia teutônica que mais proficuamente tratará do tema. É o que aponta Simões Patrício, “foi também na doutrina germânica e a seguir à Primeira Grande Guerra que apareceu esse conceito, de um modo tão inovador quanto havia revestido, no século anterior, a elaboração da constituição política"8

Como descreve Vital Moreira, o surgimento do conceito de constituição econômica está intimamente ligado ao que se convencionou chamar de "cidadania econômica".

Kurt Ballerstedt se vale do termo cidadania econômica em um sentindo estritamente político, chegando a afirmar que haveria uma "conexão ideal entre socialismo e a constituição econômica". Conforme aduz Moreira,

“[A] representação de que a 'democracia política', com o seu parlamento, os seus partidos, o seu sufrágio universal, os seus direitos fundamentais, não passa de ilusão quando as condições econômicas impedem o 'cidadão' de efetivamente fazer uso dos seus direitos, motiva a ideia de transformá-lo também em 'cidadão econômico'. Assim como a revolução liberal tinha criado a cidadania política, era necessário agora atribuir a todos a cidadania econômica." 9

constituições na medida em que novas concepções políticas das funções do Estado são absorvidas pelas referidas cartas constitucionais. Assim, o conceito de constituição econômica é fruto do fenômeno político que inseriu em tais constituições os artigos que conformação a chamada constituição econômica em sentido formal.

${ }^{7}$ Os 27 e 123 da Constituição do México de 1917 tratavam, em suas versões originais, respectivamente, sobre a propriedade das terras e águas, subsolo e a devida desapropriação do território mexicano, e; sobre o trabalho e previdência social. Para mais informações, vide: ROUAIX, Ing. Pastor. Genesis de los artículos 27 y 123 de la constitución política de 1917. Puebla: Gobierno del Estado de Puebla, 1945, p. 199 a 242.

${ }^{8}$ PATRÍCIO, J. Simões. Curso de Direito Econômico. 2a Edição, Lisboa: Associação Acadêmica da Faculdade de Direito de Lisboa, 1981, p. 150.

${ }^{9}$ MOREIRA, Vital. Economia e Constituição. Op. cit., pp. 20 e 21. 
Ao longo da primeira metade do século XX, não foram poucos os teóricos alemães que se preocuparam em tratar do tema da constituição econômica. Autores como Hans Karl Nipperdey, Kurt Ballerstedt, Peter Badura e Ernst Benda são alguns dos principais professores alemães que ao seu tempo, se preocuparam em definir o que seria a constituição econômica. Se a ideia da constituição econômica fora colocada como problema jurídico após a Primeira Guerra Mundial, muito do que fora discutido tanto pelos juristas alemães como europeus como um todo foi publicado ao final dos anos de 1950. No caso português, as investigações de Vital Moreira, por exemplo, datam do início da década de 1970.

As razões para isso têm importante conteúdo geopolítico. Após a Primeira Grande Guerra, foi a Alemanha o país que mais radicalmente mudou, tanto em sua estrutura burocrática quanto política. A maior prova disso talvez seja a Constituição de 1919, que inseriu inúmeros direitos sociais e econômicos aos cidadãos alemães. A Carta de Weimaré, até hoje, o maior marco dentro do constitucionalismo econômico.

Uma vez situada as origens do conceito de constituição econômica, passamos agora a buscar entender efetivamente seu significado.

\subsubsection{Definições}

Ao longo da história, foram várias as definições conferidas ao termo "constituição econômica".

Conforme aduz Simões Patrício, apesar da academia italiana travar debates sobre a noção de constituição econômica, é na Alemanha que a ideia ganhará seus primeiros contornos teóricos. Com a Carta de Weimar, de 1919, surgem conceitos de constituição econômica (Wirtschaftsverfassung). Tais conceitos iriam desde os que

"reportariam à relação Estado-empresa privada (direitos fundamentais compreendidos na liberdade contratual e econômica e definição do poder público), até aos que a tomam como escolha política referida a um compromisso entre liberdade e vinculação econômica" ${ }^{\text {"10 }}$.

\footnotetext{
${ }^{10}$ PATRÍCIO, J. Simões. Op. cit., p. 152.
} 
Vimos que o processo de desenvolvimento teórico iniciado após a Primeira Guerra Mundial continuaria a dar frutos por todo o século XX. Tanto no entre guerras, quanto após a Segunda Guerra Mundial, foram vários os autores que se debruçaram sobre a questão da Constituição Econômica.

Dada esta pequena amostra, inferimos que o termo constituição econômica não é apenas polissêmico como também comporta em si mais de uma abordagem. Como lembra Cabral de Moncada, "[O] conceito de CE (constituição econômica) não é unitário. Na verdade, o objeto das normas que integram a CE não é sempre o mesmo" ${ }^{11}$. O professor português se vale do exemplo para diferenciar as constituições econômicas programáticas das constituições econômicas estatutárias.

Antes de aprofundar o debate sobre as diversas decorrências do conceito de constituição econômica, convém apontar o que seria efetivamente o termo. Para isso, usaremos a definição de Vital Moreira, referência em todas as obras brasileiras e portuguesas sobre o tema.

Conforme o insigne jurista português, "[A] constituição econômica é, pois, o conjunto de preceitos e
instituições jurídicas que, garantindo os elementos definidores de um
determinado sistema econômico, instituem uma determinada forma de
organização e funcionamento da economia e constituem, por isso mesmo,
uma determinada ordem econômica; ou, de outro modo aquelas normas
ou instituições jurídicas que, dentro de um determinado sistema e forma
econômicos, que garantem e (ou) instauram, realizam uma determinada
econômica concreta" 12 O que é possível inicialmente observar é o fato do conceito elencado não instituir a constituição econômica como uma mera descrição dos dispositivos presentes na constituição de determinado país. Isto ocorre porque ao tempo da construção desta definição a doutrina, por divergências internas, precedeu algumas decorrências da ideia de constituição econômica.

Ao determinar o conceito de constituição econômica enquanto sendo o "conjunto de preceitos e instituições jurídicas”, Vital Moreira assume que todos os dispositivos

\footnotetext{
${ }^{11}$ MONCADA. Luis S. Cabral de. Direito Econômico. 5a edição, Coimbra: Coimbra Editora, 2007, p. 127

12 MOREIRA, Vital. Economia e Constituição, Op. cit., p.41.
} 
constitucionais e toda a legislação e regulamentação infraconstitucional que trata sobre o tema está considerada como sendo a constituição econômica. Tal conceito, conforme aponta Antônio Luciano Sousa Franco, constitui a chamada constituição econômica material, que seria "o núcleo essencial de normas jurídicas que regem o sistema e os princípios básicos das instituições econômicas, quer constem quer não do texto constitucional" $" 13$.

Em outro sentido está o conceito de constituição econômica formal. Já citada anteriormente, tal constituição econômica seria o texto constitucional econômico em sentido estrito, ou seja, aquela que "insira decisões fundamentais que se reflitam no domínio da ordem econômica"14.

Esta diferenciação é importante não apenas para a dissertação, mas também para o próprio Direito Econômico. Tão importante quanto demonstrar que há um conjunto de dispositivos - esparsos ou não - em uma determinada constituição que trata da vida econômica de certa nação é apontar que o conjunto de regramentos constitucionais ou infra-constitucionais também compõem objeto de estudo do Direito Econômico.

Dada a natureza desta pesquisa, o principal conceito a ser apreendido é o de constituição econômica em sentido formal. Mais do que isso, é importante salientar aqui que os dispositivos que conformam a $\mathrm{CE}$ formal não necessariamente devem tratar da regulação econômica em sentido amplo, como por exemplo, as competências do Banco Central ou as limitações da atividade empresária para a manutenção de um capitalismo concorrencial. Dispositivos como a garantia do direito à propriedade privada ou outros direitos individuais com caráter econômico, também deverão compor a constituição econômica formal. É por esta razão que se garante a este conceito a ideia de que não há necessária limitação em termos de topografia constitucional.

Outra diferenciação importante proposta, entre outros, por Luis Cabral de Moncada é a caracterização entre as constituições econômicas programáticas e as constituições econômicas estatutárias.

\footnotetext{
${ }^{13}$ FRANCO, Antonio Luciano Sousa. Noções de Direito da economia, vol. I. Lisboa: Associação Acadêmica da Faculdade de Direito de Lisboa, 1982-1983, p. 93.

${ }^{14}$ MOREIRA, Vital.Op. cit., p. 113.
} 
Como aponta o autor, as constituições econômicas estatutárias "encerram o conjunto das normas que visam reagir sobre a ordem econômica de modo a provocar aí certos efeitos, modificando-a e alterando-a em certo sentido preestabelecido"15. Ou seja, as constituições econômicas estatutárias seriam aquelas que têm muito mais características reguladoras, que visam colocar parâmetros à atividade econômica.

Em outro sentido se encontram as constituições econômicas programáticas. Moncada as define enquanto aquelas que "visam estabelecer uma determinada ordem econômica alterando do mesmo passo a estrutura econômica existente, através da ação política dos órgãos do Estado",16

A captura desta diferença é fundamental para a presente dissertação. Conforme poderá ser percebido ao longo desta pesquisa, as teses sobre o dirigismo constitucional, somadas à noção de uma constituição econômica programática formam o sustentáculo para a conformação de que a defesa do mercado interno pela União é parte integrante de um projeto econômico-constitucional específico, cunhado a partir de 1988.

\subsection{Constituição Dirigente}

\subsubsection{Introdução}

O debate acerca de nossa Constituição Federal ser ou não dirigente não é novo em nosso país. Desde a criação do texto constitucional em 1988, há um número considerável de constitucionalistas brasileiros que apontam nossa Carta Constitucional como sendo, nos moldes apontados por José Joaquim Gomes Canotilho, uma constituição dirigente.

Não obstante, também é farta a discussão sobre a validade das premissas da constituição dirigente. Revisitada pelo próprio formulador, a tese de que força diretiva desta espécie

\footnotetext{
${ }^{15}$ MONCADA. Luis S. Cabral de. Direito econômico. Op. Cit., p. 127.

${ }^{16}$ Idem ibidem, p. 127.
} 
constitucional seria calcada em um projeto transformador foi questionada por Canotilho, que reviu algumas vezes suas posições ${ }^{17}$ ou mesmo aprofundou-as.

Como se verá a seguir, mesmo sob críticas ${ }^{18}$, é grande o número de autores que preserva a ideia de que nosso texto constitucional é um texto dirigente. Dentre os inúmeros fatores que serão analisados à frente, talvez o principal indício de que o Brasil esteja de fato sob a égide de uma Constituição dirigente seja a lógica intrínseca de um texto que "define, por meio das chamadas normas constitucionais programáticas, fins e programas de ação futura no sentido de melhoria das condições sociais e econômicas da população." 19

Porém, antes de definir efetivamente o que é um texto constitucional - aos moldes de Canotilho - dirigente, busca-se entender a necessidade de colocação deste conceito no presente trabalho.

Assim, a questão que transparece aqui é demonstrar qual seria a real necessidade de apontar o dirigismo constitucional na presente dissertação. Tendo como foco o entendimento da preservação e estímulo ao mercado interno na Constituição Brasileira de 1988 sob o ponto de vista de vários autores e recortes jurídico-teóricos, o presente estudo poderia estar circunscrito apenas ao seu objetivo geral - a análise dos discursos constitucionais acerca da defesa e promoção do mercado interno configurado como patrimônio nacional, referido no artigo 219 de nossa Carta.

Mas, para cumprir a tarefa suscitada, faz-se necessário preceituar quais são as premissas basilares de nosso objeto de estudo.

O desenvolvimento econômico é processo, e não simples ato isolado. Se no texto constitucional de 1988 há a previsão de um processo de desenvolvimento, deve-se observar qual é o conteúdo dos dispositivos que tratam do tema. Focando no objeto de estudo da presente dissertação, visto que o artigo 219 prevê que o mercado interno deva ser protegido

\footnotetext{
${ }^{17}$ CANOTILHO. José Joaquim Gomes. Constituição dirigente e vinculação do legislador. 2a edição. Coimbra: Coimbra Editora, 2001, pgs. XXIX-XX.

${ }^{18}$ Como as de Manoel Gonçalves Ferreira Filho, em: FERREIRA FILHO, Manoel Gonçalves. Princípios fundamentais de direito constitucional. 2a edição. São Paulo: Saraiva, 2010, p. 31.

${ }^{19} \mathrm{Cf}$. BERCOVICI, Gilberto. A problemática da constituição dirigente: algumas considerações sobre o caso brasileiro. In. Revista de Informação Legislativa, no 142, abr./jun. 199, p. 36.
} 
e estimulado para o desenvolvimento econômico e social da nação, faz-se necessário entender quais são as premissas teóricas que permitem (ou condicionam) que um texto constitucional possa efetivamente conter tais dispositivos.

Em outras palavras, antes de tentar compreender qual seria o significado do artigo, faz-se necessário entender quais são as origens teóricas que sustentam o seu conteúdo. Para analisar o que significa o dispositivo, é necessário antes de tudo entender qual o significado da presença das chamadas normas-objetivo na Constituição Federal de 1988.

Tudo isso porque o contexto da defesa do mercado interno está inserido em outro, mais amplo. A caracterização do mercado interno brasileiro junto ao patrimônio nacional e a necessidade de sua promoção é parte de um modelo de desenvolvimento econômico, que será devidamente apontado no capítulo 2 desta dissertação.O desenvolvimento econômico é um processo, basicamente fundado na premissa de que um Estado deve sair de determinada situação econômico-social e chegar à outra, necessariamente melhor que a anterior. Nas palavras de François Perroux, o desenvolvimento pode ser definido como " $l a$ combinaison des changements mentaux et sociaux d'une population qui la rendent apte a faire coître, cumulativement et durablement, son produit réel global” 20.

É a partir desta premissa que surge a necessidade dos apontamentos sobre o dirigismo constitucional. Como se verá nas linhas abaixo, a ideia de constituição dirigente de Canotilho está calcada na noção de que a constituição de determinado país contém dispositivos que não são apenas "garantias do existente, mas também um programa para o futuro $^{21 "}$. Logo, a tese do constitucionalismo dirigente perpassa a ideia central da "mudança social pelo direito." 22

A transformação social que o texto dirigente presume possui várias faces. Dentre as muitas, há de se observar a transformação econômica, ou seja, o desenvolvimento econômico.

\footnotetext{
${ }^{20}$ A combinação de mudanças mentais e sociais de uma população que a tornam adequada para crescer, cumulativamente e de forma permanente, seu produto real global. In PERROUX, François. L'economie du XXè Siécle, 2a edição, Presses Universitaires de France, Paris, 1965, p. 155.

${ }^{21}$ BERCOVICl. Gilberto. Constituição Econômica e Desenvolvimento. São Paulo: Malheiros, 2005, p.35.

${ }^{22}$ Idem ibidem.
} 
Por isso, aos nos depararmos com o estudo de um artigo que compõe um determinado modelo de desenvolvimento, faz-se necessário entender em que contexto constitucional tal dispositivo está inserido. Mais ainda, a proposição de que há um projeto de desenvolvimento nacional baseado na defesa do mercado interno ganha solidez ao conformar-se com a tese de que a Constituição ora analisada é em si um programa para o futuro.

\subsubsection{Constituição dirigente: a realidade enquanto tarefa.}

O problema de pesquisa da presente dissertação leva em conta a possibilidade da Constituição Federal de 1988 prescrever em seu texto um determinado modelo de desenvolvimento.

A confirmação desta ideia possui respaldo dentro da própria teoria constitucional. Conforme veremos, há forte corrente teórica que entende que o texto magno é conformado dentro de um tipo de constituição, a constituição dirigente.

Desta forma, antes de prosseguirmos na investigação sobre o modelo desenvolvimentista previsto em nossa constituição, ordenaremos que tipo de constituição tratamos. Ver-se-á adiante que, ao que servirá a esta pesquisa, estão certos os que defendem tratar nossa constituição de uma legítima constituição dirigente.

\subsubsection{A constituição dirigente de Peter Lerche}

O surgimento do termo "constituição dirigente" não pertence, de fato, a José Joaquim Gomes Canotilho. Idealizado originalmente por Peter Lerche, o conceito original era mais limitado, tanto em seu substrato teórico quanto à sua esfera de aplicação.

A dirigierende Verfassung de Lerche em muito se diferenciava do que fora proposto pelo jurista português. Conforme aponta Bercovici,

\footnotetext{
“ao utilizar a expressão "Constituição Dirigente, Peter Lerche estava acrescentando um novo domínio aos setores tradicionais existentes nas Constituições. Em sua opinião, todas elas apresentavam quatro partes: as linhas
} 
de direção constitucional, os dispositivos determinadores de fins, os direitos, garantias e repartição de competências estatais e as normas de princípio" 23

É o que aponta também Canotilho. Para Lerche, as diretivas constitucionais (Verefassungdirektiven) estariam divididas em três categorias: as normas programáticas (Programmasätze); as ordens constitucionais (Verfassungbefehle) e as imposições constitucionais (Verfassungsaufträge). As primeiras prescreveriam ao legislador uma determinada orientação no sentido de este desenvolver uma atividade de aproximação dos fins materiais por ela prescrito, ou na expressão de Canotilho, se configurariam como "pontapés de saída" que permitiriam ao legislador espaço para conformação dos "bens constitucionais" previstos.

Já as ordens constitucionais seriam os dispositivos que comprometeriam o legislador a realizar determinada tarefa. Conforme aponta Canotilho, Lerche apontava as ordens constitucionais como sendo os dispositivos que elencam determinadas tarefas, como por exemplo, a tarefa de regulamentação legislativa em face do dispositivo constitucional.

Entretanto, é a terceira categoria de dispositivo constitucional em que Lerche identifica o conteúdo dirigente de uma constituição. São os dispositivos de imposição constitucional que permeiam a conceituação topográfica de uma constituição dirigente. Dividindo as diretivas constitucionais elencadas como imposições constitucionais entre imposições que se dirigem á realização-complementação da constituição e regras diretivas formais de caráter contínuo, o autor alemão preceitua à essa segunda espécie de imposições constitucionais a categoria de constituição dirigente. ${ }^{24}$

Desta feita, vê-se que para Lerche, a constituição dirigente é na verdade um segmento do texto constitucional. É, por assim dizer, aquele conjunto de normas e princípios que juntos constituem um conjuntos de diretivas formais de caráter contínuo, onde não há espaço para atuação diversa do legislador se não cumprir o que está textualmente previsto na constituição. Como se verá adiante, em que pese a desconexão entre as proposições de

\footnotetext{
${ }^{23}$ BERCOVICl, Gilberto. Constituição econômica e desenvolvimento. Op. cit. p. 34.

${ }^{24}$ CANOTILHO. José Joaquim Gomes. Constituição dirigente e vinculação do legislador. Coimbra: Coimbra Editora, 1a edição, 1982, p. 310.
} 
Lerche e Canotilho, ambos terminam por “desconfiar' do legislador na medida em que procuram imbricar a regulamentação infraconstitucional à um determinado programa.

Se para o constitucionalista alemão o texto dirigente de determinada constituição se resumiria a partes da lei maior de determinada nação, para o jurista português, a noção de texto dirigente será bastante diferente. É sobre o que se discorrerá a seguir.

\subsubsection{Canotilho e sua constituição dirigente.}

José Afonso da Silva aponta em seu Aplicabilidade das Normas Constitucionais, que o sociologismo constitucional se funda em ao menos quatro premissas dentre elas, ressalta a ideia de que a Constituição de um país é "primordialmente a expressão de ser, e não de dever-ser"

Respalda-se o brasileiro no sentido de um texto constitucional ser a expressão dada de determinada realidade político-jurídica. A Constituição é enquanto produto do real social que a conforma e não um texto que deve ser. Sob a ótica do sociologismo constitucional, a constituição é a expressão do ser de um determinado corpo social.

Tal concepção vai ao encontro direto da proposição de Canotilho sobre o que seria uma constituição sob a ótica dirigente.

Para o constitucionalista lusitano, a constituição dirigente é antes de tudo o elemento vinculante ao legislador para o cumprimento dos fins e objetivos nela previstos. Assim, o autor diferencia de plano a ideia de Constituição Aberta, da Constituição Dirigente. Para Canotilho, trata-se de diferenciar as ideias: "a constituição não é só uma 'abertura para o futuro' mas uma tarefa normativo material, um projeto material vinculativo, cuja concretização se 'confia' aos órgãos constitucionalmente mandatados para o efeito." 26

\footnotetext{
${ }^{25}$ SILVA, José Afonso da. Aplicabilidade das normas constitucionais. 7ạ Edição. São Paulo: Malheiros, 2007, p.22

${ }^{26}$ CANOTILHO. José Joaquim Gomes. Constituição Dirigente e Vinculação do Legislador, 1a edição. Op. cit. p. 307
} 
Em outras palavras, o autor de aponta que a ideia fundante de uma constituição sob o estigma de sua teoria, estaria comprometida em atuar transformando a realidade.

De fato, já no início de sua obra, o autor se preocupa em, ao diferenciar a tese dirigente das teses de "constituição da liberdade" ou a constituição como "instrumento de governo", determinar que não se trata "de um mero retorno a uma concepção ontológico-metafísica ou operar uma simples transferência da problematização da conformação da metafísica ontológica para a subjetividade transcendental ${ }^{27,}$.

É a noção de que para um texto constitucionalmente dirigente, a realidade é a tarefa a ser realizada. Perpassa-se, através da concretização vinculada de suas normas, de um estágio de coisas a outro. As ações do Estado, não só dentro do Poder Executivo, mas principalmente dentro da esfera Legislativa, devem traduzir em realidade as previsões inseridas na constituição ${ }^{28}$.

As próprias palavras do jurista lusitano apontam para este sentido. Logo ao início de sua tese, o autor prima em conceituar o debate sobre "o que deve (e pode) uma constituição ordenar aos órgãos legiferantes e o que deve (como e quando deve) fazer o legislador para cumprir, de forma regular, adequada e oportuna, as imposições constitucionais"29.

Tudo porque a operacionalização do sistema jurídico-constitucional de uma nação é muito mais complexa do que se vê à primeira vista. A própria manutenção da hierarquia da Constituição sobre todo o ordenamento jurídico nacional é, como lembra Canotilho, inserida em um complexo problemático muito mais vasto.

Tal complexidade, aponta, reside basicamente em dois planos: o plano teoréticoconstitucional e o plano teorético-político.

\footnotetext{
${ }^{27}$ CANOTILHO. José Joaquim Gomes. Op. cit. p. 71.

${ }^{28}$ No trabalho apresentado por Canotilho e que aqui será exaustivamente citado, a preocupação do autor se foca não apenas em apontar o sentido de uma constituição dirigente. Sua tese se preocupa também em inserir a vinculação do legislador à norma constitucional. A presente dissertação, pelo contrário, só se debruçará sobre a primeira problematização apresentada.

${ }^{29}$ CANOTILHO. José Joaquim Gomes. Op. cit., p. 11
} 
Deveria a constituição ser concebida apenas como "estatuto organizatório" do Estado, como expõe Canotilho? Deve a constituição de um país se conformar enquanto instrumento governamental, definindo competências e regulando processos? Ou pelo contrário, deve a carta constitucional se embrenhar dentro de discussão mais ampla, aspirando se transformar "num plano normativo-material global que determina tarefas, estabelece programas e define fins? ${ }^{30,}$

Trata-se de discutir se uma constituição é apenas uma lei do Estado e só do Estado ou é “um 'estatuto jurídico do político', um 'plano global normativo' do Estado e da sociedade? , 31

A tese de Canotilho sobre o dirigismo constitucional evita o reducionismo simplista de terse um objeto de estudo como texto estático, descolado do real. É com o objetivo de impedir a simples "jurisdicização da sociedade constitucional" que está sustentada a tese dirigente. Tenta com isso prevenir a abstração de problemas fundamentais de ordem teoréticopolíticas, tais como a questão da legitimação e domínio de tal sociedade, procurando integrar direito e política.

Aprofunda o autor tais temas, assinalando que a ideia de constituição dirigente imbrica-se na senda da constituição-programa, sendo considerada como introversão no modelo “constituição-garantia". Melhor dizendo, a discussão sobre uma agenda política para a constituição pode ser considerada como uma afronta ao que se pode chamar de uma “primeira geração constitucional”, resultante da aplicação dos ideais iluministas, cuja expressão mais influente no novo mundo talvez seja a Constituição dos Estados Unidos da América. $^{32}$

As constituições do século XVIII fundaram-se na instituição do Estado de Direito, destituindo o poder monárquico e estabelecendo, principalmente, limites à atuação do Estado e um mínimo de garantias aos cidadãos de determinado país. As chamadas “constituições-garantias" visavam muito mais solidificar, sob o ideário liberal dos séculos XVIII e XIX, um Estado de Direito do que qualquer outra coisa. Como aduz Canotilho,

\footnotetext{
${ }^{30}$ Idem ibidem, p. 12.

${ }^{31}$ Idem ibidem, p. 12

${ }^{32}$ Idem ibidem, p. 12.
} 
eram as constituições que se organizavam em torno da lógica de "garantir as regras do jogo". Não deveriam (como até hoje não devem) suceder nenhuma outra espécie de "intromissão" na ordem jurídico-política da nação que não seja a imposição de limites à atuação do Estado em todas as suas formas como também instituir um rol de direitos e garantias do cidadão, seja em face do próprio Estado, seja em face de um cidadão em relação à sua coletividade. Trata-se, portanto de importante passo político para os povos, que viu no individualismo liberal um ponto de partida para outra proposta de organização social.

Do outro lado, apontam-se as chamadas constituições-programa.

Se o final do século XVIII e o início do século XIX marcaram o surgimento de textos constitucionais que são apontados pela doutrina como as chamadas constituições-garantia, o segundo quartel do século XIX em diante viu a proliferação de um número bastante razoável das chamadas constituições sociais. Frutos do alargamento dos direitos políticos e sociais vistos ao longo do século XIX por toda a Europa, tais constituições, são “consideradas parte do novo 'constitucionalismo social' que se estabelece em boa parte dos Estados europeus e em alguns americanos. ${ }^{33}$,

É dentro do universo das constituições sociais que se encontram as chamadas constuiçõesprograma. Com a expansão do rol de direitos previstos em tais cartas, que passam agora a contar com os chamados direitos sociais, começam a surgir pressões sociais para a implementação de tais direitos. Em maior ou menor medida, a efetivação das novas garantias sociais irá perpassar pela atuação direta do Estado. Ou seja, a efetivação dos direitos políticos, econômicos e sociais que começam a ser abarcados nas novas cartas constitucionais conformarão a necessidade de ação estatal, visando colocar em prática aquele conjunto de novos direitos. Ao processo de implementação, conformar-se-á um programa de ação para todos os entes públicos. Daí o termo constituição-programa.

Talvez um dos melhores exemplos deste segundo modelo seja a Constituição de Weimar, de 1919. Conforme aponta Bercovici, o texto de Weimar é "frequentemente denominado

\footnotetext{
${ }^{33}$ BERCOVICl, Gilberto. Constituição econômica e desenvolvimento. São Paulo: Malheiros, 2005, p.11.
} 
como 'compromisso constitucional' (Verfassungskompromiss), ou 'constituição programática", 34 .

A importância desta discussão está obviamente ligada ao entendimento do que é a Constituição-programa e sua importância para a conceituação de uma constituição dirigente. Desta forma, observa-se que a noção de um dirigismo constitucional funda-se na lógica de um texto programático, que estabeleça conteúdo de direcionamento político ao Estado, saindo de uma simples constatação inerte da existência de obrigações, direitos e garantias para outro estágio, que conforma regras de atuação para o poder público.

Tal conformação de regras sé dá pela instituição das chamadas normas programáticas $35 ; 36$ ou normas-objetivo ${ }^{37}$. Assim, para prosseguirmos na conceituação da constituição dirigente, faremos explanação à parte para o melhor entendimento das chamadas normas programáticas.

\subsection{O conceito de normas programáticas.}

Primeiramente, há de se diferenciar aqui o conceito utilizado. Para efeitos desta dissertação, a ideia de dispositivo programático é o apontado por Eros Grau como sendo normas-objetivo. Conforme coloca o autor, a norma-objetivo "não define nem conduta nem organização. Determina, fixando-os, fins a serem alcançados. Fixa objetivos." 38

Ou seja, para esta dissertação o conceito de norma programática pode ser entendido como a norma - no caso um artigo constitucional - que impõe à Administração um objetivo, um ponto de chegada para a ação do Estado. É uma espécie de vinculação entre a ação estatal e o resultado almejado, em relação àquele tema que o artigo trata.

\footnotetext{
${ }^{34}$ BERCOVICl, Gilberto. Constituição e estado de exceção permanente: atualidade de Weimar. Rio de Janeiro: Azougue Editorial, 2004, p.27.

${ }^{35}$ Conforme aponta MIRANDA, Jorge. Manual de Direito Constitucional, Tomo II. Coimbra: Coimbra Editora, 5a Edição, 2003, pgs. 270 a 274.

${ }^{36}$ Ver ainda SILVA, José Afonso da. Op. cit., p. 135

${ }^{37}$ Conforme GRAU, Eros. Notas sobre a noção de norma-objetivo, in Revista de Direito Público no 71 . São Paulo: Editora Revista dos Tribunais, p. 137 e seguintes.

${ }^{38}$ GRAU. Eros. Direito, conceitos e normas jurídicas. São Paulo: Revista dos Tribunais, 1988, p. 132.
} 
Assim, o termo é aqui utilizado em referência às constituições programáticas, que são aquelas que possuem em seu texto um programa definido para o Estado. Em mais uma referência a Eros Grau, o conceito aqui apreendido de normas programáticas, semelhante ao de norma-objetivo, está ligado à ideia de "instrumentos normativos que operam a transformação de fins sociais e econômicos em jurídicos." 39

Produtos de uma transformação técnico-política, os dispositivos programáticos estão intimamente ligados às mudanças ocorridas principalmente nos países europeus ao final do século XIX. Conforme o modelo estatal tipicamente liberal começa a ser alterado pelos avanços sociais garantidos ao longo do século XIX e início do século XX, alteram-se também as previsões constitucionais relativas às tarefas e deveres do poder público.

Em verdade, as novas demandas sociais não aparecerão imediatamente no plano constitucional, muito menos serão abarcadas de início como obrigações do Estado. Ao longo do último quartel do século XIX, solidificar-se-ão aos poucos os direitos sociais, e com eles as pressões por sua realização. É neste cenário que as pressões de partidos políticos e movimentos contrários ao status quo liberal da Europa imputarão nas novas cartas constitucionais tais direitos.

A consequência lógica da ampliação do rol de direitos garantidos aos cidadãos nas novas cartas constitucionais emergentes será a cobrança pela concretização de tais direitos. Assim, a metamorfose constitucional que o início do século XX observará dará conta não apenas de garantir novos direitos (os direitos sociais) como também o caminho para realizá-los.

É neste cenário que as constituições absorverão as chamadas normas programáticas, ou normas-objetivo. Definidas por Pontes de Miranda como "aquelas em que o legislador, constituinte ou não, em vez de editar a regra jurídica de aplicação concreta apenas traça linhas diretoras, pelas quais se hão de orientar os Poderes Públicos" ${ }^{40}$, são talvez os

\footnotetext{
${ }^{39}$ Idem ibidem, p. 152.

${ }^{40}$ PONTES DE MIRANDA, Francisco Cavalcanti. Comentários à Constituição de 1967. São Paulo: Editora Revista dos Tribunais, 1968, t. I, p. 126 e 127.
} 
dispositivos que constituem "o campo onde mais fluidas e incertas são as fronteiras do Direito com a Política." 41

Sem se desfazer da importância da absorção pelas constituições nascidas no século passado, Paulo Bonavides ainda ressalta o fato de que a fragilidade de tais normas talvez seja o maior motivo de sua não concretização, dada a dúvida implícita à sua eficácia e juridicidade. Em que pese não compartilhar das teses de Schmitt sobre as normas programáticas na forma de compromissos dilatórios, alerta o autor para o fato de que a vagueza textual, implícita a tais normas, pode inviabilizar sua concretização.

Como será exposto mais a frente, as implicações práticas dos dispositivos programáticos resvalarão na própria constituição dirigente. Talvez o maior problema das leis fundamentais erigidas sob tal forma, nas palavras de Canotilho, seja o problema da legitimidade.

Retomando os debates sobre o conceito de normas programáticas, há de se observar a polissemia do termo. Independentemente das questões relativas à sua eficácia, é fato que as normas programáticas foram definidas de diferentes formas ao longo da doutrina constitucional, nacional ou estrangeira.

Jorge Miranda, jurista português, aponta que não há diferença de natureza ou valor entre as normas programáticas e o que chamou de normas perceptivas. Focando-se nas normas programáticas, o autor enumera várias características das chamadas normas programáticas. É então, a partir de tais características, que Miranda vai indicar o conceito de tais normas.

Além de ressalvar que elas fazem-se presentes ao longo das chamadas constituições sociais do século XX e XXI, o autor afirma que tais dispositivos resultam da dilatação de outros

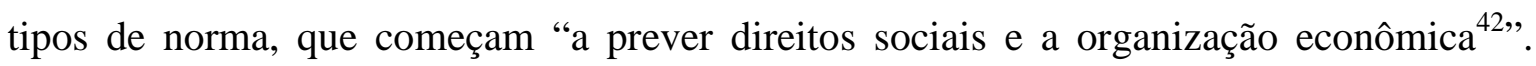
Desde então, garante Jorge Miranda que tais dispositivos programáticos estarão presentes em largo número nas constituições contemporâneas.

\footnotetext{
${ }^{41}$ BONAVIDES. Paulo. Curso de Direito Constitucional. São Paulo: Malheiros, 24a Edição, 2009, p.245.
}

42 MIRANDA, Jorge. Manual de Direito Constitucional. Op. cit, p. 273 
Dentre as inúmeras características apontadas por Miranda, destaca-se que as normas programáticas definem-se: por serem de aplicação diferida, e não de aplicação ou execução imediata; por prescreverem obrigações de resultado - e não de meio; e, por terem como destinatário primacial - embora não único - o legislador. ${ }^{43}$

Conta-se ainda com a definição de José Joaquim Gomes Canotilho sobre o que seriam as ditas normas programáticas. Aponta o jurista que são as normas que contém a ideia de que "não sejam autêntico direito atual, de imediata aplicabilidade, como linhas programáticas dirigidas ao legislador e não como autênticas normas jurídicas imediatamente preceptivas e diretamente aplicáveis pelos tribunais ou quaisquer outras autoridades". ${ }^{4}$

A problematização das consequências da previsão constitucional de tais normas será colocada adiante. Como será demonstrado, o problema a ser superado por Canotilho conquanto a existência de tais dispositivos se dá no plano da eficácia constitucional. Será ao travar o debate sobre as imposições constitucionais que Canotilho abordará os revezes do conteúdo programático dentro da efetivação das constituições dirigentes.

Outra definição que merece ser apontada, apenas a título de referência, é a exposta por José Afonso da Silva. Para o autor, podemos entender normas programáticas como:

\begin{abstract}
"normas constitucionais através das quais o constituinte, em vez de regular, direta e imediatamente, determinados interesses, limitou-se a traçar-lhes os princípios para serem cumpridos pelos seus órgãos (legislativos, executivos, jurisdicionais e administrativos), como programas das respectivas atividades, visando à realização dos fins sociais do Estado.
\end{abstract}

O constitucionalista informa que as normas programáticas seriam parte de outro grupo, as normas de eficácia limitada. Para o autor, são normas de eficácia limitada "aquelas que

\footnotetext{
${ }^{43}$ Idem ibidem, p. 272

${ }^{44}$ CANOTILHO. José Joaquim Gomes. Direito Constitucional e teoria da Constituição. 7ạ Edição. Coimbra: Livraria Almedina, 2003, p.177.

${ }^{45}$ SILVA, José Afonso da. Aplicabilidade das normas constitucionais. Op. cit., p. 138. Ressalta-se aqui que o conceito apreendido por José Afonso da Silva sobre a ideia de norma programática difere por completo do aqui utilizado. A ideia do constitucionalista aponta para uma norma carente de interpretação imediata. Essa discussão guarda relação com as proposições de Carl Schmitt, que as intitulava de "compromissos dilatórios". Conceituava o autor que tais dispositivos seriam frutos das disputas políticas ao longo do processo constituinte. Dada a disputa, seria impossível determinar uma vontade existente, pois, como afirmara Schmitt, "nestes dispositivos, a única vontade é a de não ter, provisoriamente, nenhuma decisão naquele assunto. Para mais informações, vide: BERCOVICl, Gilberto. Constituição e estado de exceção permanente. Op. cit, p. 31.
} 
dependem de outras providências para que possam surtir os efeitos essenciais colimados pelo legislador constituinte." 46

Como foi possível observar, há uma gama diversa de conceitos sobre as chamadas normas programáticas. Porém, em que pese esta considerável quantidade de apontamentos sobre as referidas, é possível apontar, com alguma precisão, que tais dispositivos se conformam como imposições mediatizadas, seja pela necessidade de concretização via regulamentação posterior, seja pela necessidade de ação de agentes do Estado para sua realização. Entretanto, como indica Jorge Miranda, a execução legal das normas programáticas pode ser encarada como um espaço de lacuna legis, porém, jamais de lacuna juris. ${ }^{47}$

Outro apontamento que merece destaque aqui é a conformação das ditas normas programáticas dentro da constituição dirigente. Como foi dito, o texto programático, em si carregado de necessária vagueza, não será empecilho para a realização dos textos dirigentes. É fato, como já fora citado anteriormente, o formulador da teoria do dirigismo constitucional impõe à realização da constituição a necessidade de sua legitimação. Como se verá a seguir, sem tal realização será impossível a concretização dos dispositivos programáticos, implicando na não realização da chamada constituição dirigente.

\subsubsection{O problema da legitimação-legitimidade na constituição dirigente.}

A questão da legitimação não é, na verdade, um problema específico da constituição dirigente. Sabe-se que a discussão sobre legitimação e legitimidade legislativa e, mais especificamente, constitucional, é um problema sob o qual se debruçaram inúmeros pesquisadores do direito.

Perpassando a discussão sobre a própria legitimação do Estado, a discussão sobre quais seriam os principais sustentáculos que legitimariam a existência e a "justificação da existência de um 'poder' ou 'domínio' sobre os homens e a aceitação deste domínio por parte destes" 48 das constituições é, há muito, problemática dentro das pesquisas em direito constitucional.

\footnotetext{
${ }^{46}$ Idem ibidem, p. 118.

${ }^{47}$ MIRANDA. Jorge. Manual de Direito Constitucional. Op. cit., p. 274.

${ }^{48}$ CANOTILHO. José Joaquim Gomes. Constituição Dirigente e Vinculação do Legislador. Op. Cit, p. 15.
} 
Na verdade, tal questão, como lembra Canotilho, está ligada à legitimação-legitimidade do próprio Estado. Até porque a constituição é, antes de tudo, o paradigma organizacional do Estado. Assim, o debate sobre legitimação e legitimidade do Estado é imbricado às discussões de idêntico valor, sobre as cartas constitucionais.

Nesta esteira, torna-se necessário que se assevere algumas linhas sobre a importância da discussão na presente pesquisa.

1.3.2.3.1. Implicações do debate sobre legitimidade e legitimação na presente dissertação.

Antes que se discorra sobre a questão aventada, vale a pontuação da importância deste debate para a pesquisa que aqui se inicia.

A questão da legitimação-legitimidade na constituição dirigente é, como lembra o constitucionalista português, mais que um mero "debate filosófico". Para as teses da constituição dirigente e para esta dissertação em específico, demonstrar que um dos pontos chaves da teoria de Canotilho - que é a questão da legitimação e da legitimidade -importa em apontar tanto sobre a legitimação da existência da constituição quanto à viabilidade da concretização de tal texto. Melhor dizendo, se a soberania da ordem jurídica já é de importância fundamental naqueles ordenamentos cuja constituição seria um texto de matriz garantidora (as constituições-garantia), há de se pensar qual é o grau de importância que tal discussão assume dentro de um espectro dirigente.

Se a manutenção de uma ordem jurídica está completamente atrelada à existência de uma legitimidade desta mesma ordem - e em especial de sua constituição - o que se dirá das ordens jurídico-constitucionais cuja constituição é uma constituição dirigente? Dada a natureza de tais constituições, a de transformar via ações do Estado a realidade existente, como justificar, no plano constucional-normativo a consecução das tarefas e fins do próprio Estado-dirigente? No caso da presente pesquisa, de onde nasceria a justificativa para a sustentação da manutenção do mercado interno enquanto patrimônio nacional? 
A resposta de tais questionamentos está, como se sabe, ligada à legitimação-legitimidade do próprio texto constitucional. Sabe-se que a demanda por tal discussão é muito maior do que esta dissertação comporta. Entretanto, dada a natureza e importância do debate, tornase impossível que se feche uma definição minimamente razoável sobre a constituição dirigente - que ao que tudo indica, é a atual Constituição brasileira - sem que se discorram algumas linhas sobre o tema.

As implicações deste debate resvalam na concretização dos dispositivos programáticos previstos em um texto constitucional dirigente. Para realizar os textos programáticos como, por exemplo, o dispositivo constitucional ora estudado, há de se entender quais são os entraves e questionamentos ao que Canotilho chamara de necessidade de dinamização do texto constitucional.

Portanto, debater este ponto, ainda que com profundidade relativa, é fundamental para que se compreendam quais sejam as possíveis significações presentes dentro do debate sobre o mercado interno no texto constitucional de 1988, inserido junto ao seu artigo 219.

\subsection{Legitimação-legitimidade da Constituição Dirigente e uma teoria da constituição constitucionalmente adequada}

Dentro do esforço teórico empreendido por Canotilho encontra-se a necessidade de apontar os rumos para o que chamou de teoria da constituição constitucionalmente adequada.

Tudo porque, como aponta o jurista lusitano, as inserções de funções programáticas e a introdução de fins político-econômicos às constituições constituíram um "esforço positivo para reforçar a própria legitimidade constitucional" 49 . Isto, porém, implicaria em uma sensível revisão de uma teoria constitucional que para ser, segundo ele, constitucionalmente adequada, deveria estar incumbida de investigar, justificar ou criticar a sociologização do direito constitucional que acompanha ou pode acompanhar a programática constitucional.

${ }^{49}$ CANOTILHO, José Joaquim Gomes. Constituição dirigente e vinculação do legislador. Op. cit., p. 157. 
Para Canotilho, como ressalta Bercovici, "o texto constitucional é o texto que regula uma ordem histórica concreta, e a definição da Constituição só pode ser obtida a partir de sua inserção e função na realidade histórica" ${ }^{\natural 0}$. Assim, quando uma constituição assume a realidade como tarefa, e se a realidade não é ordem fixa e fechada, vê-se que

\begin{abstract}
"uma constituição democrático-republicana não se compadece com reduções unidimensionalmente integracionistas, antes se abre à polaridade do social e às contradições e antagonismos que determinam na substância e no processo, a realidade ideal e material" ${ }^{51}$
\end{abstract}

Talvez a principal questão que envolva a necessidade de uma teoria da constituição constitucionalmente adequada para o caso da constituição dirigente seja, como aponta o próprio autor, a necessidade de responder "às exigências de legitimação de uma ordem constitucional, historicamente situada." 52

É então que surge de fato a discussão sobre a legitimação-legitimidade na constituição dirigente.

A problemática aportada por Gomes Canotilho surge, segundo ele, pela própria dinamização da constituição. Ao expressar linhas de direção que tendam a sujeitar os órgãos de direção política à execução de imposições constitucionais, nasce o que seria para ele, o problema da legitimação.

Ou seja, para o jurista a questão da legitimação brota como o problema central da constituição dirigente:

\footnotetext{
"a conformação social, a distribuição de bens e a direção do processo econômico deslocam a questão da legitimidade da ordem constitucional e da validade do direito constitucional para o campo da legitimação do 'capitalismo tardio', do 'reformismo' e do 'socialismo', vindo, assim, a entroncar nos debates sobre o Estado e a 'produção da sociedade", 53
}

Observa-se que a questão da legitimação não está mais, nas constituições dirigentes, circunscrito aos limites das teorias constitucionais que limitam a lógica da legitimação pelo

\footnotetext{
${ }^{50}$ BERCOVICl, Gilberto. A problemática da constituição dirigente: algumas considerações sobre o caso brasileiro. IN Revista de Informação Legislativa. Ano XXXVI, no 142 abr./jun. 1999, p. 35

${ }^{51}$ CANOTILHO, José Joaquim Gomes. Op. Cit., p.156.

52 Idem ibidem, p. 156.

53 Idem ibidem, p. 24.
} 
que chama o autor de lógica obrigatória da 'ideia de direito’ que “é ainda uma lógica do absoluto e do transcendente" ${ }^{, 54}$.

Nesta linha, o que se observa é que o autor parte, primeiramente, da ideia de conformação da sociedade em um determinado momento histórico. Nas palavras de Gomes Canotilho, trata-se de um "problema aberto" constitucional está também na inclusão social do direito material.

Desta forma, ao invés de simplesmente buscar inserir a teoria da constituição constitucionalmente adequada dentro do foro da História, cuida para que "[E]m vez de se colocar a 'historicidade no direito, seria talvez mais correto colocar o direito na 'sociedade","56.

Esta transposição incide também em captar a demanda social que se transfigura no próprio texto constitucional. A transposição do imaginário social dentro da constituição se dá em seu próprio texto programático. Como já apontou o autor, a constituição dirigente só terá sentido quando considerar a realidade como tarefa.

Tudo porque - na opinião do jurista português - é um dado da realidade a "irredutível dualidade" que marcam as discussões constitucionais, entre a ideia de sociedade civil e liberdade individual (transfigurada no conceito de "mercado") em oposição à ideia de um todo social e igualdade, representada pelo conceito de "Estado". ${ }^{57}$

Esta dualidade imobilizadora seria incapaz de dar conta do problema aberto que é de fato a conformação social. Por isso adota como pressuposto a noção de que o estudo do texto constitucional não deverá ser uma mera apuração de "uma ontologia do 'ser do Estado' ou do 'ser do mercado' e considerar esses dois 'seres' como 'pontos' e 'limites' absolutos". 58

\footnotetext{
${ }^{54}$ Idem ibidem, p. 16.

${ }^{55}$ Idem ibidem, p; 70.

${ }^{56}$ Idem ibidem, p. 16. Completa ainda, citando Alain Tourraine, que se deve, por consequência, colocar a historicidade no "coração" da sociedade, de uma sociedade que se produz.

${ }^{57}$ Para esta discussão na obra de Canotilho, vide: CANOTILHO, José Joaquim Gomes. Constituição Dirigente e Vinculação do Legislador, op. cit., p. 69.

58 Idem ibidem, p. 70.
} 
A análise suscitada leva então a crer que o texto constitucional dirigente não pode ser considerado sob uma ótica estática tradicional e reducionista, onde há de se defender a tese de pró-Estado ou pró-mercado em si. Ou seja, não se trata em inserir a Constituição em determinado estigma e sob tal, analisá-la. Para compreender as dimensões destes dois campos dentro da constituição, há de se considerá-los “dentro de um processo dialético em que o problema da constituição social é um problema de transformação da realidade a realizar pelos homens". 59

É este processo dialético que será o ente conformador da legitimidade dos dispositivos programático-dirigentes previstos em tais textos constitucionais. Percebe-se que ao entender a chamada conformação social como um processo real-objetivo, o autor traça o que será o sustentáculo de legitimidade do modelo constitucional aventado.

É possível apreender que, para Canotilho, a dificuldade central da legitimidade das constituições - e principalmente nos textos dirigentes - reside em "reconduzir-se à explicação dos fundamentos da dignidade de reconhecimento e uma ordem constitucional, através da fixação dos fins e tarefas que incumbem ao Estado",60,

Em outros termos, a legitimidade do texto constitucional dirigente advém do entendimento de que o direito não é legítimo em si. Adotar tal postura é transcendentalizar a discussão proposta. Sugere Canotilho que a legitimidade do direito em geral e da constituição dirigente em particular estariam assentados em uma "teoria do direito constitucional empírico, na medida em que 'revelasse' como a legitimação se desenvolveu, numa perspectiva histórica, ancorada em 'práticas' juridicamente 'reguladas'.,"61

\footnotetext{
${ }^{59}$ Idem ibidem, p. 70. É interessante notar que a principal crítica feita à tese da constituição dirigente reside na ideia de este modelo constitucional seria demasiadamente estatizante e buscaria, por fim, o socialismo. Aparte da clara demonstração de que os processos são mais dialéticos e abertos (como apontou o autor) restam ainda as críticas feitas pelo próprio Canotilho em artigo publicado no Brasil em 1996. Em seu Rever ou Romper com a Constituição Dirigente: em defesa de um constitucionalismo moralmente reflexivo, Gomes Canotilho aponta para o fato de que a imputação de seu à doutrina social-comunista é distorção dos fatos, ou melhor, uma inaceitável transposição de planos. In CANOTILHO, José Joaquim Gomes. Rever ou Romper com a Constituição Dirigente: em defesa de um constitucionalismo moralmente reflexivo. Doutrinas Essenciais de Direito Constitucional, São Paulo: Editora Revista dos Tribunais. Tomo I, p. 117.

${ }^{60}$ Idem ibidem, p.473.

${ }^{61}$ CANOTILHO, José Joaquim Gomes. Op. cit., p17
} 
Nesta linha, o que é possível perceber é que a questão da legitimidade de uma constituição dirigente é operada na medida em que seus dispositivos dirigentes são efetivamente aplicados. Assim, para garantir a sobrevivência de uma constituição deste tipo é necessário que sejam colocados em prática os chamados dispositivos programáticos. Talvez seja por isso que, para o jurista, o caráter dirigente auxiliaria a própria constituição a se legitimar.

É por tudo isso que se torna impossível a redução da legitimidade da ordem constitucional apenas ao processo social que se procurará trilhar. Não basta apenas buscar legitimar a ordem constitucional sob o aspecto formal do Estado Constitucional. Como visto, é sob os aspectos materiais, imbricados na chamada teoria da constituição constitucionalmente adequada que residirá a legitimação das constituições dirigentes. É no âmago do processo dialético de conformação social que cria o texto constitucional que nascem os preceitos constitucionais programáticos, e é lá também onde reside parte da legitimação da constituição.

Ao ser produto social e não um dado extra-sociológico e metafísico que a constituição se legitima. Desta forma, e não de nenhuma outra, o programa previsto nas constituições insculpidas sob o signo do dirigismo é legitimo pelo processo que o cria e ao longo do processo que o executa.

De toda a discussão aqui impingida resta apontar os reflexos desta discussão no plano prático desta dissertação.

Ao buscar as origens da legitimidade do texto constitucional, forçou-se a reflexão não apenas sobre a legitimidade em si, mas também as raízes da própria teoria constitucional por trás da tese da constituição dirigente. Portanto, a análise hermenêutica deste tipo constitucional deve ser, conforme aponta Canotilho, procedida através da hermenêutica crítica, que não apenas insere o dispositivo analisado dentro de um contexto histórico, mas também social.

Esta proposição será parte do fio condutor desta dissertação. Com o fito de analisar o artigo 219 da Constituição Federal de 1988, procederemos uma avaliação histórica de dois dos principais discursos econômicos que disputaram o conteúdo da chamada constituição 
econômica da Constituição Brasileira. Como visto, parte importante da investigação dos sentidos previstos no dispositivo em análise perpassa pela compreensão do momento histórico-econômico que o país atravessava.

Assim, não apenas o entendimento, mas a própria legitimidade da defesa do mercado interno reside em compreender o processo dialético ao qual se referiu aqui. Isso não significa que a preposição de Canotilho beba das fontes originalistas da hermenêutica constitucional, pelo contrário. Visa o autor entender o momento histórico que a constituição está inserida para que se consiga entender de onde partiu o processo de legitimação do texto constitucional.

Entretanto, como fora por diversas vezes frisado aqui, o processo de legitimaçãolegitimidade se calca em um esquema dialético oriundo do movimento entre as forças sociais pró-Estado e pró-mercado. Como apontou o jurista português é um processo aberto onde o dirigismo se encontra não em congelar a análise da constituição sob os vieses da época em que foi promulgada.

Mais do que isso, a vinculação do legislador está imbricada neste processo que nunca é retilíneo ou homogêneo. Assim, não se trata de traçar de forma linear o que se entendia do texto à época de sua formulação e transplantá-lo à atualidade, mas de entender sob quais forças político-sociais o texto foi construído para que se entendam quais eram os fins e objetivos previstos na constituição. Não há de se vincular o entendimento constitucional, mas sim limitar a atuação do legislador.

Trata-se, portanto, de compreender as raízes político-sociais daquele momento histórico para que disso se extraia, dentro da realidade do presente, ações para o futuro.

\subsubsection{Constituição Dirigente: algumas críticas}

Ao longo de sua vida, a teoria da constituição dirigente sofreu - e ainda sofre - várias críticas. De conteúdo variado, os questionamentos sobre os alcances, origens, validade e orientação ideológica ganharam força ao longo de sua existência. Como veremos no próximo tópico, de fato o próprio formulador parece entender que não há mais tanto espaço 
para os processos de transformação social previstos nos textos constitucionais dirigentes. Ainda que costumeiramente mal interpretado em sua colocação sobre a morte da constituição dirigente, o fato é que Canotilho já não mais entende que os escritos de uma constituição possam ser suficientes para pavimentar os processos de mudança de um determinado tecido social.

Dentre as críticas mais pertinentes, aponta-se aqui o entendimento de Gilberto Bercovici, que noticia o que talvez seja o principal problema da teoria da constituição dirigente: a criação de uma teoria constitucional auto-suficiente, que favorece em muito o instrumentalismo constitucional, esvaziando da teoria da constituição sua ligação com a teoria do Estado. ${ }^{62}$

É o que chamou de uma constituição sem Estado, em uma situação que, corroborada com o processo de globalização econômica, "dessubstancializou" a própria constituição. Assim, a teoria da constituição dirigente seria uma teoria que, ao fim, se legitima como instrumento processual de conquista e manutenção de direitos, esquecendo-se do elemento democrático como sendo justificador da legitimidade. ${ }^{63}$

Entretanto, não são apenas as próprias críticas de Canotilho e de Bercovici que esgotam o arsenal de questionamentos sobre sua tese. Subsistem dentro daquelas construções que questionam a validade do dirigismo constitucional argumentos de força que foram em boa parte combatidos por Gomes Canotilho. Como veremos a seguir, as críticas se fundam basicamente em quatro eixos:

A) Quanto à discricionariedade legiferante do legislador infraconstitucional;

B) Quanto às imposições constitucionais sobre as tarefas e fins do Estado previstos no texto constitucional;

C) A problemática do direito diretamente aplicável, e;

D) As questões referentes às omissões constitucionais existentes em determinada constituição dirigente.

\footnotetext{
${ }^{62} \mathrm{BERCOVICI}$, Gilberto. A constituição dirigente e a crise da teoria da Constituição. In Teoria da Constituição. Estudos sobre o lugar da política no Direito Constitucional. Rio de Janeiro: Lumen Juris, 2003, p. 119 e 120.

${ }^{63}$ Idem ibidem, p. 121.
} 
Ao que nos interessa aqui, trataremos de basicamente dois dos quatro pontos levantados. Isso porque, além de não haver espaço hábil para o aprofundamento de todos os itens, interessam diretamente à pesquisa apenas dois dos itens: a discricionariedade legiferante do legislador infraconstitucional e as críticas sobre as imposições constitucionais referentes às tarefas e fins do Estado.

Sucintamente, expomos que a auto-aplicabilidade do direito previsto em determinado dispositivo dirigente é de interesse subsidiário a esta dissertação na medida em que os formuladores das teorias que darão suporte à análise do artigo 219 da Constituição Federal do Brasil de 1988 tratarão em maior ou menor medida sobre a disposição do texto citado.

Ainda, as questões sobre as omissões constitucionais presentes em determinada constituição não comporão objeto deste estudo, que está estritamente focado na análise do supracitado artigo.

1.3.2.4.1. Críticas quanto à liberdade, conformação do legislador e discricionariedade legislativa

A primeira das críticas aqui abordada trata especificamente sobre a limitação que recai sobre o texto constitucional de matriz dirigente. O núcleo do questionamento recai sobre a ideia de que a constituição dirigente seria não apenas um condutor às ações legiferantes do Estado, mas sim um limitador programático de transição de um modelo capitalista ao socialismo, para que um dia se fizesse à transição ao socialismo.

O principal autor desta crítica no Brasil é o professor Manoel Gonçalves Ferreira Filho. Seu ponto de partida é a Constituição Portuguesa de 1976, objeto de análise de Canotilho. Basicamente suas críticas visam rebater a ideia de que a própria Constituição Brasileira de 1988 seria um texto dirigente.

A crítica de Ferreira Filho parte do pressuposto de que o objeto de análise do formulador da tese sobre o dirigismo constitucional condicionara por completo a formulação da própria tese. Em outras palavras, uma vez que Gomes Canotilho se valera da Constituição 
lusitana que originalmente previa em seu artigo $2^{\circ}$ que o objetivo da República Portuguesa seria a transição para o socialismo, para o exercício democrático do poder pela classe trabalhadora. ${ }^{64}$

Desta feita, seria evidente que o texto constitucional dirigente é provido não apenas de normas programáticas que organiza as tarefas e fins do Estado. Para Ferreira Filho, toda a atividade estatal, a começar pela discricionariedade legiferante, teria um fim único: a transição para um estado de matriz socialista, que faria a posterior transição ao comunismo.

Sua crítica mais contundente foi publicada no artigo intitulado A nova Constituição brasileira: constituição-dirigente ou constituição-plano ${ }^{65}$. Em sua breve elaboração, posteriormente sustentada nas obras Estado de Direito e Constituição e Princípios fundamentais do Direito Constitucional, aponta o professor Manoel Gonçalves Ferreira Filho que, para Canotilho, o plano previsto no texto dirigente "se destina a operar a transformação para o socialismo, como etapa para a instauração, um dia, do comunismo"66.

O autor português cuidou de atacar o problema. Em seu artigo de $1996^{67}$, expôs que já em Peter Lerche a tese sobre a constituição dirigente se debruça não sobre uma lógica de transposição do plano metodológico-constitucional para o plano ideológico-constitucional. Conforme aponta:

\begin{abstract}
"Consequentemente, quando alguns autores equiparam a 'teoria da constituição dirigente' à ideologia social-comunista cristalizada numa constituição programática, estão a operar uma inaceitável transposição de planos. Da metodologia jurídico-constitucional saltam para a ideologia constitucional. Do esforço dogmático em torno da normatividade diferenciada dos vários tipos de normas e princípios retiram um propósito deliberado da revolução socialista através da constituição"68.
\end{abstract}

\footnotetext{
${ }^{64}$ Constituição da República Portuguesa, Artigo 2.o - (Estado democrático e transição para o socialismo) - A República Portuguesa é um Estado democrático, baseado na soberania popular, no respeito e na garantia dos direitos e liberdades fundamentais e no pluralismo de expressão e organização política democráticas, que tem por objectivo assegurar a transição para o socialismo mediante a criação de condições para o exercício democrático do poder pelas classes trabalhadoras.

${ }^{65}$ FERREIRA FILHO, Manoel Gonçalves. A nova Constituição Brasileira: constituição-dirigente ou constituição-plano. In Revista Convivium no 6, p. 502-504.

${ }^{66}$ Idem ibidem, p. 503.

${ }^{67}$ CANOTILHO, José Joaquim Gomes. Rever ou romper com a constituição dirigente: em defesa de um constitucionalismo moralmente reflexivo. Op. cit., p. 116.

${ }^{68}$ Idem ibidem, p. 117.
} 
Vê-se que para o autor há clara sobreposição do plano dogmático ao plano ideológico dos formuladores das críticas. Conforme já se apontou aqui, a tese da constituição dirigente é método de análise do texto constitucional e não um recorte ideológico da construção do texto analisado. Definir uma constituição como dirigente não significa fadá-la à transição ao socialismo.

Por tudo isso, em que pese a proposição estar historicamente bem situada - visto que a Revolução dos Cravos tinha eminente caráter socialista ${ }^{69}$ - não possui lastro dentro de uma análise mais detida dos escritos de Canotilho. Como foi analisada, a imposição material de fins e objetivos ao Estado nesses tipos de constituição não guarda relação necessária com determinada visão ideológica.

1.3.2.4.2. Críticas quanto às imposições constitucionais sobre as tarefas e fins do Estado previstos no texto constitucional

Em outra linha atuam aqueles que se opuseram à ideia de uma constituição dirigente por entenderem que, em suma, se as constituições fossem dotadas de um texto que orientasse materialmente a política prestada pelo Estado, em todas as suas faces, a tendência seria a estatização da vida social. Em outras palavras, o processo de dirigismo constitucional, caso a proposta dogmático-constitucional seja acatada, indicaria não apenas um engessamento da atuação do Estado. Seria também admitir que a constituição sob tal égide seja "um simples instrumento de estatização do mundo e da vida." 70

Porém, rebate Canotilho que assumir esta premissa seria desconsiderar o enquadramento lógico e histórico sob os quais as constituições daquele momento parecem estar inseridas.

\footnotetext{
${ }^{69}$ Conforme aponta Lincoln Secco, "ela [a revolução] obrigou todos a falar a sua linguagem: o socialismo. Os partidos políticos não tiveram tempo de adaptar a população ao seu discurso, como sói ocorrer nas democracias liberais baseadas em eleições rituais e regulares. Eles tiveram que ser ou fingir ser o eco das ruas". In SECCO, Lincoln. A Revolução dos Cravos e a crise do império colonial português. São Paulo: Alameda, 2004. pp. 120 e 121.

${ }^{70}$ CANOTILHO. José Joaquim Gomes. Rever ou romper com a constituição dirigente. Op. cit., p.117
} 
Citando Peter Häberle, aduz o jurista português que tal fato talvez seja o motivo pelo qual o jurista alemão "pudesse recentemente considerar a constitucionalização de normas-fins como uma característica do atual estágio de evolução das constituições estatais"71.

Isso não significa que a absorção do texto constitucional de dispositivos que contenham fins, objetivos ou tarefas para o Estado impliquem em uma monopolização estatal de tais tarefas. De fato, a preocupação categorial de Gomes Canotilho se esgota em dizer que são tarefas, fins ou objetivos que o Estado deve perseguir. Isso não impõe a ele (o Estado) limitações no sentido de atuar unicamente como gestor da atividade fim que levará a nação a cumprir o que fora desenhado em sua carta constitucional.

Por fim, lembra também o formulador da tese aqui estudada que sob esta crítica reside de fato um discurso que possui sérias feições ideológicas. Por vezes, dada a forma caricata com que se expõem as críticas à assunção de objetivos à organização estatal no texto constitucional, surgem dúvidas sobre a legitimidade de tais críticas, visto que induzem a ideia ideologicamente liberal de que seria necessário um Estado sem tarefas.

Uma vez feitas estas considerações, resta apenas a análise da principal e mais contundente crítica feita pelo próprio idealizador da tese aqui adotada: a morte da constituição dirigente, feita por José Joaquim Gomes Canotilho.

\subsubsection{A constituição dirigente morreu. Viva a constituição dirigente!}

É um dado da realidade que toda tese está sujeita a críticas. Em qualquer plano que se possa admitir, seja metódico, lógico ou mesmo formal, sabe-se que a criação de uma teoria - totalizante ou não - é passível de questionamentos em maior ou menor grau.

Porém, da mesma forma que a construção de uma teoria, no que tange à sua sustentação, enseja em riscos ao seu formulador, a mesma coisa valerá para as formulações feitas em oposição à tese estudada. Neste caso, cabe sempre lembrar que por vezes o conteúdo da crítica pode estar esvaziado por interesses que não acadêmicos. Por vezes, a crítica

${ }^{71}$ Idem ibidem, p. 118. 
proposta infelizmente reside por diferenças pessoais que nada tem a ver com o conteúdo teórico objeto do embate.

Não por menos, os posicionamentos contrários a uma teoria que mais costumam ecoar sejam aqueles propostos pelo próprio formulador da tese originária.

E é exatamente este o caso da declaração de morte da constituição dirigente.

Originalmente publicada em 1982, a obra aqui estudada passou apenas por uma reimpressão em 1994. Em 2001, publica-se nova edição, com um novo prefácio. Será assim neste novo prefácio que será insculpida a maior crítica que a tese poderia receber.

Ao final do prefácio da segunda edição, aponta Canotilho:

"Em jeito de conclusão, dir-se-ia que a Constituição dirigente está morta se o dirigismo constitucional for entendido como normativismo constitucional revolucionário capaz, de, só por si, operar transformações emancipatórias." 72

Os reflexos da inserção desta conclusão ao prefácio foram muitos e ressoaram por todos os estudiosos do direito constitucional luso-brasileiro. Dentre os que divergiam das proposições dirigentes, muitos se prontificaram a perpetrar que as colocações previstas se tornavam inócuas, fazendo com que aquelas construções feitas a partir da tese de Canotilho - como a de que a Constituição brasileira seria um texto eminentemente dirigente caíssem por terra. Do outro lado, pululavam dúvidas àqueles que adotavam e propunham em cima da teoria do jurista português. Vários acadêmicos brasileiros chegaram inclusive a realizar vídeo-conferência com o autor português, no ano de 2002, para elucidar o que fora proposto naquele fatídico prefácio.

De fato, especulou-se muito sobre o óbito da tão debatida tese. Hoje, se a teoria não frequenta o obituário teórico-constitucional, há de se considerar que o que fora brilhantemente exposto por Gomes Canotilho já não possui a mesma validade de outrora.

\footnotetext{
${ }^{72}$ CANOTILHO. José Joaquim Gomes. Constituição dirigente e vinculação do legislador: contributo para a compreensão das normas constitucionais programáticas. 2a Edição, Coimbra: Coimbra Editora, 2001, p. XXIX.
} 
Como fora exposto até aqui, o conteúdo dirigente de uma constituição se dá em um duplo plano. Primeiramente, trata-se de critério metodológico de classificação constitucional. Em um segundo momento, evoca-se dentro deste critério uma metódica hermenêutica que impõe aos gestores do Estado limites vinculativos ao exercício do poder discricionário, em especial sobre a discricionariedade legiferante do ente estatal vinculado àquela Constituição.

Como se observou, a obra em comento opera duas inferências. A primeira é o trabalho de conceituar as constituições ditas como dirigentes. A partir do escorço teórico de Peter Lerche, Canotilho avança para determinar que em sua concepção as constituições dirigentes são aquelas que possuem em seu corpo dispositivos programáticos (as chamadas normas-objetivo) que incumbem o Estado de transformar a realidade (daí a menção de que a constituição dirigente só tem sentido quando se considera a realidade como tarefa).

Por outro lado, a caracterização de um texto constitucional enquanto dirigente aduz a uma consequência lógica: a realização das previsões estampadas na referida constituição. É aí que se concentra boa parte do esforço teórico de Gomes Canotilho: demonstrar por via de um arcabouço teórico-constitucional extremamente refinado quais são as consequências vinculativas do que chamou de continuum de regulação operado em nível infraconstitucional para legitimar a referida constituição dirigente. É por isso, inclusive, que aponta o autor que o problema de tais constituições é antes de tudo referente à sua legitimação-legitimidade.

É possível vislumbrar que, mesmo sem toda a densidade exposta pelo autor, uma inferência é consequência lógica da outra. Melhor dizendo, ao configurar o que seria um texto constitucional dirigente, nasce a segunda questão, sobre como legitimar dentro da legislação infraconstitucional tal texto, garantindo sua execução.

É neste ponto que se fulcra o autor para afirmar que a constituição dirigente morreu. Aponta Canotilho que se nos valermos da ideia de que a constituição dirigente é um "normativismo constitucional revolucionário capaz, de, só por si, operar transformações emancipatórias", nos depararemos com uma teoria morta. 
Após tal colocação, Canotilho tratou de explicitar os motivos que o levaram a propor tais termos. Conforme indica o autor,

"Tomemos então a Constituição dirigente (portuguesa) como um projeto cristalizado, positivado, de uma revolução que se fez, que tinha de se fazer. Isso significa também que tinha os seus sujeitos históricos identificados no texto constitucional. Neste sentido, a Constituição dirigente é um projeto acabado de um projeto da modernidade, quer em termos de sujeito histórico, quer em termos de homem triunfante na sua capacidade de transformação (...). Quer queiramos quer não, quanto a essa Constituição dirigente temos de ser humildes e dizer que ela acabou." 73

Em suma, uma vez que os sujeitos históricos ${ }^{74}$ que articularam tanto a gênese daquela constituição quanto seriam, conforme o texto programático-dirigente, os agentes responsáveis em orientar os processos políticos não compõem mais os agentes sociais positivados no texto constitucional ${ }^{75}$, a Constituição dirigente estaria, sob tal aspecto, morta.

Isso não invalida, de plano, a tese sobre a conceituação de quais constituições seriam de fato, dirigentes. Ainda, lembra o jurista português que "penso que continuamos a ter algumas dimensões de programaticidade: o legislador não tem absoluta liberdade de conformação, antes tem de mover-se dentro do enquadramento constitucional"76.

Desta forma, vê-se então que a tão propagada morte da constituição dirigente está muito mais ligada a uma problematização política do que de uma metodologia constitucional. Como se observou, a proposição feita por Gomes Canotilho aponta para a transformação

\footnotetext{
${ }^{73}$ COUTINHO. Jacinto Nelson de Miranda (org.). Canotilho e a constituição dirigente. 2a edição, Rio de Janeiro: Renovar, 2005, p.14.

${ }^{74}$ Em outra passagem, cita Canotilho que a teoria da Constituição dirigente é se não uma teoria baseada na filosofia do sujeito. Quando questionado por Lênio Streck sobre o que seria o sujeito de sua teoria, o jurista português aponta que em sua teoria o sujeito "tem a ver sim com esquemas modernos do sujeito. $O$ sujeito transformador, o sujeito conquistador, tem mais a ver com esse espírito moderno do sujeito que domina a natureza, que assume esse projeto, esse processo, ou seja, o processo histórico, como um processo factível e configurável pelos próprios homens.". in COUTINHO, Jacinto Nelson de Miranda (org). Canotilho e a constituição dirigente. Op. Cit., p.26.

Em suma, ao apontar o termo sujeito histórico, indica Gomes Canotilho nos atores sociais que são responsáveis pela construção de uma nova ordem constitucional.

${ }^{75} \mathrm{Em}$ outra passagem o autor expressa a retirada do texto constitucional português a influência que setores participantes da Revolução dos Cravos, como os militares e a classe trabalhadora

${ }^{76}$ MIRANDA. Jacinto Nelson de Miranda (org). Op. Cit. p. 14.
} 
do sujeito histórico constitucionalmente positivado, que no fundo reflete a própria mudança da conjuntura política que envolveu a construção da Constituição em análise.

Entretanto, se levarmos em conta que, como apontou Gilberto Bercovici, a definição de Constituição só pode ser obtida a partir de sua inserção e função na realidade histórica, talvez não seja tão difícil apreender que a morte da Constituição dirigente é declarada no momento em que a política que lhe deu suporte estava completamente sufocada por outra, cujos sujeitos históricos são bem diversos dos anteriores.

Assim, talvez a morte da constituição dirigente possa ser, na verdade, a morte de sua legitimidade política.

\title{
1.3.3. A Constituição Federal de 1988 enquanto uma constituição dirigente.
}

Uma vez analisadas as diversas questões pertinentes à teoria da Constituição dirigente proposta por Canotilho, resta saber se a Constituição Federal de 1988 se enquadraria como tal.

Em verdade, sabemos que não são poucos os autores que indicam o conteúdo dirigente da atual carta constitucional brasileira. De início, cita-se José Afonso da Silva, que já no prefácio de sua obra aponta que:

\begin{abstract}
"A função garantia não só foi preservada como até ampliada na Constituição, não como mera garantia do existente ou como simples garantia das liberdades negativas ou liberdades-limites. Assumiu ela a característica de constituição-dirigente, enquanto define fins e programa de ação futura, menos no sentido socialista do que no de uma orientação social democrática, imperfeita, reconheça-se"
\end{abstract}

Seguindo esta linha, não são poucos os autores que concordam com José Afonso da Silva. Em uma exímia defesa da Constituição de 1988 como sendo instrumento dirigente, Eros Grau aponta que: "Ora, se tomarmos a Constituição dirigente como aquela oposta à Constituição estatutária ou orgânica, teremos que a atual Constituição Brasileira permanece dirigente" 78

\footnotetext{
${ }^{77}$ SILVA, José Afonso da. Curso de Direito Constitucional Positivo, 19ạ edição. São Paulo: Malheiros, 2001, p. 6.

${ }^{78}$ GRAU, Eros. A ordem econômica na Constituição de 1988, 12ª edição. São Paulo: Malheiros, 2007, p. 364.
} 
Este parece ser o mesmo entendimento de Gilberto Bercovici, citado na própria obra de Eros Grau e que ao longo desta dissertação fora repetidamente aludido. Conforme aduz, “[A] Constituição de 1988 é uma Constituição dirigente, pois define, por meio das chamadas normas constitucionais programáticas, fins e programas de ação futura no sentido de melhoria das condições sociais e econômicas da população"79.

A lista dos constitucionalistas brasileiros que mesmo indiretamente defendem a tese de que a Carta Constitucional de 1988 é um texto de matriz eminentemente dirigente é bastante extensa. Entretanto, resta demonstrar de fato quais seriam os dispositivos programáticos que incluiriam a constituição brasileira atualmente vigente dentro do rol das ditas constituições dirigentes.

Deparando-se com a constituição brasileira, é visível a quantidade de dispositivos programáticos contidos em seu texto. Logo ao início, no título I, dos princípios fundamentais, depara-se com o artigo $3^{\circ}$, que elenca os objetivos fundamentais da República Federativa do Brasil. Além de contar em seu caput o termo objetivos fundamentais, que já permite a inferência óbvia de se tratar de normas-objetivo, ou normas programáticas, a visualização de uma Constituição que enumera tarefas para o Estado brasileiro segue também nos incisos do artigo $3^{\circ}$. A construção de uma sociedade livre, justa e solidária, a garantia do desenvolvimento nacional, o objetivo de erradicar a pobreza e de reduzir as desigualdades sociais e regionais, bem como a promoção do bem comum sem preconceitos de origem, etnia, gênero ou afins são claras demonstrações das típicas normas-objetivo, enunciadas desde Lerche até Canotilho.

Ainda, é possível observar o conteúdo programático de diversos dispositivos, tais como o artigo 170, que traça como objetivo da ordem econômica brasileira "assegurar a todos a existência digna, conforme os ditames da justiça social”. No mesmo dispositivo é possível ainda observar outros objetivos a serem perseguidos pelo Estado brasileiro, como o pleno emprego e a defesa do meio ambiente, por exemplo.

\footnotetext{
${ }^{79}$ BERCOVICl, Gilberto. A problemática da constituição dirigente: algumas considerações sobre o caso brasileiro. Op. Cit., p. 36.
} 
No mais, o conteúdo programático também é muito visível no parágrafo único do artigo $4^{\circ}$, que informa o objetivo da República Federativa do Brasil em construir uma comunidade latino-americana de nações.

O que pode se observar da análise do texto constitucional brasileiro é que não apenas se trata de uma Constituição dirigente como sua matriz programática acena para um projeto nacional de desenvolvimento econômico-social com nuances claramente desenvolvimentistas.

De fato, há dentro da constituição econômica formal brasileira uma série de dispositivos que, se analisados em conjunto com o texto constitucional como um todo, permitem inferir que a maior tarefa que a Constituição de 1988 legou ao Estado brasileiro foi a superação do subdesenvolvimento sistêmico que o país parece carregar por toda a sua história. Assim, a direção que aponta o conjunto de normas-programa analisados dentro do escopo da chamada constituição econômica indica um projeto de Estado de bem estar social, propugnando que a redução das desigualdades sociais e regionais é, além de objetivo fundamental da República, um modelo de gestão do Estado.

Este é o que esta pesquisa procurará demonstrar a partir de agora. Fazendo um resgate histórico acerca das origens do debate sobre desenvolvimento econômico no Brasil, o próximo capítulo procurará apontar as causas que inspiraram a formulação de um determinado modelo de desenvolvimento ao Brasil.

Esta investigação, que começa com a pontuação histórica dos dois principais projetos de desenvolvimento do país, evoluirá para o nível constitucional, onde listando quais dispositivos deste projeto de desenvolvimento, surgirá a necessidade de que nos debrucemos sobre o artigo 219 da Constituição Federal, que trata sobre mercado interno.

Será com a utilização do arcabouço teórico criado por autores como Tercio Sampaio Ferraz Junior, José Afonso da Silva, Eros Grau, entre outros, que se criará o suporte analítico para o estudo do artigo em comento. 
Porém, antes tudo, caberá apontar como este artigo foi inserido em nossa constituição. É o que veremos a seguir. 


\section{CAPÍTULO 2. DESENVOLVIMENTO ECONÔMICO: A DISPUTA DE UM PROJETO NACIONAL}

\subsection{Introdução}

Após a sedimentação teórico-constitucional experimentada no primeiro capítulo, esta pesquisa segue tentando aprofundar conceitos, mas em outro rumo. Deixando momentaneamente as ciências jurídicas de lado, o capítulo que inicia buscará demonstrar as intensas discussões sobre os rumos da política econômica brasileira, focando objetivamente no debate sobre o modelo de desenvolvimento nacional a ser conduzido pelo Estado brasileiro.

Trata-se, assim, não apenas de um debate meramente centrado na produção da economia política brasileira. É, antes de qualquer outra coisa, um resgate histórico de como as forças que disputam o controle do aparato estatal se conformaram desde o segundo quarto do século XX.

Por ser um apanhado histórico, por mais que este tópico da dissertação aborde discussões sobre o desenvolvimento econômico brasileiro após a segunda metade do século passado, seria impossível dar um panorama minimamente preciso das discussões sobre os rumos do desenvolvimento econômico brasileiro sem que seja necessária uma ou outra incursão a um passado mais remoto da história do país.

Existem ainda outras ressalvas a serem feitas.

A primeira e talvez mais importante versa sobre qual o método utilizado para discutir os modelos de desenvolvimento econômico pensados e aplicados no país ao longo de todo o período selecionado. Além de um número suficientemente extenso de economistas e teóricos terem formulado proposições sobre o tema, o que inviabiliza o estudo detido de cada um deles, há também outro problema objetivo a ser enfrentado: como aglutinar as correntes teóricas próximas ao mesmo tempo em que se faz um recorte objetivo sobre as principais teses que debateram um projeto de desenvolvimento para o Brasil. 
Para solucionar esta questão, optamos por nos valer da sistematização proposta por Ricardo Bielchowsky em seu Pensamento econômico brasileiro: o ciclo ideológico do desenvolvimentismo. Em que pese sua abordagem se focar nos programas desenvolvimentistas entre a década de 1930 e 1964, a divisão proposta por Bielschowsky é suficiente para o que interessa nesta dissertação.

A segunda parte do problema levantado aqui diz respeito em quais linhas, escolas e autores esta pesquisa deveria se focar. Por questões práticas, o presente trabalho se debruçará sobre apenas três linhas propostas por Bielschowsky: o modelo neoliberal, o desenvolvimentismo de tipo nacionalista e o desenvolvimentismo de tipo não nacionalista. Apesar do autor ainda ter listado outros dois pensamentos, o socialista e os escritos de Ignácio Rangel, optou-se pela não inclusão de ambos neste capítulo.

As razões são essencialmente práticas: enquanto o pensamento socialista, organizado prioritariamente dentro do PCB, foi alijado do processo de discussão ativa e intervenção na política estatal pelas sucessivas cassações do registro partidário, o pensamento de Ignácio Rangel, apesar de profundo e complexo, não esteve no mainstream da discussão política e econômica de sua época.

A segunda ressalva a ser feita aqui é a evolução histórica do debate sobre o desenvolvimento econômico. Apesar de Bielschowsky ter optado por traçar uma evolução minimamente linear dos fatos, este capítulo, evitando tornar-se repetitivo e longo, tratará do avanço histórico das discussões ao longo dos tópicos aqui propostos.

Assim, ao mesmo tempo em que não nega as condicionantes históricas que permearam as formulações aqui abordadas, esta dissertação se preocupará primeiramente em apontar quais foram as principais linhas que forjaram a discussão sobre o desenvolvimento econômico brasileiro ao longo do século passado.

Por fim, resta ainda uma última nota.

Durante esta dissertação, o termo "desenvolvimento econômico" será exaustivamente repetido. Principalmente ao longo deste capítulo, serão muitas as referências ao processo 
de desenvolvimento econômico-social, que é parte integrante do texto presente ao artigo 219 da Constituição Federal. Ao nos debruçarmos sobre o conceito dentro das ciências econômicas, a primeira coisa que salta aos olhos não é a eventual polissemia do termo. Ao analisarmos a melhor literatura sobre o assunto, aparentemente não é impossível traçar um conceito amplo que abarque todas as escolas econômicas que discutiram ou discutem o tema. A maior dificuldade nasce da tentativa de não valorar o termo.

Em outras palavras, dado que o conceito de desenvolvimento econômico é antes de qualquer outra coisa político, torna-se impossível dissociá-lo de qualquer viés políticoideológico. Por mais que se tente buscar uma descrição neutra para o termo, ele sempre estará carregado de um viés. Por exemplo, se para um economista liberal o desenvolvimento econômico pode ser resumido à superação das desigualdades entre os indivíduos, para que compitam em pé de igualdade dentro da economia capitalista, um economista marxista utópico possivelmente considerará o desenvolvimento econômico a superação do capitalismo.

É por este motivo que este capítulo começa com a busca de um conceito de desenvolvimento que possa estar minimamente próximo das três correntes que serão aqui analisadas: a neoliberal, o desenvolvimentismo nacionalista e o "não nacionalista".

\subsection{Desenvolvimento econômico: em busca de um conceito}

Como dito anteriormente, definir a ideia de desenvolvimento econômico pode não ser tarefa tão simples. Como se verá, boa parte dos autores parece concordar com a tese central de um processo de evolução econômica, ou seja, de enriquecimento da população. Porém, de acordo com o momento histórico e o matiz político que guiou o formulador da definição, o conceito de desenvolvimento pode variar muito.

Neste tópico, tentaremos formular uma noção minimamente comum de desenvolvimento econômico. Para isso, serão apontados conceitos que, ao que parece, compõem boa parte do entendimento comum sobre o tema. Iniciando pela diferenciação entre desenvolvimento 
e crescimento, o plano deste tópico se encerra com a apresentação de alguns conceitos clássicos do termo.

\subsubsection{Desenvolvimento econômico e crescimento: variações de um mesmo sentido}

O estudo do conceito de desenvolvimento econômico é fundado em divergências. Uma das mais importantes talvez seja a utilização da palavra desenvolvimento em detrimento de outras, como por exemplo, crescimento. Há ainda aqueles que procuram diferenciar o desenvolvimento econômico do desenvolvimento: ao passo que um estaria restrito à economia, o outro estaria ligado ao pleno desenvolvimento humano, em todas as suas faces.

Celso Furtado trata de diferenciar desenvolvimento de crescimento. Para o autor,

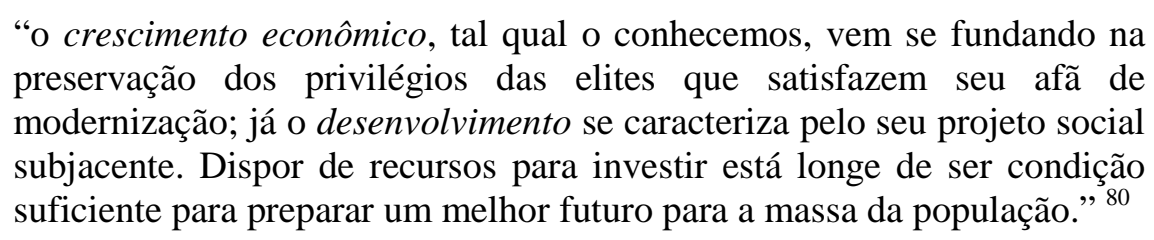

Em primeiro lugar, percebe-se que para o pai do desenvolvimentismo brasileiro, enquanto o crescimento é um processo de acumulação de capital com modernização técnica, o desenvolvimento se cunha por um projeto social atrelado a ele. Furtado faz a ressalva que, "quando o projeto social prioriza a efetiva melhoria das condições de vida dessa população, o crescimento se metamorfoseia em desenvolvimento." 81

Este entendimento possivelmente tem origem nos escritos de Schumpeter, que talvez tenha sido um dos primeiros economistas a identificar a necessidade de mudanças estruturais para a consecução do desenvolvimento econômico. ${ }^{82}$ Ao explicar seu conceito de "fluxo circular da vida econômica", Schumpeter indica que não será apenas pelo fluxo normal de circulação do capital na economia capitalista que se dará o desenvolvimento. É através de eventos extra-circulares que surgem as condições para o desenvolvimento econômico. ${ }^{83}$

\footnotetext{
${ }^{80}$ FURTADO, Celso. Os Desafios da Nova Geração. Revista de Economia Política 24(4): 483-486. Discurso na cerimônia de abertura da III Conferência Internacional Celso Furtado, Rio de Janeiro, URFJ, 2004, p. 484. ${ }^{81}$ Idem ibidem, p. 484.

82 PEREIRA, Luiz Carlos Bresser. Conceito Histórico de Desenvolvimento Econômico. Op. Cit., p. 4.

${ }^{83}$ SCHUMPETER, Joseph Alois. A Teoria do Desenvolvimento Econômico. São Paulo: Nova Cultural, 3a edição, 1988, pp. 43 a 54.
} 
Entretanto, esta diferenciação entre um conceito e outro parece não ser pacífica nem mesmo entre os estruturalistas. Raúl Prebisch, por exemplo, não constituiu o hábito de diferenciar os dois termos. Em textos como Crescimento, desequilíbrios e disparidades: interpretação do processo de desenvolvimento econômico e Problemas teóricos e práticos do crescimento econômico, Prebisch não diferencia um termo de outro. ${ }^{84}$

No mais, talvez seja Bresser-Pereira um dos economistas brasileiros que mais tenha despendido seu tempo em demonstrar que não há diferença necessária entre um conceito e outro. Para o autor, a ideia de desenvolvimento econômico implica no necessário crescimento, enquanto o crescimento, com raras exceções, deságua no desenvolvimento econômico.

Com a ressalva das economias dependentes do petróleo ou que padecem da doença holandesa, aponta Luiz Carlos Bresser-Pereira que,

"Em condições normais, o crescimento da renda per capita implica mudanças estruturais na economia e na sociedade. Distinguir crescimento de desenvolvimento econômico no plano histórico só faz sentido a partir de uma perspectiva teórica que supõe possível e frequente o aumento da renda per capita sem mudanças profundas na sociedade, quando isso só pode ocorrer em situações muito particulares. Nas situações normais, as mudanças tecnológicas e de divisão do trabalho que ocorrem com o aumento da produtividade são acompanhadas por mudanças no plano das instituições, da cultura, e das próprias estruturas básicas da sociedade." ${ }^{85}$

Vê-se, assim, que para o ex-ministro da Fazenda, a maioria absoluta dos casos de crescimento econômico sustentado implica, no longo prazo, em um cenário de desenvolvimento econômico. Para o autor, mesmo um processo de crescimento da renda salarial média que se estenda no tempo ensejará em desenvolvimento econômico.

De todo o caso, esta dissertação adotará o conceito furtadiano de desenvolvimento. Em que pese o indicativo de Bresser Pereira ser correto, há de se lembrar duas coisas: a primeira é

\footnotetext{
${ }^{84}$ PREBISCH. Raúl. Crescimento, Desequilíbrios e Disparidades: interpretação do processo de desenvolvimento econômico, passim. In: GURRIERI, Adolfo (org.). O Manifesto Latino-Americano e outros ensaios. Rio de Janeiro: Contraponto: Centro Internacional Celso Furtado, 2011.

${ }^{85}$ PEREIRA, Luiz Carlos Bresser. [online]. O Conceito Histórico de Desenvolvimento Econômico. Disponível em:

http://www.bresserpereira.org.br/papers/2008/08.18.ConceitoHist\%C3\%B3ricoDesenvolvimento.31.5.pdf , 2008, p. 4.
} 
que se a massa salarial tende a aumentar decerto haverá em alguma medida o desenvolvimento econômico. Primeiramente porque, por mais concentrada que seja a criação de salários (p.ex. nos setores médios), sempre existirá um ganho, ainda que marginal, para os setores subalternos. Ou seja, mesmo que o mote da atuação estatal não esteja focado na distribuição de renda, haverá sempre um ganho para todos os setores.

Em segundo lugar, imputar ao crescimento um desenvolvimento econômico natural é real na medida em que a cauda da curva histórica se estende no tempo. Exemplificando, é fato que o Brasil se desenvolveu economicamente ao crescer sua economia nos últimos cem anos. O incremento sustentado da renda de 1912 até hoje propiciou uma série de melhorias na condição de vida do brasileiro. Todos os índices que medem o grau de desenvolvimento do país, tais como expectativa de vida, escolaridade, renda média etc., cresceram muito. A questão é que, como já disse Keynes, no longo prazo estaremos todos mortos.

Ou seja: a questão premente a países como o Brasil está relacionada às mudanças estruturais dentro de nossa sociedade. Como se sabe, são pouquíssimos os momentos da história brasileira onde em um período factível - como, por exemplo, uma geração - se viu mudanças na estrutura sócio-econômica do país. Por tudo isso, ao menos no caso brasileiro, crescimento e desenvolvimento não necessariamente caminharam juntos.

\subsubsection{Desenvolvimento enquanto processo histórico.}

Talvez a primeira ideia que surja ao nos debruçarmos sobre o termo desenvolvimento econômico é fato óbvio de se tratar de um processo. No caso, um de processo histórico.

Para Luiz Carlos Bresser-Pereira, o processo de desenvolvimento "é um fenômeno histórico que passa a ocorrer nos países ou Estados-nação que realizaram sua Revolução Capitalista, já que só no capitalismo se pode falar em acumulação de capital, salários, e aumento sustentado da produtividade." ${ }^{86}$ Mais ainda, o economista brasileiro é enfático ao

${ }^{86}$ BRESSER-PEREIRA, Luiz Carlos. [online]. O Conceito Histórico de Desenvolvimento Econômico. Op. Cit., p. 1. 
afirmar que "o desenvolvimento econômico só pode ser compreendido a partir de uma perspectiva histórico-estrutural e keynesiana." 87

Como ele próprio aponta, a perspectiva histórico-estrutural se dá porque "nele (o desenvolvimento econômico) as três instâncias básicas da sociedade - a econômica e social, a cultural e a institucional - são interdependentes e mudam dialeticamente" ${ }^{88}$. Já a perspectiva keynesiana ocorre porque "nesse processo não basta analisar o desenvolvimento econômico pelo lado da oferta; é também essencial vê-lo pelo lado da demanda." 89

Por hora, basta apontar que a questão do desenvolvimento é, antes de qualquer outra coisa, um processo histórico. E o é não apenas sob o signo de um encadeamento de ações que se prolonga no tempo. Como Bresser Pereira enfatiza, a possibilidade do desenvolvimento econômico nasce com o capitalismo. Isto porque, para o autor, o desenvolvimento econômico só poderá ocorrer a partir do processo contínuo de acumulação do capital, aliado ao progresso técnico. ${ }^{90}$

Bresser-Pereira é acompanhado por Celso Furtado, que aponta ser o desenvolvimento "um fenômeno com nítida dimensão histórica." 91 Furtado completa ainda dizendo que à dimensão histórica, devem-se somar as características específicas de cada país em um dado momento histórico.

Mais ainda, Furtado indica que apesar de ser processo histórico, a situação de subdesenvolvimento de uma nação não é etapa necessária no processo de formação das economias capitalistas modernas. Como indica o autor, o subdesenvolvimento "é, em si,

${ }^{87}$ BRESSER-PEREIRA, Luiz Carlos. [online] Desenvolvimento Econômico e Revolução Capitalista. Disponível em:

http://www.bresserpereira.org.br/papers/2008/08.19.DesenvolvimentoERevolu\%C3\%A7aoCapitalista.20.6. pdf, 2008, p.1.

${ }^{88}$ Idem ibidem, p. 1.

${ }^{89}$ Idem ibidem, PP. 1 e 2. Convém lembrar que Keynes, pai da macroeconomia, foi o primeiro economista a relacionar a questão do pleno emprego à pauta do sucesso econômico de um país. Para Keynes, a manutenção de altos níveis de emprego é fundamental para a consecução do bem-estar de uma população. É neste sentido que Bresser Pereira se refere à demanda como política keynesiana de desenvolvimento: sem o emprego maciço das classes trabalhadoras, não há aumento na demanda.

90 Idem, p. 2.

${ }^{91}$ FURTADO, Celso. Desenvolvimento e Subdesenvolvimento. Rio de Janeiro: Contraponto: Centro Internacional Celso Furtado, 2009 p. 28. 
um processo particular da penetração das empresas capitalistas modernas em estruturas

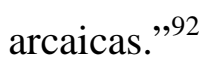

Ou seja: é um processo histórico de um determinado momento histórico - o capitalismo industrial internacionalista; cuja superação, via desenvolvimento, não é necessariamente um fato dado às economias subdesenvolvidas.

Ignacy Sachs também concorda com a afirmação do desenvolvimento como processo histórico. Segundo o economista,

"na medida em que o desenvolvimento é um processo - um desenvolver -
, só pode ser apreendido e compreendido na sua dimensão histórica, na
transição do passado, já ocorrido, para um futuro, em parte
predeterminado pelo passo, em parte aberto à invenção e à construção
pelos seus atores através da ação política." 93

Ao que parece, a dimensão processual-histórica do desenvolvimento parece ser ponto pacífico entre vários economistas que se debruçaram sobre a matéria. Quanto à questão da superação do subdesenvolvimento - via desenvolvimento econômico, há a pontuação de Furtado que, como se verá, foi extremamente influenciado por Raúl Prebisch.

Entretanto, por hora, existem outros pontos a abordar aqui sobre o conceito de desenvolvimento econômico.

\subsubsection{Desenvolvimento econômico e inovação.}

Outro ponto comum a muitas das teorias sobre desenvolvimento é a noção de inovação. De Joseph Schumpeter a Celso Furtado, há uma grande linhagem de economistas que atribui ao progresso técnico e seu consequente aumento de produtividade, a força motriz do desenvolvimento econômico.

\footnotetext{
${ }^{92}$ FURTADO, Celso. Desenvolvimento e subdesenvolvimento. 5a edição. Rio de Janeiro: Contraponto: Centro Internacional Celso Furtado, 2009, p. 171.

93 SACHS, Ignacy. Um Projeto para o Brasil: a construção do mercado nacional como motor do desenvolvimento. In, PEREIRA, Luiz Carlos Bresser; REGO, José Marcio. A Grande Esperança em Celso Furtado: ensaios em homenagem aos seus 80 anos. São Paulo: Ed. 34, 2001, p. 45
} 
Antes de apontar algumas das muitas inter-relações entre a inovação e o desenvolvimento econômico, há de se despender algumas linhas com a definição do termo inovação.

Possivelmente a definição mais conhecida nas ciências econômicas sobre a ideia de inovação seja de Schumpeter. O economista austro-húngaro ${ }^{94}$ é reconhecido, dentre outras coisas, por colocar no centro de sua teoria sobre o desenvolvimento econômico a inovação empresarial. Para o autor,

\begin{abstract}
"Produzir significa combinar materiais e forças que estão ao nosso alcance (cf. Capítulo I). Produzir outras coisas ou produzir as mesmas coisas com métodos diferentes, significa combinar diferentemente esses materiais e forças. Na medida em que as 'novas combinações' podem, com o tempo, originarem-se das antigas por ajuste contínuo mediante pequenas etapas, há certamente mudança, possivelmente há crescimento, mas não um fenômeno novo nem um desenvolvimento em nosso sentido. $\mathrm{Na}$ medida em que não for este o caso, e em que novas combinações aparecerem descontinuamente, então surge o fenômeno que caracteriza o desenvolvimento (...). O desenvolvimento, no sentido que lhe damos, é definido então pela realização de novas combinações." 95
\end{abstract}

As novas combinações a que o autor se refere tratam do processo de inovação tecnológica. O ponto aqui é definir o que seria a inovação. Para Schumpeter, inovação pode ser definida "as the setting up of a new production function. This covers the case of a new commodity, as well as those of a new form of organization such as a merger, of the opening up of new markets, and so on." 96

Outra referência à inovação feita por Schumpeter diz respeito ao custo financeiro. Para o economista, a inovação é peça fundamental, entre outras coisas, para a redução dos custos de operação da empresa.

Para Joseph Schumpeter, inovação também pode ser definida também:

"with reference to Money cost. Total cost to individual firms must, in the absence of innovation and with constant prices of factors, monotonically increase in function of their output. Whenever at any time a given quantity of output costs less to produce than the same or a smaller

\footnotetext{
${ }^{94}$ Schumpeter nasceu em Třešt', em 1883. À época, a cidade pertencia ao Império Austro-Húngaro e hoje é parte da República Checa.

${ }^{95}$ Idem ibidem, p. 48.

${ }^{96}$ SCHUMPETER, Joseph Alois. Business Cycles, vol I. New York: Bartelby's Books: Martino Publishing, 2005, p. 87.
} 
quantity did cost or would have cost before, we may be sure, if prices of factor have not fallen, that there has been innovation somewhere. ${ }^{, 97}$

Assim, para o economista a inovação tem um duplo caráter: ao mesmo tempo em que significa uma nova função produtiva, que pode dar-se pelo surgimento de uma nova commodity ou pela fusão de empresas ou ainda pela abertura de um novo mercado. A inovação significa também o ganho de produtividade por meio da redução do custo de produção.

Há ainda um último componente da inovação tecnológica, referente ao custo de produção. Conforme lembra Bresser-Pereira,

"O progresso técnico se manifesta sempre pelo aumento da produtividade do trabalho. Temos progresso técnico quando, no processo de acumulação de capital, novas técnicas são introduzidas que reduzem a quantidade de trabalho direto e indireto incorporado em um bem." 98

Uma vez definido o conceito de inovação aqui utilizado, resta saber apenas em que medida este conceito interage com a ideia de desenvolvimento econômico. Como se verá adiante, nem todas as correntes incorporaram a inovação ao processo de desenvolvimento. Entretanto, as correntes mais importantes dentro do espectro político-econômico brasileiro assim o fizeram, motivo pelo qual esta característica do desenvolvimento econômico está aqui incluída.

Ao apresentar as bases da corrente econômica estruturalista latino-americana, Octavio Rodríguez lembra que a inovação tecnológica, na atual conjuntura econômica internacional, se dá preferencialmente nas economias centrais. ${ }^{99}$ Este seria, para a teoria econômica estruturalista, um dos principais motivos do subemprego estrutural.

O processo de inovação tende a reduzir os custos de produção, aumentando os ganhos de capital. Dado que tais processos de inovação tendem, como dito, a ocorrer nas economias centrais, às economias periféricas restaria uma acumulação de capital que "será exígua na periferia, tendo em vista os baixos níveis de produtividade e renda médios que nela

\footnotetext{
${ }^{97}$ Idem ibidem, p. 88 e 89.

${ }^{98}$ BRESSER-PEREIRA. Luiz Carlos. [online]. Tendência Declinante da Taxa de Lucro. Disponível em: http://www.rep.org.br/pdf/24-2.pdf., p. 23.

${ }^{99}$ RODRÍGUEZ, Octavio. O estruturalismo latino-americano. Rio de Janeiro: Civilização Brasileira: CEPAL, 2009, p. 106 e 107.
} 
prevalecem" ${ }^{100} \mathrm{Ou}$ seja, o atraso tecnológico está, para os estruturalistas, no cerne da questão do subdesenvolvimento, traduzido aqui pelos altos (e persistentes) níveis de subemprego.

Veremos adiante que, para a escola estruturalista latino-americana, a qual o desenvolvimentismo de Celso Furtado está intimamente ligado, o modelo de desenvolvimento econômico depende do que Furtado chamou de "internalização dos centros de decisão econômica". Em breve síntese, consistiria no deslocamento do centro produtivo de bens de consumo para o mercado interno do país, gerando empregos, qualificando o setor industrial e criando um pátio industrial essencialmente nacional. ${ }^{101}$

Esta linha é fielmente seguida por Furtado, conforme aponta Eduardo da Motta e Albuquerque. Para o autor, as digressões de Celso Furtado começam sob a perspectiva histórica, listando os fatores que aprisionam economias subdesenvolvidas como o Brasil em seu processo de independência industrial. Albuquerque lembra que em Teoria $e$ Política do Desenvolvimento Econômico, Furtado aponta o aprisionamento tecnológico das economias periféricas em relação às centrais, articulando “"a orientação do progresso tecnológico' no centro e sua 'transposição' para outro contexto histórico, a periferia." 102

Mas as considerações furtadianas sobre a inovação tecnológica não se encerram por aí. Albuquerque lembra que será em Criatividade e dependência na civilização industrial, que Celso Furtado aprofundará a superação da dependência tecnológica como parte fundamental para a superação do subdesenvolvimento. Albuquerque aponta que para Furtado, "o controle da tecnologia é visto como fator chave, moldando a estrutura de poder internacional" e sendo aprofundada pela "proliferação de empresas transnacionais." 103

Citando propriamente o economista, Furado observa que

\footnotetext{
${ }^{100}$ Idem ibidem, p.109.

${ }^{101}$ Como dito, o tema será tratado a frente. Porém, para mais informações gerais sobre o tema: RODRÍGUEZ, Octavio. O estruturalismo latino-americano. Op. Cit., p. 82 a 84.

102 ALBUQUERQUE. Eduardo da Motta e. Celso Furtado, a polaridade modernização-marginalização e uma agenda para a construção dos sistemas de inovação e de bem-estar social. In: SABOIA, João; CARVALHO, Fernando J. Cardim de. Celso Furtado e o século XXI. Barueri: Manole; Rio de Janeiro: Instituto de Economia da Universidade Federal do Rio de Janeiro, 2007, p. 183.

${ }^{103}$ ALBUQUERQUE. Eduardo Mota. Op. Cit., p. 190.
} 
"Dos recursos de poder referidos, o primeiro - o controle da tecnologia constitui atualmente a trava mestra da estrutura de poder internacional. Reduzida às suas últimas consequências, a luta contra a dependência vem a ser um esforço para anular os efeitos do monopólio desse recurso detido pelos países centrais."

Entendida a dependência em Celso Furtado como sendo a relação de submissão econômica (e muitas vezes cultural) entre as economias subdesenvolvidas (ou periféricas) e as economias desenvolvidas (ditas como centrais), fica claro que na concepção de desenvolvimento de Celso Furtado, o progresso técnico é elemento-chave. Na verdade,a dependência, em última análise, é a dependência tecnológica que os países periféricos têm em relação às economias desenvolvidas.

Por fim, resta apenas lembrar que a concepção de desenvolvimento econômico ligado ao progresso técnico também reverbera em outros economistas estruturalistas. Além de Octavio Rodríguez, já citado aqui, economistas ligados à escola CEPALina, como Ennio Rodríguez e Osvaldo Sunkel, são claros a apresentar as concausas entre o subdesenvolvimento e a dependência tecnológica, dimensionando que sem um processo de constante inovação tecnológica - em muito a ser induzido pelo Estado - a superação do subdesenvolvimento se torna bastante prejudicada. ${ }^{105}$

Uma vez sedimentada o conceito de inovação e sua total interação com o processo de desenvolvimento econômico, passa-se agora a estudar alguns conceitos importantes de desenvolvimento econômico.

\footnotetext{
${ }^{104}$ FURTADO, Celso. Criatividade e dependência na civilização industrial. São Paulo: Companhia das Letras, 2008, p. 151.

${ }^{105}$ Para mais informações sobre o tema, vide: RODRÍGUEZ, Ennio. La endogeneización del cambio tecnológico: un desafio para el desarrollo. In: SUNKEL, Osvaldo. El desarrollo desde dentro: un enfoque neoestruturalista para la América Latina. Ciudad de Mexico: Fondo de Cultura Económica, 1995, p. 281 a 317.
} 


\subsection{Alguns conceitos clássicos de desenvolvimento econômico}

Como já dito anteriormente, o conceito apresentado pelo artigo 219 da Constituição Federal é o de desenvolvimento econômico. ${ }^{106}$ Também já fora dito que se trata de conceito amplo. Nos tópicos anteriores, procurou-se dar algumas pistas de elementos comuns de vários conceitos de desenvolvimento econômico: a diferenciação entre $\mathrm{o}$ termo desenvolvimento e crescimento; sua colocação enquanto processo histórico, e; sua íntima ligação com o processo de inovação.

Dada a extensão do tema, discutir elementos que conceituam as mais diversas ideias sobre desenvolvimento econômico, além de extenuante, passa longe de ser o objeto desta pesquisa. Por isso, até aqui, procuramos focar em alguns poucos elementos que não apenas constituem o imaginário do pensamento econômico sobre desenvolvimento como terão utilidade direta para o estudo do artigo 219 da Constituição, que é de fato o objeto de estudo desta dissertação.

Entretanto, há de se cuidar para que o generalismo não se torne vagueza de ideias. Assim, este tópico tem como função listar importantes contribuições das ciências econômicas sobre o conceito de desenvolvimento econômico.

Conforme fora apontado, a variação conceitual sobre desenvolvimento econômico está ligada aos entendimentos ideológicos sobre os processos histórico, social e econômico da humanidade. Assim, o alinhamento ideológico do teórico que formulou sobre o desenvolvimento econômico é determinante para seu entendimento sobre este processo. ${ }^{107}$

\footnotetext{
${ }^{106}$ Apenas como referência: Art. 219. O mercado interno integra o patrimônio nacional e será incentivado de modo a viabilizar o desenvolvimento cultural e sócio-econômico, o bem-estar da população e a autonomia tecnológica do País, nos termos de lei federal.

107 Sabe-se que este comentário é, antes de qualquer outra coisa, cercado de obviedades. Tanto nas ciências humanas quanto nas ciências sociais aplicadas, a matriz sócio-ideológica do autor influirá diretamente em suas pesquisas. Por mais que se queira implicar, especialmente às ciências sociais aplicadas, um véu de neutralidade presente em ramos científicos como a matemática pura ou algumas subdivisões da física, o fato é que não há como dissociar a construção teórica do Direito e da economia das matrizes e pressupostos ideológicos que os cercam. Aliás, a própria leitura de que toda leitura da realidade parte de uma determinada visão de mundo é ideológica, estando filiada à filosofia crítica. Como fonte para mais informações sobre o tema, sugere-se A ideologia alemã, de Karl Marx e Friederich Engels; História e consciência de classe de Georg Lukács, e; Ideologia: um mapa da questão, de Slavoj Žižek.
} 
Assim, o ponto principal aqui é listar algumas teses sobre o desenvolvimento econômico, para que ao final do Capítulo 4 seja possível deparar o artigo aqui analisado com tais conceitos, procurando encaixá-lo no que mais se adéqua ao entendimento proposto.

Outro fator a ser lembrado tem relação com as diferentes abordagens do tema desenvolvimento econômico. Desde conceitos forjados sob a ótica antropológica até os mais intimamente ligados a preceitos exclusivamente econômicos, é grande a variação conceitual de acordo com a aproximação do autor.

2.3.1. Desenvolvimento econômico: desenvolvendo conceitos

\subsubsection{François Perroux}

Trazemos aqui o ideário de François Perroux, economista francês de larga influência em países latinos, influenciou decisivamente o pensamento de inúmeros economistas, tais como Prebisch e Furtado.

Talvez por sua conceituação bastante aberta sobre o tema, seu pensamento não só serviu de base a inúmeros economistas latino-americanos, como também trouxe uma visão ampla sobre a questão do desenvolvimento, com algum viés antropológico.

É célebre a definição de desenvolvimento feita por François Perroux. O economista francês, criador da teoria dos pólos de crescimento, definiu a ideia de desenvolvimento como sendo "la combinaison des changements mentaux et sociaux d'une population qui la rendent apte a faire coître, cumulativement et durablement, son produit réel global." 108

A noção de alterações intelectuais, apontada pelo francês, parece ter um duplo sentido. $\mathrm{O}$ primeiro é a ligação direta do desenvolvimento com o progresso técnico. Este viés, estritamente econômico, tem a dimensão já citada, de que o desenvolvimento de um país implica necessariamente no progresso científico de seu setor produtivo.

\footnotetext{
${ }^{108}$ Em uma tradução livre: A combinação de mudanças intelectuais e sociais de uma população que as tornam adequada para crescer, cumulativamente e de forma permanente, seu produto real global. In PERROUX, François. L'Economie du XX siècle. Grenoble: Presses Universitaires de Grenoble, 2a edição, 1991, p. 191
} 
Ademais, como apontou Celso Furtado, está implicado ao processo de desenvolvimento um avanço cultural, sedimentando a produção histórico-cultural de um país, preservando-a e expandindo-a. ${ }^{109}$

Outro ponto importante da teoria de Perroux sobre o desenvolvimento é a ideia dos pólos de crescimento. Conforme aponta Bercovici, "a aparição de uma indústria nova ou crescimento de uma indústria existente difunde-se, o que faz com que, ao longo de grandes períodos, sejam espalhadas transformações que facilitam o surgimento de novas indústrias e a continuidade na difusão das inovações." 110

De forma sucinta, Perroux aduz que o desenvolvimento econômico se dá basicamente através de um modelo de pólos. O aparecimento - espontâneo ou não - de novas indústrias ou mesmo segmentos de uma economia nacional, produzem efeitos cumulativos ao processo de desenvolvimento.

Assim, para o economista francês, o processo de desenvolvimento de um país passa pela constante criação de novos centros de desenvolvimento que, cumulativamente, auxiliarão na marcha para a superação da situação subdesenvolvida em que se encontram.

\subsubsection{Albert Hirschman}

O modelo idealizado por Perroux guarda semelhança com outro economista que influenciou largamente os debates nacionais sobre a superação do subdesenvolvimento. Albert Hirschman, economista nascido na Alemanha, e que ganhou notoriedade por suas contribuições à economia política do desenvolvimento nos Estados Unidos da América, é o pai da tese do desenvolvimento desequilibrado.

Para Hirschman, mais importante do que uma definição para o desenvolvimento econômico, é sua metodologia de aplicação. Em que pese não apontar um conceito fechado de desenvolvimento, Hirschman indica que uma das principais causas para o

\footnotetext{
${ }^{109}$ FURTADO, Celso. Criatividade e dependência na civilização industrial. Op. Cit., passim.

${ }^{110}$ BERCOVICI, Gilberto. Constituição econômica e desenvolvimento. Op. cit., p. 46.
} 
desenvolvimento econômico seria não apenas a oferta de capital, mas também de empresários e administradores capacitados, além do investimento na força de trabalho e na inovação tecnológica. ${ }^{111}$

A primeira inferência é de que o economista alemão implica à atividade econômica privada a consecução do desenvolvimento. Entretanto, trata-se de meia-verdade. Albert Hirschman indica que o Estado tem papel de destaque na promoção do desenvolvimento. O autor, ao contrário de vários economistas liberais, aponta que o Estado pode cumprir não só uma função iniciadora, proporcionando o investimento inicial em um determinado segmento da economia, como propulsor indireto de outras. Vale-se do exemplo dos países que, para fomentar o nascimento de uma indústria siderúrgica, investem na criação de uma empresa estatal produtora de ferro-gusa, para permitir que a iniciativa privada possa desenvolver este setor daquele país. ${ }^{112}$

Hirschman, porém, não se esquece das ressalvas. É visível ao longo de sua obra que a atuação estatal deve ser sempre vista com ressalvas. Seu modelo pressupõe que o Estado deve se preocupar mais em ser influído do que influenciar o processo de desenvolvimento, dado que se não há dúvidas da sua importância no primeiro papel, pode fracassar no segundo. 113

Seja como for, a presença da ação estatal está imbuída em sua própria teoria sobre o desenvolvimento desequilibrado. Albert Oto Hirschman, conforme lembra Bercovici, indica que "a meta do desenvolvimento não seria eliminar os desequilíbrios, mas mantêlos, pois as tensões e desequilíbrios que induziriam o próprio desenvolvimento, por meio da sua contínua e incessante superação." ${ }^{114}$

Desta forma, para o economista alemão, o pressuposto do desenvolvimento é o desequilíbrio dos processos de criação de capital em um determinado país. Nas palavras do

\footnotetext{
${ }^{111}$ HIRSCHMAN, Albert. La estrategia del desarrollo econômico. Cuidad de México: Fondo de Cultura Económica, 1973, p.13.

${ }^{112}$ HIRSCHMAN, Albert. La estrategia del desarrollo econômico, cit., p.202 e 203.

113 Idem ibidem, p. 202.

${ }^{114}$ BERCOVICI, Gilberto. Constituição econômica e desenvolvimento. Op. Cit., p. 47.
} 
autor, "si se quiere que la economía siga creciendo, la tarea de la política de desarrollo es mantener las tensiones, desproporciones y desequilibrios."

Para Hirschman, a criação constante de desequilíbrios na economia de um país leva a criação de situações que busquem confortar aquele desequilíbrio prévio. Esta nova situação termina por gerar novos desequilíbrios, que buscarão se acomodar. É este o processo de desenvolvimento de Hirschman. Assim, tanto o Estado quanto a iniciativa privada teriam a missão de contribuir para que este processo se mantenha, acelerando o desenvolvimento daquele país.

\subsubsection{Walt Whitman Rostow}

Se Hirschman se notabilizou por sua contribuição ao desenvolvimento econômico desequilibrado, Walt Whitman Rostow marcou sua influência na teoria do desenvolvimento econômico por indicar uma linha bastante diversa ao crescimento desequilibrado.

Em sua principal obra sobre o tema, Etapas do desenvolvimento econômico, lista cinco etapas do desenvolvimento econômico da humanidade. Em um esquema aparentemente cartesiano, Rostow aponta para os estágios do desenvolvimento econômico e social da humanidade, mostrando como os países desenvolvidos chegaram a tal situação.

Apesar de aparentemente monolítica, a tese de Rostow é considerada uma grande contribuição à teoria do desenvolvimento econômico. Apesar de não fazer uma referência direta, os estágios do desenvolvimento aparecem de certa forma como os tipos puros weberianos, garantindo que em nenhum caso um povo ou nação esteja inteiramente naquele estágio de desenvolvimento.

W. W. Rostow, em seu auto-intitulado "manifesto não-comunista", aponta os cinco estágios do desenvolvimento: as sociedades tradicionais; as precondições para o take-off; o take-off propriamente dito;a marcha para a maturidade, e; a era do consumo em massa. ${ }^{116}$

${ }^{115}$ HIRSCHMAN, Albert. Op. Cit., p. 74. 
O autor inicia seu processo de entendimento sobre o desenvolvimento analisando os países em condições de subdesenvolvimento. Suas teses visam confrontar os modelos neoclássicos de desenvolvimento, uma vez que para ele, tais modelos seriam insuficientes para enfrentar a situação dos países subdesenvolvidos. Conforme aponta Rafael Gonçalves Guimeiro, “justifica o teórico que a teoria neoclássica foi formulada para atender as flutuações econômicas e resoluções de curto prazo nas economias desenvolvidas."

Para o economista, as economias tradicionais seriam aquelas que possuem uma organização social próxima do feudalismo, com uma economia agrícola de baixa produtividade. ${ }^{118}$ Esta seria, inclusive, a diferença dos países europeus às outras economias, dado que o fato de terem se libertado do feudalismo antes de outros países da Ásia ou da África conferiu ao europeus uma aceleração em direção à decolagem (ou takeoff).

O segundo estágio do caminho para o desenvolvimento seria a criação das condições da decolagem. Neste ponto, as sociedades estariam organizadas em torno de um Estado nacional. ${ }^{119}$ Alega ainda que este período de transição deve observar mudanças consistentes no plano econômico, com o alargamento do comércio e o surgimento da moderna empresa manufatureira. ${ }^{120}$

A terceira etapa para o desenvolvimento seria a decolagem. Apontada como o grande divisor de águas das sociedades modernas, a decolagem, ou take-off, seria "the interval when the old blocks and resistances to steady growth are finally overcome" ${ }^{\prime 21} \mathrm{~A}$ decolagem é, então, o período em que o crescimento se torna a regra, com ganhos maciços de poupança interna e investimentos, além do rápido crescimento industrial. Outro ponto

\footnotetext{
${ }^{116}$ ROSTOW, Walt Whitman. The stages of economic Growth, 3a edição. Cambridge: Cambridge University Press, 2004, PP. 4 a 11.

${ }^{117}$ GUIMEIRO, Rafael Gonçalves. Diálogo das teses do subdesenvolvimento de Rostow, Nurkse e Myrdal com a teoria do desenvolvimento de Celso Furtado, 2011, 144 f. Dissertação (Mestrado) - Universidade Federal de São Carlos, 03/03/2011, p. 48. Disponível em:

http://www.centrocelsofurtado.org.br/arquivos/image/201204271844510.Dissertacao\%20-

\%20Rafael\%20Gon\%C3\%A7alves\%20Guimiero.pdf

${ }^{118}$ ROSTOW, Walt Whitman. Op. Cit., p. 4.

${ }^{119}$ Idem ibidem, p. 6.

${ }^{120}$ Idem ibidem, p. 7.

${ }^{121}$ Idem ibidem, p. 7.
} 
central deste estágio é a absorção de novas técnicas, sendo que a inovação começa a ganhar papel de grande destaque nos processos econômicos. ${ }^{122}$

A marcha para a maturidade seria então o quarto período do desenvolvimento. Já com um crescimento constante e sustentado, as economias neste estágio estariam caminhando para setores de alta tecnologia, há a completa substituição de importações e o país se insere na economia internacional. Conforme aponta Rostow, a maturidade pode ser definida como:

"the stage in which an economy demonstrates the capacity to move beyond the original industries which powered its take-off and to absorb and to apply efficiently over a very wide range of its resources - if not the whole range - the most advanced fruits of (then) modern technology."123

O quinto e último estágio do desenvolvimento de Rostow consiste na entrada do país na era do consumo de massa. O autor aponta que as economias maduras do século $\mathrm{XX}$ acumularam um ganho real na renda per capta de tal monta que permitiu àquelas economias transcender o consumo de bens como alimentação, moradia e vestuário. Superando a necessidade primária de apenas consumir produtos de alta tecnologia, as sociedades que estão neste estágio tenderiam a investir tanto em seu bem-estar social quanto na previdência. $^{124}$

Vê-se assim que a ideia de desenvolvimento de Rostow, apesar de não ser absolutamente linear, comporta um alto grau de etapismo, ou seja, a adoção de uma ideia de etapas a serem superadas para que determinada sociedade alcance altos níveis de desenvolvimento.

Porém, a importância do conceito de Rostow talvez tenha sido a possibilidade de mapeamento das mais diversas economias mundiais. Suas diversas listagens de dados sobre economias subdesenvolvidas, o bloco ocidental e o bloco soviético, propiciaram o entendimento dos diversos processos de crescimento existentes à época.

Ainda, talvez sua maior contribuição tenha sido a noção de decolagem: para o economista, seu início se dá com um particular sharp stimulus, que será responsável por uma transição decisiva na história daquela sociedade. ${ }^{125}$ Mais do que isso, Rostow se preocupou em

\footnotetext{
${ }^{122}$ Idem ibidem, PP. 8 e 9.

${ }^{123}$ ROSTOW, Walt Whitman. Op. Cit., p.10.

${ }^{124}$ Idem ibidem, p. 11.

${ }^{125}$ Idem ibidem, p. 38 e 39.
} 
demonstrar o processo de países como Japão, Canadá e Suécia passaram por seus processos de decolagem, demonstrando como as altas taxas de investimento e de poupança permitiram a estes países um crescimento sustentado no tempo.

\subsubsection{Joseph Alois Schumpeter}

Dado que Schumpeter já fora citado anteriormente, cabe aqui apenas uma observação sobre sua teoria do desenvolvimento.

O economista austro-húngaro tem como lastro de sua teoria do desenvolvimento econômico a inovação empresarial. Schumpeter aponta que o processo de desenvolvimento de um país ocorre basicamente quando é rompido o ciclo básico da economia. Tal rompimento sempre se dá por via da inovação.

Schumpeter é, possivelmente, o primeiro economista a contribuir decisivamente para a discussão sobre desenvolvimento econômico. Sua influência talvez esteja presente em quase todos os economistas que pretenderam estudar o desenvolvimento econômico. François Perroux afirmou que "De Joseph Schumpeter, j'ai presque tout appris sur la dynamique de l'économie de marché." 126

Outra importante característica do pensamento schumpeteriano é seu constante alinhamento com o arcabouço marxista. Arnold Heerje, citando Paul Sweezy, indica que "Schumpeter is often mentioned in the same breath as Marx because they both believed that 'changes in methods of production are a basic feature of capitalism". 127

Independentemente das comparações entre Marx e Schumpeter, é fato que seu modelo de desenvolvimento econômico pressupõe que exista na economia a ser desenvolvida o progresso técnico. Como ele mesmo aponta, "O desenvolvimento, no sentido em que o

\footnotetext{
${ }^{126}$ PERROUX, François. La pensée économique de Joseph Schumpeter: les dynamiques du capitalisme. Paris: Librarie Droz, Genéve, 1965, prefácio.

${ }^{127}$ HEERJE, Arnold. Schumpeter on the economics of innovation and the development of capitalism.

Cheltenhan, UK; Northhampton, USA: Edward Elgar, 2006, p. 12.
} 
tomamos, é um fenômeno distinto, inteiramente estranho ao que pode ser observado no fluxo circular ou na tendência para o equilíbrio," 128

Schumpeter continuará seu discurso apontando que tais mudanças, espontâneas e descontínuas, ocorrem não na esfera dos consumidores de produtos finais e sim na esfera da vida industrial e comercial. ${ }^{129}$

Por isso, a figura do empresário inovador é essencial na teoria do referido autor. É através do empresário líder, que faz circular a inovação, que o fluxo circular da vida econômica é rompido, criando o desenvolvimento. Mais do que isso, para Schumpeter, a liderança econômica é item importante neste processo, dado que é resultado da viabilização econômica da inovação. ${ }^{130}$

O economista aponta também outros elementos fundamentais para o desenvolvimento, como o crédito e a poupança interna. Mas, para o que interessa nesta dissertação, a demonstração de que o cerne do processo de desenvolvimento do capitalismo nacional está na inovação no setor produtivo e comercial, por via do empresário, nos basta.

\subsubsection{Raúl Prebisch}

Prebisch pode ser considerado o maior economista da América do Sul e possivelmente da América Latina. $\mathrm{O}$ autor argentino foi o primeiro a evidenciar as vicissitudes da região latino-americana, mas não só. Foi ele que conduziu e instalou a Comissão Econômica para América Latina - a CEPAL.

A publicação de seu texto $O$ desenvolvimento econômico da América Latina e um de seus principais problemas, em 1949, é considerada o marco inicial para a formulação do que possivelmente foi a primeira escola econômica genuinamente regional: o estruturalismo latino-americano.

\footnotetext{
${ }^{128}$ SCHUMPETER, Joseph. A. A teoria do desenvolvimento econômico. Op. Cit., p. 47.

${ }^{129}$ Idem ibidem, p.48.

${ }^{130}$ Idem ibidem, p. 61 e 62.
} 
Pode-se dizer que a obra de Prebisch influenciou, em alguma medida, a todos os economistas da região. Inclusive os brasileiros. Sua abordagem original, que imputa à geopolítica econômica mundial inúmeras situações que constituem o estado de subdesenvolvimento dos países da América Latina, criou condições para que uma cepa enorme de teóricos florescesse na região.

Do estruturalismo à teoria da dependência, em alguma medida todos os trabalhos tocam nas proposições de Prebisch.

A primeira grande contribuição do economista argentino diz respeito à introdução do conceito centro-periferia nas relações econômicas internacionais. ${ }^{131}$

Partindo da noção de que a absorção do progresso técnico na produção econômica é disforme entre os países desenvolvidos e os subdesenvolvidos, Prebisch aponta para a configuração de dois grandes pólos no cenário econômico mundial: os países centrais, importadores de matéria-prima e exportadores de produtos manufaturados; e os países periféricos, exportadores de commodities e importadores de bens manufaturados. ${ }^{132}$

Mais do que simplesmente uma situação temporária, o subdesenvolvimento dos países periféricos é uma condição específica. Para Prebisch, trata-se não de um atraso, mas de um modo de ser de algumas economias, que trabalham em subserviência a outras.

Como lembra Rodríguez,

“essa concepção apresenta uma acentuada diferença em relação às teorias correntes do crescimento a longo prazo, pois não procura captar o processo de acumulação e avanço técnico em uma economia capitalista modelo, considerada isoladamente, mas elucidar que características assume tal processo ao serem propagadas as técnicas capitalistas de produção no âmbito de um sistema econômico mundial composto por centro e periferia." 133

${ }^{131}$ Conforme RODRÍGUEZ, Octavio. O estruturalismo latino-americano. Op. Cit., p. 79.

${ }^{132}$ PREBISCH, Raúl. O desenvolvimento econômico da América Latina e seus principais problemas. In: BIELSCHOWSKY, Ricardo (org.). Cinquenta anos de pensamento na CEPAL. Rio de Janeiro: Record: CEPAL, 2000, PP. 69 a 134.

${ }^{133}$ RODRÍGUEZ, Octavio. Op. Cit., p. 80. 
Entretanto, a tese de Prebisch irá transcender a crítica geopolítica. Mais do que isso, o autor argentino se focará na crítica ao pensamento vigente até então sobre os termos de troca.

Raúl Prebisch, em conjunto com outros economistas, se focará na crítica ao proposto por David Ricardo sobre as compensações econômicas no mercado internacional. Até então, admitia-se que o simples fato de um país ser exportador de commodities não poderia ser considerado necessariamente um problema. Em outras palavras, o fato dos países exportadores de produtos industrializados conseguirem, através da inovação tecnológica, introduzir bens de consumo mais caros e forçarem os países exportadores de matériasprimas a exportarem mais commodities para compensar tal aumento de preços poderia ser equilibrada através dos ganhos de produtividade na extração ou produção de matériasprimas.

Assim, dentro do cenário econômico internacional, bastaria a introdução de uma nova tecnologia no setor agrícola brasileiro, por exemplo, para que se compensasse - via aumento da produtividade - a introdução de bens manufaturados ou mesmo bens de capital no mercado, pelas economias centrais.

A crítica a este modelo estático foi denominada como "deterioração dos termos de troca", que como bem define Bielschowsky, surge:

“como contestação ao princípio ricardiano, de acordo com o qual a distribuição física desigual das técnicas modernas é compensada através das transferências dos ganhos de maior produtividade por meio de preços menores - via mercado - desde que prevaleça a concorrência perfeita"134.

Este é, sem dúvida, um dos eixos do pensamento prebischiano sobre a situação dos países latino-americanos. Tal condição geopolítica arrasta os países subdesenvolvidos para uma situação de crescimento permanentemente desigual. Caso nada seja feito para romper com este cenário, ele se perdurará ad infinitum. ${ }^{135}$

\footnotetext{
134 BIELSCHOWSKY, Ricardo. Pensamento econômico brasileiro. Op. cit., p.16. É interessante também observar que a deterioração dos termos de troca se torna cada vez mais intensa neste exato momento, uma vez que os preços das commodities se encontram em queda livre.

${ }^{135}$ Para um quadro esquemático do modelo de perpetuação das relações centro-periferia, vide.: RODRÍGUEZ, Octavio. O estruturalismo Latino-Americano. Op. Cit., p. 85.
} 
A solução apontada por Prebisch, que será formulada por inúmeros economistas estruturalistas, seria a transformação do modelo de desenvolvimento, saindo do cenário de um desenvolvimiento hacia afuera para um desenvolvimiento hacia adentro.

O desenvolvimento para fora dos países periféricos, como aponta Rodríguez, possui dois fatores importantes em relação às suas estruturas produtivas. A primeira é o alto grau de especialização dessas economias, "já que uma parte substancial dos recursos produtivos é destinada a sucessivas ampliações do setor exportador de produtos primários." ${ }^{136}$ Ainda, lembra Rodríguez que neste cenário, a demanda de bens e serviços, que aumenta e se diversifica, se satisfaz em grande parte por meio de importações.

No lado oposto da situação dos países periféricos estão os países centrais. Com um setor industrial diversificado e homogêneo, tais nações atuam como verdadeiros centros fabris em escala planetária. ${ }^{137}$

A solução, proposta inicialmente por Prebisch e largamente desenvolvida pela escola estruturalista será então a reconfiguração do modelo de desenvolvimento dos países periféricos. Saindo de um quadro geral de uma economia debilitada e altamente especializada em uma pequena cesta de commodities destinada à exportação, os países da periferia devem se focar no que se convencionou chamar de desenvolvimento para dentro.

Através de um processo contínuo de substituição de importações, tais nações deveriam buscar a independência econômica em relação aos países centrais. A fórmula: industrialização ampla e contínua, transformando o pátio industrial nacional, aos moldes dos países centrais, em algo diversificado e homogêneo. ${ }^{138}$

Basicamente, a ideia do economista argentino está focada em criar um amplo mercado interno aos países periféricos, que pudesse absorver os ganhos com a venda de

\footnotetext{
${ }^{136}$ Idem ibidem, p. 81

137 PREBISCH, Raúl. O Desenvolvimento econômico da América Latina e seus principais problemas. Op.cit., p.72.

${ }^{138}$ Basicamente, a homogeneidade a que se refere Prebisch diz respeito à absorção da inovação tecnológica de forma equânime pelos diversos ramos industriais do país. Já a diversificação se refere a um setor produtivo com vários segmentos.
} 
commodities e promovesse um círculo virtuoso de crescimento econômico, superando a situação de subdesenvolvimento.

Ao longo de sua vida, Prebisch fez mais do que simplesmente criar uma agenda industrializante para os países periféricos. Seus escritos abordaram desde as limitações monetárias dos países periféricos, que por sua situação de exportadores de commodities bens que tradicionalmente possuem uma baixa elasticidade - têm grandes dificuldades de criar uma poupança interna para sustentar as inversões necessárias ${ }^{139}$; até a criação de um mercado comum latino-americano. ${ }^{140}$

Vê-se assim que Prebisch teve uma vida destinada a pensar a superação do subdesenvolvimento econômico dos chamados países periféricos. Suas contribuições foram decisivas não apenas para a criação do estruturalismo latino-americano ou da própria CEPAL, organização da qual foi presidente por treze anos. Seu legado é sem sombra de dúvida responsável pela escola nacional desenvolvimentista brasileira, liderada por Celso Furtado.

Assim, uma vez colocada esta breve análise sobre algumas importantes teorias sobre o desenvolvimento econômico, este trabalho busca agora entender como o debate sobre o desenvolvimento se deu dentro do Brasil. Nos valendo do proposto por Bielschowsky, a ideia será demonstrar três das principais linhas de pensamento sobre o desenvolvimento nacional.

2.4. Transposição do conceito de desenvolvimento econômico à realidade brasileira: a construção teórica nacional

\footnotetext{
${ }^{139}$ PREBISCH, Raúl. Os principais problemas da técnica preliminar de programação. In: GURRIERI, Adolfo (org.). O manifesto Latino-Americano e outros ensaios. Op. Cit., p. 299 a 317. Vide especialmente p. 304 e 305.

${ }^{140}$ PREBISCH, Raúl. O mercado comum latino-americano In: GURRIERI, Adolfo (org.). O manifesto LatinoAmericano e outros ensaios. Op. Cit., p. 343 a 391.
} 
Como lembra Bielchowsky, o Brasil parece ter, ao menos por boa parte de sua história, uma tradição econômica liberal. ${ }^{141}$ Entre o século XIX e a década de 1930, os escritos sobre economia publicados no país parecem ter grandes inflexões para o campo liberal.

Desde então, setores do espectro político brasileiro iniciam, ainda que aos poucos, o debate sobre o desenvolvimento econômico. Como lembra Skidmore, se referindo ao período iniciado em 1930, "nenhum estudo da moderna política brasileira pode se dar ao luxo de ignorar a maneira pela qual as pressões econômicas restringiram as opções das chamadas elites." ${ }^{142}$ Isso porque, como aduz o próprio autor, desde 1930 e especialmente a partir da década de 1950, se fazia presente a extrema necessidade de fazer "dolorosas escolhas em política econômica."

O fato é que será a partir do surgimento do Estado Novo, com Getúlio Vargas, que o efetivo debate sobre a construção de um projeto nacional tomará corpo. Tal projeto não poderia caminhar senão com a criação de um sólido projeto de desenvolvimento nacional, o que não ocorreria sem sérias controversas.

O projeto de Vargas, que ao mesmo tempo em que flertou com o fascismo procurou fugir do personalismo tradicional daqueles regimes, causou perplexidade não só ao povo brasileiro. Karl Lowenstein, famoso jurista alemão, descreve em seu "Brazil Under Vargas", fatos curiosos como a criação de um non-party state. ${ }^{144}$ No campo econômico, Lowenstein indica que Vargas seguiu a tendência latino-americana de libertar a nação da influência econômica estrangeira. ${ }^{145}$

Desde então, não foram poucos os economistas e pensadores brasileiros que se debruçaram sobre a questão do desenvolvimento (ou sua falta). Ao longo de quase cem anos, a academia e a política nacional introduziram como pauta permanente a superação do estágio de subdesenvolvimento econômico. Até hoje, apesar do sucessivo avanço na redução das

\footnotetext{
${ }^{141}$ BIELSCHOWSKY, Ricardo. Pensamento econômico brasileiro: o ciclo ideológico do desenvolvimentismo. $2^{a}$ edição. Rio de Janeiro: Contraponto, 2000, p. 38.

142 SKIDMORE, Thomas E. Brasil: de Getúlio Vargas a Castelo Branco (1930-1964). 7a edição. Rio de Janeiro: Paz e Terra, 1982, p.20.

${ }^{143}$ Idem ibidem, p. 19.

${ }^{144}$ LOWENSTEIN, Karl. Brazil under Vargas. Nova lorque: The Macmillan Company, 1942, p. 141 a 154.

${ }^{145}$ Idem ibidem, p. 205.
} 
desigualdades sociais, o Brasil segue entre os vinte países mais desiguais do mundo, ao mesmo tempo em que é a oitava maior economia do planeta.

Retomando a questão do debate sobre o desenvolvimento, a cepa de economistas que debateram o crescimento econômico e social do país é grande. Entretanto, se a discussão ficou corrente desde o fim da República Velha, em poucos momentos ela foi tão profícua quanto nas décadas de 1950 até 1990. Durante quase quarenta anos, a produção intelectual sobre o tema foi, como aponta Bielschowsky, grande. Já a disputa sobre a implantação de um projeto de desenvolvimento, não.

Como se verá adiante, o golpe militar de 1964 e o sucessivo endurecimento da censura e das políticas do regime fará cessar por completo o debate sobre qual projeto de desenvolvimento o Brasil deveria adotar. Tanto foi assim que o Ato Institucional $\mathrm{n}^{\circ} 1$, em 9 de Abril de 1964, já listava Celso Furtado dentre os brasileiros que tiveram seus direitos políticos cassados.

As discussões sobre os rumos do desenvolvimento econômico brasileiro foram retomados com o fim do período de exceção. A constituinte que formulou nossa atual Constituição parece ter sido, desde o fim da ditadura, a maior arena de enfrentamentos sobre o tema. Menos pelas comissões e mais pela presença do tema no seio da sociedade, questões sobre a atuação do Estado na economia emergiram novamente.

É fato também que a prevalência do assunto, ao menos dentro das esferas governamentais, durou pouco. Já no mandato de Fernando Collor de Mello se instituem medidas que, na contramão da Carta Constitucional, tomaram rumo bem distinto do formulado dentro do campo desenvolvimentista. O sepultamento do debate parece ter acontecido com Fernando Henrique Cardoso, que em seu discurso de despedida do Senado, em 14 de dezembro de 1994, apontaria como meta de seu governo colocar fim à era Vargas.

Ainda assim, desde 1930 o país produziu um sem-número de teorias e formulações sobre formas de superação do estágio de subdesenvolvimento em que o nos encontramos. É o que se passará a estudar a partir de agora. 
2.4.1. Projetos para o desenvolvimento econômico nacional

Conforme dito anteriormente, o modelo adotado nesta dissertação será o previsto por Ricardo Bielschowsky em seu Pensamento econômico brasileiro. Dividindo as correntes da economia brasileira entre neoliberais, desenvolvimentistas nacionalistas e nãonacionalistas, socialistas e o pensamento de Ignácio Rangel, Bielschowsky tratou de dar aos diversos matizes ideológicos brasileiros uma divisão factível.

Optamos por não aprofundar nem o pensamento dito como socialista nem os modelos de Ignácio Rangel. A discussão sobre o modelo de desenvolvimento do país esteve nas mãos, basicamente, do desenvolvimentismo nacionalista liderado por Celso Furtado e o modelo não-nacionalista, cuja figura central foi Roberto Campos.

O neoliberalismo, protagonizado por Eugênio Gudin e Octávio Bulhões será referenciado aqui por dois motivos: o primeiro é a longa tradição liberal-econômica brasileira. $\mathrm{O}$ segundo é que, com o fim da ditadura, sob a onda neoliberal que assolou o mundo, foi o modelo que, se não estava previsto dentro do texto constitucional de 1988, de fato implementado no país.

\subsubsection{A proposta neoliberal}

As propostas neoliberais sobre o modelo econômico nacional, como bem se referiu Bielschowsky, se reduziram basicamente à defesa da economia de mercado. Liderados por Daniel de Carvalho, Denio Nogueira, Alexandre Kafka e principalmente Octávio Gouveia Bulhões e Eugênio Gudin, os neoliberais se notabilizaram no Brasil, ao menos no início da década de 1930, em alguma permissividade à intromissão do Estado na economia privada. ${ }^{146}$

Se em um primeiro momento o pensamento neoliberal brasileiro admitia alguma forma de intromissão estatal nos processos econômicos, esta certamente não dizia respeito ao planejamento estatal para a promoção da industrialização nacional.

\footnotetext{
${ }^{146}$ BIELSCHOWSKY, Ricardo. Pensamento econômico brasileiro, cit. p. 38.
} 
Liderados por Eugênio Gudin, engenheiro de formação e patrono das ciências econômicas brasileiras, os neoliberais se opuseram - como ainda se opõem -a qualquer programa estatal de fomento à industrialização.

Mais do que isso, Gudin refutava que a condição de nação subdesenvolvida de países como o Brasil e a Argentina estivesse sob a égide de uma questão política internacional.Em seu O caso das nações subdesenvolvidas, Gudin aponta que

"Se a civilização ocidental se desenvolveu invariavelmente fora da zona tropical, se o clima constituiu sempre um fator capital do metabolismo orgânico do homem, com repercussão direta no desenvolvimento econômico, se a grande agricultura é sinônima de planície, se o obstáculo das cordilheiras erigidas pela natureza sempre dificultou a conquista da terra pelo homem enquanto que os rios facilmente navegáveis a facilitaram, se os países que dispuseram de carvão de boa qualidade e de petróleo fácil encontraram nesses elementos físicos precioso elemento de prosperidade,não há como negar que o desenvolvimento econômico é primordialmente função do clima, dos recursos da Natureza e do relevo do solo." $" 147$

O patente determinismo, que permeou praticamente toda a obra do autor sobre a questão do subdesenvolvimento, mostra a franca oposição a um modelo desenvolvimentista, seja ele qual for. Ao passo que Gudin tornava clara sua visão geográfico-determinista sobre o desenvolvimento das nações, os desenvolvimentistas partiam do pressuposto da atuação do homem sobre o meio, com o fim de alterar uma estrutura pré-estabelecida.

Este posicionamento, abertamente anti-estatal, não se resumia ao campo do desenvolvimento. Como lembra Maria Angélica Borges, Gudin cunhara o seu próprio conceito de capitalismo naturalista. Para o autor, o modelo natural do desenvolvimento do capitalismo seria o inglês.

Tal feita reservaria não só à Inglaterra, mas ao resto do mundo, o modelo a se seguir: ao contrário do senso comum, qual seja, da perseguição do desenvolvimento econômico nos moldes ingleses, Gudin apregoava o contrário. Para ele, a ordem natural do capitalismo pressupunha uma espécie de ordem heliocêntrica, onde o sol seria a Inglaterra e os demais

\footnotetext{
${ }^{147}$ GUDIN, Eugênio. O caso das nações subdesenvolvidas. Revista Brasileira de Economia. Rio de Janeiro vol VI, no 3, p. 50 .
} 
países, seus planetas e satélites. Nas palavras de Maria Borges, para Gudin, o mundo do equilíbrio perfeito "é aquele onde realizávamos a nossa vocação agrária". 148

Como lembra Bresser-Pereira, a defesa intransigente de um Brasil agro-exportador servia de enfrentamento às teses de Prebisch, já apresentadas aqui. ${ }^{149150}$ Para Gudin, Bulhões e os adeptos do neoliberalismo, o foco do poder estatal seria na manutenção de um câmbio favorável às exportações.

$\mathrm{Na}$ verdade, toda a política econômica neoliberal, como em qualquer outro lugar do mundo, primava única e exclusivamente pela intervenção estatal nas questões monetárias.

É o que descreve Bielschowsky, ao apontar que a orientação fundamental de Gudin sobre o déficit externo, para ele a principal causa da persistente inflação brasileira, seria a estabilidade monetária. ${ }^{151}$

A questão é que para o pensamento neoliberal brasileiro em geral e para Gudin em particular, concordar com a estabilidade não pressupunha discordar, de imediato, da proposição estruturalista da deterioração dos termos de troca.

Ao contrário, como lembra Bielschowsky, Gudin aprovava a tese da contínua marcha decrescente dos preços dos insumos brasileiros no mercado externo. Entretanto, o autor assinalava que, em primeiro lugar, parte desta deterioração advinha do constante processo inflacionário que assolava os países da região. ${ }^{152} \mathrm{Em}$ outra monta, a solução seria a correção cambial, hipótese conjugada que auxiliaria no combate à inflação.

Outro ponto a ser observado entre os neoliberais, até pelo seu caráter liberalinternacionalista, era o excesso de ressalvas ao nacionalismo econômico. Apesar de cânones do desenvolvimentismo não-nacionalista, como Roberto Campos, iniciarem suas

\footnotetext{
${ }^{148}$ BORGES, Maria Angélica. Eugênio Gudin: as controvérsias do capitalismo caboclo. Revista de Economia Política, vol. 20, no 4 (80), outubro-dezembro de 2000, p. 105.

${ }^{149}$ BRESSER-PEREIRA, Luiz Carlos. Interpretações sobre o Brasil. In Maria Rita Loureiro, org. (1997) 50 anos de Ciência Econômica no Brasil. Rio de Janeiro: Editora Vozes, 1997, p. 17 a 69.

${ }^{150}$ Também presente em BIELSCHOWSKY, Ricardo. Pensamento econômico brasileiro, cit., p. 41.

${ }^{151}$ BIELSCHOWSKY, Ricardo. Pensamento econômico brasileiro, op. Cit., p. 68.

152 Idem ibidem, p. 48.
} 
carreiras como pupilos de economistas como Gudin e Bulhões, o elemento que os manteve distante, ao menos em toda a sua produção acadêmica, foi a questão nacionalista.

Octávio Bulhões, por exemplo, emitia muitas ressalvas sobre o nacionalismo político econômico, chegando a apontar que as questões da nacionalização do petróleo e da posição contrária à remessa de lucros das empresas multinacionais ao exterior seriam subversões do pensamento nacionalista. Para Bulhões, o nacionalismo exacerbado transformaria os meios - a busca pela capitalização da economia nacional - em fins, causando o soterramento da busca pelo bem-estar, fim último dos processos econômicos. ${ }^{153}$

Este era, em linhas gerais, o pensamento neoliberal brasileiro. Qualquer outra forma mais severa de intervenção do Estado na economia seria absolutamente repelida. Quando confrontado com as teses estruturalistas, a repulsa à presença do Estado no planejamento e nas reformas econômicas era patente.

A aversão neoliberal ao planejamento é consequência natural de uma intransigente defesa da economia de mercado como única via para o sucesso econômico brasileiro. Transpondo seu pensamento como sendo, em alguma medida, o pensamento único, Gudin chega a afirmar que "planejar o combate à inflação é o único planejamento por que anseia o País.",154

A questão da liberdade de mercado ou - do capitalismo natural - não se limitaria à aversão ao planejamento estatal.

Ao citar as reformas de base, promovidas no bojo do Plano Trienal de João Goulart, Gudin era enfático ao afirmar que "é preciso ser integralmente (não parcialmente) imbecil para acreditar que essas reformas, quase todas desaconselháveis, aliás, possam ter qualquer influência sobre o progresso econômico e social do País."155

\footnotetext{
153 BULHÕES, Octávio Gouvêa de. Economia e nacionalismo. Revista Brasileira de Economia. Vol. 6, no 1, 1952, p. 102 a 109.

${ }^{154}$ GUDIN, Eugênio. Análise de problemas brasileiros. Rio de Janeiro: Agir, 1965, p. 437.

${ }^{155}$ Idem ibidem, p. 128.
} 
Talvez, a melhor análise sobre o pensamento neoliberal, para o que aqui interessa, seja mesmo de Ricardo Bielschowsky.

Como aponta o autor, o pensamento neoliberal não descarta o desenvolvimento econômico. Apesar do fatalismo geopolítico, descrito aqui na citação de Gudin, o pensamento econômico neoliberal, assim como qualquer outra corrente econômica, entende o desenvolvimento econômico, antes de qualquer outra coisa, como um processo contínuo de elevação de produtividade. ${ }^{156}$ A diferença é que para os neoliberais, o problema da produtividade deve ser resolvido pelas forças de mercado.

Assim, o Estado deve atuar no sentido de garantir o incremento da produtividade nacional. Aliás, a forma de atuação deve incidir diretamente nas questões monetárias, assegurando um ambiente de inflação controlada e um câmbio desvalorizado, que garanta a pauta exportadora de commodities do Brasil.

No campo monetário, a política de controle inflacionário deve estar aliada a uma política que possa "preservar a paridade do poder de compra de moeda nacional relativamente às outras moedas, com a qual o equilíbrio externo fica mais ou menos garantido." ${ }^{157}$ Linha adotada não apenas por Gudin, mas também por Bulhões, que afirmara que "o Estado assegura a disciplina econômica e incentiva os investimentos, quando se preocupa em manter os preços isentos de interferências monopolísticas ou de desequilíbrios monetários." 158

No mais, a ideia de que qualquer medida estatal que interferisse no livre jogo do mercado se estendia, por óbvio, às políticas redistributivas. Assim, pautas como reforma agrária, recomposição da massa salarial e qualquer outra forma de distribuição de renda, seriam taxadas como inúteis . Eugênio Gudin afirmava que

"se se proporcionar a posse da terra ao homem do campo que não tem saúde, que não sabe ler, que não sabe semear, cultivar, fertilizar,

\footnotetext{
${ }^{156}$ BIELSCHOWSKY, Ricardo. Pensamento econômico brasileiro, op. Cit., p. 53.

${ }^{157}$ BIELSCHOWSKY, Ricardo. Pensamento econômico brasileiro, op. Cit., p. 68.

${ }^{158}$ BULHÕES, Octávio Gouvêa de. Economia e política econômica. Rio de Janeiro: Livraria Agir Editora, 1960, p. 83.
} 
combater as pragas etc, e que não dispõe de crédito, ele não terá outra solução senão a de vender a terra que recebeu" ${ }^{159}$

Esta mesma linha de raciocínio se estenderia para todas as ações governamentais que, de alguma forma, pretendessem redistribuir a renda. Como toda a linhagem neoliberal, o mercado seria o melhor alocador de recursos e qualquer interferência seria ineficiente e economicamente injusta.

A linhagem neoliberal, liderada desde a década de 1930 por Eugênio Gudin e Octávio Bulhões, semeou os ideais que até hoje são largamente identificáveis dentro do espectro político brasileiro. O ressurgimento desta política se dará nos anos 1990, porém, desta vez seus defensores ocuparão a máquina estatal, colocando em prática o que Gudin já prescrevera: a única intervenção estatal séria no mercado deveria se dar através do Banco Central, perseguindo metas de inflação e fixando a taxa de juros.

Passamos agora a estudar o pensamento desenvolvimentista-nacionalista, cuja maior expressão foi, sem dúvida, Celso Furtado.

\subsubsection{O Desenvolvimentismo de tipo nacionalista}

O levantamento, e seu resultado, são recorrentes. Sempre que um jornal, periódico acadêmico, associação ou entidade ligada ao estudo da economia se propõe a perguntar aos grandes economistas brasileiros sobre quem seria o maior expoente das ciências econômicas brasileiras, o nome vencedor é um só: Celso Furtado.

Furtado deixou o que talvez seja o maior legado em termos de produção teórica sobre o desenvolvimento econômico no Brasil. Como professor ou pesquisador, foi afiliado à Cambridge, à Sorbonne, Yale e Columbia. Formado em Direito, integrou o quadro técnico do DASP logo após o bacharelado. De lá, seguiu para a França, como bolsista, para doutorar-se em economia. Sob a chefia de Prebisch, integrou a Cepal, em 1949. Fundou e presidiu a Superintendência do Desenvolvimento do Nordeste (SUDENE), além de ter

\footnotetext{
${ }^{159}$ GUDIN, Eugênio. Preliminares sobre a reforma agrária. Digesto Econômico, São Paulo, 18 (162), novembro-dezembro de 1961, p. 69.
} 
fundado e dirigido o Ministério do Planejamento.Tudo isso sem nunca deixar de pensar e escrever sobre o desenvolvimento do Brasil.

Celso Furtado pode ser considerado o maior representante do estruturalismo cepalino no Brasil. Suas contribuições foram decisivas para construir o corpo teórico da Comissão Econômica para a América Latina.

Se a Cepal nunca possuiu um único entendimento sobre os processos de superação do subdesenvolvimento, ao menos a ideia de coordenação estatal para superação do estado de coisas que permeavam todos os países da região deve ser atribuída a ele.

Porém, a maior contribuição de Celso Furtado foi mesmo dada ao Brasil. Seu nacionalismo - muitas vezes mal interpretado - deve ser visto como um desejo intrínseco de dar ao país o status de nação verdadeiramente soberana. Talvez por ser bacharel em Direito - à época não existiam no país cursos de economia - Celso Furtado transpôs às suas teses o desejo inseparável de um país desenvolvido, para o mundo e principalmente para seu povo.

Como lembra Bielschowsky, Furtado - e todos os outros economistas da linha desenvolvimentista nacionalista -se fiavam, dentre outras coisas

\footnotetext{
"na ideia de que só através da coordenação estatal seria possível internalizar os centros de decisão sobre os destinos da economia brasileira e romper com as relações de submissão ao comando tradicional dos países desenvolvidos; ou seja, só através de decidida ação estatal seria possível a emancipação econômica nacional."160
}

Desta forma, os economistas de matriz desenvolvimentista do tipo nacionalista primaram pelo entendimento que só a industrialização, aliada com reformas estruturais no seio da sociedade brasileira, promovidas e dirigidas pelo Estado, seriam capazes de dar ao país um cenário de superação do subdesenvolvimento endêmico.

Fundado nas ideia de Keynes, de quem assimilou a centralidade do mercado interno como dinamizador da produção e renda, Furtado e seu grupo de "nacionalistas" somaram às suas teses as ideias de Prebisch e Paul Singer sobre a deterioração dos termos de troca e do

${ }^{160}$ BIELSCHOWSKY, Ricardo. Pensamento econômico brasileiro, cit. p. 134. 
papel geopolítico das nações subdesenvolvidas como exportadoras de commodities às economias centrais.

O modelo desenvolvimentista nacionalista se foca prioritariamente na ideia de desenvolvimento a partir de dentro, ou seja, primeiramente pela constituição de um forte mercado interno. À época de sua formulação, o projeto descrevia a industrialização nacional para substituição das importações, forte ponto de estrangulamento ao desenvolvimento nacional e condição para a implementação do que Prebisch e os economistas cepalinos convencionaram chamar de desenvolvimento para dentro.

A situação em que países como o Brasil se encontravam foi chamada de industrialização periférica, problemática na essência, pois além de não possuir correspondentes históricos, ainda contava com um passado recente de industrialização espontânea.

Assim, a ideia de desenvolvimento nacional passava pela realização de um processo pleno de industrialização, transformando o mercado interno em pólo dinâmico da economia. $\mathrm{O}$ Brasil do início da segunda metade do século XX era altamente dependente da exportação de commodities agrárias para manter algum nível de atividade econômica. Industrializar o país de forma plena passava a ser então um moto contínuo, que visava garantir o que se chamou de internalização dos centros de decisão econômica.

Dentro do grupo de economistas desenvolvimentistas nacionalistas, que compartilhavam tais teses, destacamos aqui Rômulo de Almeida, Américo B. Oliveira e Evaldo Cunha Lima. A partir de agora, este tópico seguirá analisando cada um dos principais temas defendidos por esta corrente: internalização dos centros de decisão econômica; mercado interno; industrialização; planejamento; presença do capital internacional desde que coordenado pelo Estado, e seu ativismo no setor produtivo.

O processo de industrialização dos países sul-americanos é em boa medida concomitante. Como aponta Maria da Conceição Tavares, as sucessivas crises econômicas nacionais e internacionais, cuja maior expressão foi a prolongada crise da década de 1930, criaram as 
condições para que se rompesse com o modelo de desenvolvimento econômico baseado em economias agro-exportadoras e passassem a um novo modelo. ${ }^{161}$

Lembra a economista que o processo de desenvolvimento que surgia tinha como foco a substituição das importações. Para ela, o processo de substituição das importações deve ser compreendido como uma resposta às restrições do comércio exterior, que procurou repetir aceleradamente - ainda que em condições históricas distintas - a experiência da industrialização dos países desenvolvidos. ${ }^{162}$

Neste cenário, como lembra Werner Baer, a industrialização deste período tende a ser decorrente de choques do setor externo. Sem incorrer em processo, e sim em forma de surtos, a substituição de importações tem sua matriz na escassez de oferta no mercado internacional. ${ }^{163}$

Particularmente no fim da década de 1920, os constantes choques externos haviam causado sérias complicações à economia nacional. Como apontou Celso Furtado, ao fim daquela década, a situação de crise internacional direcionou a produção para o mercado interno, que se beneficiou rapidamente do momento. Em 1932, a produção industrial do país já superava todos os anos anteriores, sendo que em 1935, o investimento líquido já era maior do que os anos anteriores à crise. ${ }^{164}$

A importância desta anotação não é apenas histórica. Ao formular sobre o tema, como apontou Bielschowsky ${ }^{165}$, Celso Furtado não apenas iria trazer uma nova narrativa aos fatos. Muito de sua tese sobre industrialização e desenvolvimento tem suas bases na análise

\footnotetext{
${ }^{161}$ TAVARES, Maria da Conceição. Da substituição de importações ao capitalismo financeiro: ensaios sobre economia brasileira. 2a edição. Rio de Janeiro: Zahar, 1973, p. 33

162 TAVARES, Maria da Conceição. Op. Cit., p. 35.

163 BAER, Werner. A industrialização e o desenvolvimento econômico do Brasil. 7ạ Edição. Rio de Janeiro: Editora FGV, 1988 p. 11 e 12.

${ }^{164}$ FURTADO, Celso. Formação econômica do Brasil: edição comemorativa: 50 anos. São Paulo: Companhia das Letras, 2009, p. 283

${ }^{165}$ Ricardo Bielschowsky indica que mais do que a maior obra da literatura econômica publicada entre 1930 e 1964, Formação econômica do Brasil é também um esquadrinhamento metodológico que servirá ao economista durante toda sua vida. Para mais informações: BIESLCHOWSKY, Ricardo. Pensamento econômico brasileiro, cit. p. 162 e seguintes.
} 
deste período histórico. Não à toa, o título do capítulo de Furtado para narrar o processo é chamado de deslocamento do centro dinâmico. ${ }^{166}$

Passamos a analisar a tese sobre industrialização no pensamento furtadiano. Como visto, Furtado e toda a Cepal admitem a priori as ideias de Prebisch sobre a deterioração dos termos de troca, a lógica centro-periferia e, principalmente, o processo de industrialização das periferias, que naturalmente tende ao atraso em relação às economias centrais. ${ }^{167}$

Para Furtado, a força motriz para o desenvolvimento do Brasil seria o deslocamento do centro dinâmico e a transferência dos centros de decisão da economia.

Em linhas gerais, Celso Furtado entendia como deslocamento do centro dinâmico da economia nacional a mudança da matriz econômica brasileira. Ou seja, para promover o desenvolvimento, a economia nacional deveria deixar de ser agrária e se tornar industrial. Apenas com uma indústria homogênea - seja em termos de extensão do parque industrial, seja em termos de igualdade tecnológica tanto em relação a todos os setores da economia quanto com seus concorrentes externos - o Brasil alcançará o estágio de nação desenvolvida. 168

Melhor dizendo, o Brasil deveria propiciar um ambiente onde o maior centro formador de capital fosse a indústria, e não o setor agro-exportador.

Já por centros de decisão, entendeu Celso Furtado como sendo os pólos detentores do capital. Em economias de matriz agrária-exportadora os centros de decisão do investimento estão, via de regra, nas mãos do capital estrangeiro. Ou seja, para Furtado, as economias dos países subdesenvolvidos não possuem autonomia (no setor privado) e soberania (no caso público) para decidirem onde alocar seus recursos. Tal situação corrobora para a manutenção do quadro de subdesenvolvimento. ${ }^{169}$

\footnotetext{
${ }^{166}$ FURTADO, Celso. Formação econômica do Brasil, cit., p. 278.

${ }^{167}$ BIELSCHOWSKY, Ricardo. Pensamento econômico brasileiro, cit. p. 139-140.

${ }^{168}$ FURTADO, Celso. Desenvolvimento e subdesenvolvimento, cit., p. 214.

169 Para uma leitura sintética de como este processo se deu no Brasil, vide: FURTADO, Celso.

Desenvolvimento e subdesenvolvimento, cit., p. 215.
} 
Mais objetivamente, os centros de decisão econômica são os pólos detentores da demanda. Em uma economia baseada na exportação de produtos agrícolas, os centros de decisão são os mercados internacionais, que adquirem os produtos exportados.

Em um cenário deste, o desenvolvimento será o que os cepalinos convencionaram chamar de "desenvolvimento para fora", ou seja, de economias que se desenvolverão de forma dependente do mercado externo. Além de estarem ao sabor dos humores das economias desenvolvidas que adquirem seus produtos, tais nações sempre dependerão da importação dos bens industriais que não possuem, para atender as demandas de seu mercado interno. 170

Ao alterar o centro de decisão econômica, trazendo-o para dentro do país, reconfigura-se o projeto de desenvolvimento, para o chamado "desenvolvimento para dentro". Neste modelo, o objetivo é criar um círculo virtuoso de consumo do mercado interno, promovendo a industrialização nacional que abasteça a sua população com bens de consumos antes só adquiridos no exterior. Nesta esteira, a criação de empregos, via indústria, garantirá a elevação do nível de vida, mantendo o ciclo virtuoso. ${ }^{171}$

Internalizar os centros de decisão econômica pressupunha a adoção de uma estratégia de industrialização que privilegiasse a proteção e promoção do mercado interno. Estratégico na propulsão do modelo de desenvolvimento furtadiano, o mercado interno seria não dinamizar a economia e garantir a estabilidade econômica e de preços: para Celso Furtado, a criação e manutenção de um mercado interno robusto seria capaz de absorver até os insumos agrícolas antes destinados à exportação. Tal situação leva a uma menor instabilidade de preços do que quando sujeito apenas aos humores do mercado internacional. $^{172}$

Vê-se então que a internalização dos centros de decisão econômica é conceito chave na tese furtadiana de desenvolvimento de tipo nacionalista. Ratifica-se aqui a ideia de que internalizar os centros de decisão da economia é migrar a fonte de demanda do mercado

\footnotetext{
${ }^{170}$ RODRÍGUEZ, Octavio. O estruturalismo latino-americano. Op. Cit., p. 81.

${ }^{171}$ Para uma descrição deste processo na economia nacional, vide: FURTADO, Celso. A pré-revolução brasileira. Rio de Janeiro: Fundo de Cultura, 1962, p. 109 a 112.

172 Idem ibidem, p. 110.
} 
internacional, para o mercado interno. Trata-se de processo que ao tempo em que fortalece o pátio industrial, cria e consolida o mercado interno.

Como ele mesmo apontou, o processo de desenvolvimento deve levar à endogeneidade, que nada mais é "senão a faculdade que possui uma comunidade humana de ordenar o processo acumulativo em função de prioridades por ela mesma definidas." 173

É imperioso ressaltar que, seguindo a linha de Prebisch, ${ }^{174}$ a teoria de Celso Furtado admite que o quadro de subdesenvolvimento é um "processo histórico autônomo, e não uma etapa pela qual tenham, necessariamente, passado as economias que já alcançaram grau superior de desenvolvimento." 175

Isto significa que a situação de manutenção do subdesenvolvimento não é condição histórica e sim, geopolítica. Desta forma, a alteração dos centros de decisão da economia, retirando das economias internacionais e inserindo-a em um contexto nacional, jamais ocorrerá naturalmente, sem concentração de esforços.

Desta forma, a questão a ser trazida seria como proporcionar tal internalização, dado que nenhum fator externo operará pela mudança deste cenário.

A forma de propiciar esta internalização será a industrialização. Esta posição não é nova e foi compartilhada por outra corrente da época: os desenvolvimentistas "não nacionalistas". Desde o início do século XX, Roberto Simonsen defendia que apenas com a industrialização o Brasil superaria seu estado de subdesenvolvimento endêmico.

Como ele mesmo apontou,

"se é certo que a base da estrutura econômica do Brasil deve repousar na cultura da terra, não é menos certo que no estágio atual da civilização, a independência econômica de uma grande nação, seu prestígio e sua atuação política como povo independente no concerto das nações só

\footnotetext{
${ }^{173}$ FURTADO, Celso. Cultura e desenvolvimento em época de crise. 2a edição. São Paulo: Paz e Terra, 1984, p. 108.

${ }^{174}$ Para a assimilação das teses de Prebisch, vide: FURTADO, Celso. Teoria política do desenvolvimento econômico. 10a Edição. São Paulo: Paz e Terra, 2000, p. 152 e 153.

${ }^{175}$ FURTADO, Celso. Desenvolvimento e subdesenvolvimento, cit, p. 161.
} 
podem ser tomados na consideração devido, possuindo este país um Parque Industrial eficiente, na altura do seu desenvolvimento agrícola.",176

Celso Furtado também caminhava neste sentido, apontado haver uma "elevada correlação entre desenvolvimento e industrialização." 177

Ou seja, desde o início do século XX já havia um elevado número de economistas e pensadores que se alinhavam com a premente necessidade de se superar um país exportador de commodities agrícolas e passar efetivamente para uma economia industrial.

Independentemente do entendimento sobre como seria o processo de industrialização e se este novo parque industrial serviria ao mercado interno ou ao mercado internacional, inúmeros políticos, economistas e afins concordavam sobre a necessidade de um Brasil industrial. A questão seria então, como proporcionar esta marcha contínua para a industrialização, dado que ate então o Brasil só havia visto pequenos surtos esparsos e descoordenados.

A resposta a este questionamento sob a ótica furtadiana também já foi dada: a internalização dos centros de decisão da economia brasileira.

Toda a questão sobre a internalização de tais centros via industrialização recairiam então sobre o principal indutor deste processo. Para Furtado, o único agente capaz de realizar esta tarefa seria o Estado.

$\mathrm{Na}$ ideia do Estado como difusor central do processo de desenvolvimento, este não seria apenas como coordenador ou indutor indireto. No pensamento furtadiano, o planejamento certamente tem papel central, mas não só. Acreditava

\footnotetext{
"que o sucesso da industrialização brasileira dependia fortemente do controle que os agentes nacionais pudessem ter sobre as decisões fundamentais à economia do país. Pensava, por isso, ser indispensável uma ampla participação estatal na captação e alocação de recursos, através de um sistema de planejamento abrangente e de pesados

${ }^{176}$ SIMONSEN, Roberto. Orientação industrial brasileira. In: CARONE, Edgard (org.). Evolução industrial do Brasil e outros estudos. São Paulo: Editora Nacional: Editora USP, 1973, p. 55

${ }^{177}$ FURTADO, Celso. Teoria e política do desenvolvimento econômico. 10ạ edição. São Paulo: Paz e Terra, 2000, p. 244.
} 
investimentos estatais. Considerava também necessário um controle do capital estrangeiro." 178

Desta forma, a ação do Estado no processo de industrialização seria dada em duas frentes: como financiador da atividade industrial-capitalista (via indireta de participação), e por meio do planejamento global da economia nacional, dirigindo os processos econômicos e participando diretamente da atividade industrial de base (via direta de participação).

É o próprio autor quem indica que "como o empresário individual não está em condições de romper a inércia inicial que oferecem as estruturas subdesenvolvidas, torna-se necessária uma ação promovida por uma autoridade central.", 179

Quanto ao financiamento, o pensamento furtadiano se distanciava do cepalino, na medida em que achava que a entrada de capitais externos significa a criação de um fluxo permanente de rende de dentro para fora do país. ${ }^{180}$ Ao mesmo tempo em que a Cepal manteve historicamente a postura de defesa da participação do capital estrangeiro na economia, Furtado entendia que o fluxo de entrada de dinheiro internacional acarretaria no envio permanente de moeda para fora, via remessa de lucros e dividendos das multinacionais às suas matrizes.

Por isso, entendia que o financiamento da atividade econômica deveria ser feito internamente, apontando para uma participação ativa do Estado neste processo. Até porque, dado que o país necessitava de investimentos em grande monta, apenas o Estado seria capaz de cumprir tal tarefa.

Quanto ao planejamento, a ideia do desenvolvimentismo nacionalista repousava diretamente na lógica de um planejamento global da economia. Enquanto os desenvolvimentistas "não nacionalistas" entendiam que o planejamento deveria ser pensado de forma estanque, de acordo com a necessidade de cada segmento da economia, Furtado e seus desenvolvimentistas nacionalistas apontavam para um modelo global, que pensasse a economia brasileira como um todo. ${ }^{181}$

\footnotetext{
${ }^{178}$ BIELSCHOWSKY, Ricardo. Pensamento econômico brasileiro, cit. p. 151.

${ }^{179}$ FURTADO, Celso. Teoria e política do desenvolvimento econômico. Cit., p. 285.

${ }^{180}$ BIELSCHOWSKY, Ricardo. Pensamento econômico brasileiro, cit. p. 151

${ }^{181}$ Idem ibidem, p. 153.
} 
O modelo de planejamento global foi concebido e idealizado pela Cepal. Seu funcionamento se baseava nas premissas de desenvolvimento como sendo um processo amplo, com pressupostos e decorrências que influenciavam a economia como um todo. Desta forma, todo o ato de planejamento da economia seria um processo único, onde o Estado estivesse disposto a intervir onde achasse necessário, para a condução do processo desenvolvimentista. ${ }^{182}$

Para o autor, o planejamento seria então uma técnica a serviço de uma política de modificação das estruturas econômicas. Segundo Celso Furtado, a complexa coordenação de decisões, necessária para a superação do subdesenvolvimento, somente é viável em um quadro de planejamento. ${ }^{183}$

A questão do planejamento do desenvolvimento industrial guarda importância em outra medida: a inovação e o progresso técnico.

Para Furtado, o avanço tecnológico da indústria e da sociedade como um todo era fundamental. Entretanto, Celso Furtado procurou se afastar da concepção schumpeteriana de inovação. Não porque não acreditasse nela, mas sim por considerá-la incompleta.

Em seu Desenvolvimento e subdesenvolvimento, Furtado aponta que a tese de Schumpeter sobre o empresário inovador, na forma que foi apresentada, não é outra coisa se não uma teoria do lucro. ${ }^{184}$ Menos pela inovação - a qual Furtado concebia como tão fundamental a ponto de ser uma das maiores características diferenciadoras entre países periféricos e centrais - e mais pelo descolamento do empresário do mundo, as teses schumpeterianas sobre desenvolvimento seriam falhas.

Ao prescrever o seu modelo de desenvolvimento, Schumpeter haveria primeiramente prescrito uma tese vaga, dado que o conceito de desenvolvimento só pressupunha as chamadas "novas combinações". Além de apenas olhar o processo de desenvolvimento pelo lado da produção, Joseph Schumpeter entendia que o empresário é um sujeito a-

\footnotetext{
182 BIELSCHOWSKY, Ricardo. Pensamento econômico brasileiro, cit., p. 153.

${ }^{183}$ FURTADO, Celso. Teoria e política do desenvolvimento econômico. Cit., p. 301.

${ }^{184}$ FURTADO, Celso. Desenvolvimento e subdesenvolvimento. Cit., p. 69 a 76.
} 
histórico e sempre se comportaria como agente de mercado tendente a competir e inovar. Ou seja, a ação do empresário seria autônoma da realidade que o cerca.

Se essa hipótese se verificasse, o empresário nunca abusaria de sua posição social. A presunção de que seu comportamento seria sempre em direção à inovação pressupõe que o empresário não agirá como rentista, retirando seus dividendos do processo produtivo e inserindo-o em situações onde não invista mais inovação, e sim, no lucro. ${ }^{185}$

Por tudo isso, deixar o desenvolvimento às forças do mercado, para Furtado, na melhor das hipóteses levaria a uma situação de crescimento sem desenvolvimento. Apenas com um planejamento aprofundado, pelo Estado, o desenvolvimento - inclusive tecnológico ocorrerá. Até porque, como ele mesmo apontou ao se referir ao sucesso do desenvolvimento japonês, "o crescimento do mercado interno é muito mais consequência deste dinamismo tecnológico do que fruto dos antagonismos sociais próprios da sociedade capitalista." 186

Por fim, resta ainda a participação do Estado na atividade econômica propriamente dita. Furtado e os nacionais-desenvolvimentistas, entendiam que para assegurar o contínuo crescimento econômico, nos moldes nacionalistas, o Estado poderia, e em alguns casos deveria, assumir a ação empresarial.

Basicamente, Furtado entendia que as empresas estatais deveriam atuar no sentido de fomentar o desenvolvimento nacional. Desta forma, apostava principalmente na ação estatal no setor de base, fomentando o desenvolvimento. ${ }^{187}$

Com as linhas aqui referenciadas, é possível inferir que o desenvolvimento econômico para os desenvolvimentistas de matriz nacionalista absorveram várias teses sobre o desenvolvimento.

\footnotetext{
${ }^{185}$ Idem ibidem, p. 73.

${ }^{186}$ FURTADO, Celso. Criatividade e dependência, cit. p. 87.

${ }^{187}$ FURTADO, Celso. Introdução ao desenvolvimento: enfoque histórico-estrutural. 3a edição. São Paulo: Paz e Terra, 2000, p. 113.
} 
A primeira é a noção de Hirschman, sobre o crescimento desequilibrado. Para Furtado, por exemplo, a atuação do planejamento estatal seria exatamente para dirimir a tendência natural deste tipo de crescimento, que seria próprio da condição periférica.

Outro item a ser observado é a criação dos pólos de crescimento, de Perroux. Concomitante ao desequilíbrio de Hirschman, Perroux apontava que a criação de pólos de crescimento, como setores industriais, ensejaria em um processo sistemático de desenvolvimento, onde a criação do novo pólo resolveria deficiências estruturais da economia nacional, gerando novos gargalos. Para resolver estes novos entraves, criar-seiam novos pólos, até que houvesse a homogeneização daquele setor da economia. Este pensamento está na base das proposições cepalinas, visto que trata-se de processo inerente ao chamado modelo de desenvolvimento para dentro.

Esta breve análise do pensamento nacional-desenvolvimentista teve como escopo mostrar suas principais teses, aqui resumidas no pensamento de Celso Furtado, que sem dúvida, foi a maior expressão do desenvolvimentismo nacionalista em todos os tempos.

Portanto, uma vez cumprida esta tarefa, seguimos agora para outro campo do desenvolvimentismo: o modelo "não-nacionalista", cuja maior expressão foi Roberto Campos.

\subsubsection{O Desenvolvimentismo de tipo "não nacionalista"}

Viu-se que Celso Furtado não foi bem sucedido apenas dentro do campo acadêmico. Suas passagens por Cambridge, Yale, Columbia e Sorbonne, como pesquisador ou professor, dão alguma dimensão da relevância de seu pensamento para a discussão sobre desenvolvimento econômico mundo afora.

Além da criação da SUDENE, suas passagens pelo Ministério do Planejamento durante o governo João Goulart, e pelo Ministério da Cultura durante o período da distensão política, entre 1986 e 1988, mostram como Furtado teve relevância como homem público, marcando sua presença na política de Estado do Brasil. 
Enquanto Celso Furtado se tornou referência mundial para assuntos sobre desenvolvimento, outro economista, não menos primoroso, foi o responsável por boa parte da política desenvolvimentista do Estado brasileiro. Após o golpe de 1964, o governo central caminhou rapidamente no sentido de adotar as prescrições de Roberto Campos no que tangia às políticas desenvolvimentistas.

Eugênio Gudin relatou que Ragnar Nurkse, certa vez, haveria dito que Roberto Campos foi o aluno de economia mais brilhante que passara por Columbia em anos. ${ }^{188}$ Campos, além de economista formado naquela faculdade, foi diplomata e talvez um dos mais influentes teóricos sobre o desenvolvimento no Brasil.

Já foi dito que Furtado espalhou suas teorias pelos maiores centros universitários do mundo. Comparando-o com Roberto Campos, percebemos que o economista formado em Columbia viu sua teoria ser mais aplicada do que Furtado.

Roberto Campos e seu modelo desenvolvimentista "não nacionalista" foi o vencedor da disputa entre os campos desenvolvimentistas na década de 1960. Com o golpe de Estado, em 1964, o poder ditatorial se aproximou progressivamente de seu pensamento, tendo basicamente adotado-o em suas linhas mestras.

Crítico ácido do marxismo, das esquerdas e dos regimes maoísta e stalinista, defendeu a ditadura da qual fez parte. Criticou ao máximo a intervenção do Estado com textos liberais, na mesma linha de Gudin ou Bulhões. Como membro do governo Castelo Branco, atuou como Ministro do Planejamento, relegando em parte sua obra e admitindo alguns corolários tipicamente esquerdistas, como a própria ideia de planejamento.

Idiossincrasias à parte, conforme aponta Bielschowsky, Roberto Campos

"foi, sem dúvida, o economista da nova ordem do Brasil, que passava da velha estrutura agrário-exportadora à nova estrutura da economia industrial internacionalizada. Campos apostou na industrialização pela via da internacionalização de capitais e do apoio do Estado - e ganhou." 189

\footnotetext{
${ }^{188}$ BIELSCHOWSKY, Ricardo. Pensamento econômico Brasileiro, cit. p. 104.

${ }^{189}$ BIELSCHOWSKY, Ricardo. Op. Cit., p. 105.
} 
No campo teórico, definir tanto Roberto Campos quanto o chamado desenvolvimentismo "não nacionalista" não é tarefa tão simples. Campos e seus adeptos defendiam sérias restrições à participação do Estado - via empresas estatais - na economia, ao mesmo tempo em que se colocavam como ávidos defensores do planejamento econômico como ferramenta fundamental para o desenvolvimento.

Outra característica do campo desenvolvimentista "não nacionalista" foi seu tamanho. Como lembra Bielschowsky, apesar da grande influência de seus escritos, o campo liderado por Campos não possuía grande número de adeptos, tendo como figuras de expressão economistas como Ary Torres, Glycon de Paiva e Lucas Lopes. ${ }^{190}$

Se por lado os "não nacionalistas" contavam com pequeno número de pensadores, em relação aos desenvolvimentistas nacionalistas ou mesmo os socialistas, a herança da qual se apropriaram para formular suas teses foi forte. Inicialmente próximos do liberalismo de Gudin, foi a apropriação de parte do pensamento de Roberto Simonsen que garantiu aos “não nacionalistas” muito do estofo teórico que posteriormente viriam a postular.

Simonsen pode ser considerado um dos fundadores da ideia de desenvolvimento e industrialização do país. Em seu Evolução industrial do Brasil e outros estudos, o autor sintetiza seu pensamento, afirmando que "a industrialização de um país como o Brasil é indispensável para que ele possa atingir um estágio de alta civilização." 191

Ao longo de toda sua trajetória, Simonsen se preocupou em construir um pensamento de superação do estágio de subdesenvolvimento nacional, por via da industrialização. O economista era enfático ao defender - ao contrário de seus sucessores - a participação ativa do Estado neste processo. Analisando a conjuntura da década de 1930, Simonsen indica "não existir a ideia de nação sem protecionismo." 192

\footnotetext{
190 Idem ibidem, p 103.

${ }^{191}$ SIMONSEN, Roberto. Evolução industrial do Brasil e outros estudos. São Paulo: Companhia Editora Nacional, 1973, p. 288.

192 SIMONSEN, Roberto. À margem da profissão. São Paulo: São Paulo Editora, 1932. Apud. BIELSCHOWSKY, Ricardo. Pensamento econômico Brasileiro, cit. p. 84.
} 
Se Simonsen se notabilizou por semear as ideias do desenvolvimento e da industrialização com participação estatal, Roberto Campos procurará absorver apenas a ideia da necessidade fundamental da industrialização.

Este será o pensamento chave dos economistas e pensadores identificados como desenvolvimentistas "não nacionalistas": a defesa, desde a década de 1950, de um processo de industrialização internacionalista, com planejamento estatal e sem nenhuma - ou muito pouca - participação deste. Mesmo no campo do planejamento, os "não nacionalistas" se prontificavam a atacar o modelo vigente, implementado pelos desenvolvimentistas estruturalistas, o planejamento integral. Ao contrário, apontavam para o planejamento seccional, que consistiria no planejamento de alguns poucos setores da economia, “considerados prioritários por seu poder intrínseco de geração de crescimento." 193

A tese do planejamento seccional atenderia a outro clamor, de matriz liberal. Ao subdividir a atividade planejadora do Estado, os "não nacionalistas" reduziriam substancialmente a intervenção, ainda que indireta, na economia. Conforme apontara o próprio Roberto Campos,

"[O] planejamento seccional teria ainda, argúi-se, a vantagem de circunscrever a área de intervenção governamental ao mínimo necessário para o desenvolvimento econômico, considerando esta que é de alguma importância quando a eficiência técnica dos órgãos públicos deixa a desejar." 194

Esta linha proto-liberal também não seria suficiente para enquadrar Roberto Campos dentre os neoliberais. Eugênio Gudin, por exemplo, refutava qualquer intervenção estatal para a promoção do desenvolvimento, ainda que indireta. O mercado seria o senhor absoluto e autônomo para promover o desenvolvimento brasileiro.

Por outro lado, os "não nacionalistas" tenderam a pensar o processo de industrialização sob dois vieses: ao mesmo tempo em que entendiam a necessidade premente de um processo de substituição de importações pela industrialização, rejeitavam a ideia de um crescimento

\footnotetext{
193 BIELSCHOWSKY, Ricardo. Pensamento econômico brasileiro, cit. p. 111.

${ }^{194}$ CAMPOS, Roberto. Planejamento do desenvolvimento econômico de países subdesenvolvidos. Digesto Econômico, São Paulo, abril de 1952, p. 25.
} 
desequilibrado, nos moldes de Hirschman. Entediam, na linha de Ragnar Nurkse ${ }^{195}$, que o modelo de desenvolvimento nacional a ser adotado deveria respeitar o ritmo compatível com o equilíbrio econômico, sem causar grandes discrepâncias inflacionárias, fiscais ou monetárias.

Como indicou o então Ministro do Planejamento no texto de seu "Programa de Ação Econômica do Governo (PAEG)",

“[A] ação governamental, nos sistemas políticos democráticos, deve orientar-se no sentido do estabelecimento das condições que assegurem a maior eficiência possível ao funcionamento da economia de livre empresa, ou seja, do sistema de preços." 196

Isto não significou que Campos discordou da noção de desequilíbrio no processo de desenvolvimento. Para o autor, a ideia de desenvolvimento equilibrado encontrava limites nela mesma, dado que crer neste cenário seria crer na ideia de que a oferta seria permanentemente elástica enquanto se moldaria à todas as variações da demanda. Ou seja, jamais a economia nacional, em um modelo de crescimento equilibrado, teria algum tipo de choque, seja pelo lado da oferta, quanto da demanda. ${ }^{197}$

Tudo porque sua concepção de desenvolvimento era bastante heterodoxa. Além de combinar elementos monetaristas - como um controle mais ativo nos processos inflacionários decorrentes da industrialização - Roberto Campos admitiria que a noção de inflação estrutural também existia, não descartando por completo o pensamento furtadiano. Como ele mesmo apontou,

\footnotetext{
"inclinava-me também, mais que os mestres neoliberais, a aceitar a ênfase cepalina sobre substituições de importações, admitindo certa validade nos argumentos cepalinos sobre os fatores adversos, que tornariam a industrialização uma saída necessária para os desequilíbrios externos." 198
}

\footnotetext{
${ }^{195}$ Ragnar Nurkse, já citado aqui, é considerado até hoje uma das maiores autoridades em desenvolvimento econômico. Sua tese se focava na noção de desenvolvimento equilibrado, a partir do big push. Ao que interessa aqui, cumpre lembrar que ele foi um dos teóricos mais combatidos por Hirschman, que como visto, advogou em prol do crescimento desequilibrado.

${ }^{196}$ BRASIL. Ministério do Planejamento e Coordenação Econômica. Programa de ação econômica do governo - 1964-1966, 2a edição. Brasília, maio de 1965, p.13

${ }^{197}$ CAMPOS, Roberto. Inflation and balanced growth. In: ELLIS, H. (ed.) Economic development for Latin America. Londres: Macmillan, 1961. Apud. BIELSCHOWSKY, Ricardo. Pensamento econômico brasileiro, cit. p. 115.

${ }^{198}$ CAMPOS, Roberto. A lanterna na popa: memórias. Rio de Janeiro: Topbooks, 1994, p. 169.
} 
Ainda, o desenvolvimentismo "não nacionalista", se possuía bons olhos ao capital internacional, era avesso à presença de empresas estatais apenas nos casos onde o mercado não manifestasse interesse. Este pensamento casa, em boa medida, com a lógica da ditadura militar, que atuava no mesmo sentido.

Este ecletismo foi então a marca do pensamento desenvolvimentista "não nacionalista". Calcado por um pragmatismo que variou ao longo do tempo, os economistas aqui representados tentaram conciliar os interesses nacionais com a necessidade de inserção do país na economia internacional, que garantiria a captação de financiamento em nações desenvolvidas, aceitando a presença do capital e indústria estrangeira no país.

Por tudo isso, conforme apontou Reginaldo Teixeira Peres, é impossível filiar Roberto Campos em uma corrente protecionista ou liberal. ${ }^{199}$

Após esta breve digressão, é possível perceber que os traços mais marcantes da linha político-econômica aqui descrita são: defesa da industrialização nacional, planejada parcialmente pelo Estado e executada - sempre que possível - na sua integralidade pelo setor privado; alta permissividade estatal com a presença do capital internacional, seja na indústria, seja no sistema financeiro; controle inflacionário, mesclando as prescrições neoliberais ao mesmo tempo em que admitia a noção de inflação estrutural, ou seja, de que a situação de constante importação de bens de consumo, aliada à situação de exportador de matérias-primas, causaria naturalmente pressões inflacionárias.

Uma vez analisada as três proposições sobre o projeto de desenvolvimento nacional, segue-se agora para o próximo capítulo.

Retornando às ciências jurídicas, o foco da próxima parte desta dissertação será proceder uma revisão bibliográfica sobre o artigo 219 da Constituição Federal. Em suma, a ideia agora será apresentar o que a academia jurídica produziu de mais relevante sobre a inserção do mercado interno enquanto parte integrante do patrimônio nacional.

\footnotetext{
199 PEREZ, Reginaldo Teixeira. Pensamento político de Roberto Campos. Rio de Janeiro: Ed. FGV, 1999, p.
} 119. 
Trata-se de tema pouco explorado dentro do Direito, o que refletirá em um problema objetivo, a falta de fontes para dar densidade à revisão bibliográfica aqui proposta. 


\section{CAPÍTULO 3. DISCURSOS SOBRE O MERCADO INTERNO E O PATRIMÔNIO NACIONAL: ALGUMAS ANÁliSES DO ARTIGO 219 DA CONSTITUIÇÃO FEDERAL}

Após a reconstrução histórica dos discursos sobre o desenvolvimento nacional e suas principais vertentes, esta pesquisa se focará em apontar quais seriam as possíveis interpretações para o artigo 219.

O principal objetivo deste capítulo é trazer alguns entendimentos sobre o significado do dispositivo analisado nesta pesquisa. Assim, o que for aqui acumulado servirá de padrão comparativo com a hipótese desta pesquisa. A referência apresentada neste capítulo servirá como baliza teórica para que se possa comparar o que foi apresentado como hipótese e o que alguns grandes nomes das ciências jurídicas nacionais apresentam como significado do referido dispositivo.

De plano, lembra-se que o artigo em análise não foi um dos mais explorados, seja pelo direito constitucional, seja pelo direito econômico. Em que pese tal fato servir como um limitador natural para a pesquisa, a apresentação das teses sobre o artigo 219 da Constituição Brasileira se torna ainda mais relevante, uma vez que sem elas, a pesquisa partiria de um voo cego.

Esta parte da dissertação serve como base introdutória para o que será tentado no capítulo 4: a análise do texto constitucional selecionado, permitindo que ao final seja apresentado um esboço de entendimento do que seria o artigo 219. Será com o substrato aqui apresentado que a análise do referido artigo, à luz das teses sobre o desenvolvimento econômico, será feita.

3.1. Visões de uma economia liberal: Tercio Sampaio Ferraz e José Afonso da Silva

Não foram muitos os que se propuseram a escrever sobre o a defesa do mercado interno pela sua inserção dentro do patrimônio nacional. Não só, dentre estes poucos, muitos trataram do assunto de forma tributária, ou seja, na medida em que se propuseram a 
discutir temas correlatos, a análise do artigo 219 surgiu em seus estudos, ensejando suas considerações. Foi o caso de Tercio Sampaio, cuja discussão decorre de outra, sobre a regulamentação da ordem econômica.

Outra dificuldade inerente a um processo de pesquisa como este, com poucas fontes, diz respeito à aglutinação dos escritos por temas comuns. Não apenas pela dificuldade do processo de organização do produto escrito da pesquisa, há de se levar em conta que o estudo do tema foi feito basicamente por constitucionalista, que não costumam ser muito afetos às ciências econômicas.

De toda forma, optamos por fazer um recorte mais amplo que, grosso modo, reflete a visão econômica implícita nos textos aqui analisados. Por mais que possuam importantes diferenças dentro de suas considerações sobre a forma como a economia nacional deva ser organizada, tanto Tercio Sampaio quanto José Afonso da Silva parecem fazer bastante referência em uma economia lastrada fundamentalmente no livre mercado. Por tal motivo, ambos encontram-se no mesmo tópico deste capítulo.

Ainda, lembra-se aqui que esta dissertação não perdeu de vista o disposto na Carta Constitucional de 1988, especialmente nos artigos $1^{\circ}$ e 170 , que expressamente defendem a livre iniciativa e a livre concorrência respectivamente como fundamento da República e princípio da ordem econômica nacional. Entretanto, a valoração do livre mercado como pedra de toque da intervenção do Estado na economia tende a variar conforme o autor, e, no caso dos dois citados, seus textos aqui estudados fazem importante referência ao conceito de livre mercado.

Desta forma, ainda que com várias diferenças, ambos parecem estar mais próximos do que os demais, ao menos no que tange a discussão sobre o tema aqui abordado.

\subsubsection{O Estado como regulador econômico: Tercio Sampaio Ferraz Jr.}

A discussão sobre o conteúdo implícito ao artigo 219 da Constituição Brasileira está, como é possível imaginar, atrelada à discussão sobre o próprio modelo de organização da economia nacional eventualmente previsto em nossa Constituição. 
A motivação para esta afirmação é simples: analisar um dispositivo que vincula o mercado interno como sendo parte integrante do patrimônio nacional e que garante seu fomento para a promoção do desenvolvimento econômico e social, torna-se tarefa se não impossível, ao menos incompleta sem que seja entendido qual seja o contexto econômico que ele está inserido.

Assim, a análise deste artigo não pode estar descolada da compreensão do que a Carta Magna brasileira prescrevera para a ordem econômica como um todo.

Ao final do próximo capítulo, esta dissertação tratará com afinco da inserção da proteção do mercado interno dentro de um contexto econômico-constitucional mais amplo. Por hora, esta informação é importante para pavimentar o que Tercio Sampaio Ferraz Jr. prescreve sobre a preservação do mercado interno, no contexto do artigo 219 da Constituição Brasileira.

Tercio Sampaio Ferraz Jr. se propõe a analisar a preservação do mercado interno como parte integrante do patrimônio nacional por um viés pouco usual: será com o fito de discutir o comportamento dos agentes de mercado em um modelo de livre concorrência e livre mercado, que o professor tecerá seus comentários acerca do artigo aqui analisado.

A proposição de Sampaio Ferraz Jr. é discutir algumas possibilidades de regulamentação da ordem econômica pelo Estado. Inicialmente diferindo o conceito de livre mercado da ideia de livre iniciativa ${ }^{200}$, trata o autor de demonstrar que na livre concorrência, organizada dentro do livre mercado, os agentes econômicos podem ter ao menos dois comportamentos: o de competição e o de cooperação.

Em tese, em uma economia de livre concorrência, o comportamento desejado - e mais comum - seria o da competição entre os concorrentes. Tentando maximizar seu lucro, os

\footnotetext{
${ }^{200}$ Para o autor, enquanto o livre mercado pressupõe um mercado que se auto-regule, ou seja, que seja um livre formador de preços e natural alocador de recursos. Enquanto isso, a livre iniciativa seria a possibilidade da pessoa de direito privado atuar no livre mercado. Ainda, lembra o professor que perante a livre iniciativa (e à própria livre concorrência) a ideia de livre mercado é neutra, dado que este se configura apenas como espaço para a conformação dos preços e alocação dos recursos. In FERRAZ Jr. Tercio Sampaio. Regulamentação da Ordem Econômica. In, Cadernos de Direito Constitucional e Ciência, - Janeiro-Março de 1997, ano 5, no 18, RT, São Paulo, pp. 95-98
} 
concorrentes devem sempre, em um mercado competitivo, buscar um maior grau de eficiência, seja produtiva, seja em seus custos de transação, seja através da inovação ou mesmo na diminuição de sua margem de lucro. Os típicos comportamentos competitivos são aqueles efetivamente esperados em uma economia concorrencial. Quando não ocorrem, lembra o professor que o Estado, via repressão ao abuso do poder econômico, tem meios para evitar que práticas anti-competitivas perdurem no tempo.

Entretanto, apesar da conduta esperada ser sempre a de competição entre os agentes econômicos, não é estranho que se observe situações diversas, mesmo em um mercado altamente competitivo.

Em vários casos, é possível se observar as condutas cooperativas, que não necessariamente infrinjam a ordem econômica. Em verdade, como lembra o autor, é impossível que exista um mercado livre onde a livre concorrência é exercida que não subsistam comportamentos cooperativos. Desde práticas comuns que visem maximizar a eficiência de um grupo de agentes do mercado até situações de cooperação involuntária ${ }^{201}$, é impossível que haja um mercado que não conte com ações cooperativas entre seus concorrentes.

Entretanto, apesar da conduta cooperativa não ser necessariamente anti-competitiva a priori, é fundamental que se tenha em mente as distorções que este tipo de comportamento termina por criar no mercado. Guiadas principalmente pelo ganho de eficiência alocativa, ou seja, a diminuição de custos de produção (ou assemelhado) de um agente econômico, os comportamentos cooperativos tendem a posicionar apenas uma parte dos concorrentes de determinado segmento de mercado. Desta forma, a cooperação tende a se tornar um privilégio, ferindo o princípio da livre concorrência.

Nestas situações, lembra o autor que o Estado tem diante dele sempre duas alternativas: a primeira, como dito, é a repressão ao abuso do poder econômico, nos moldes citados acima para a manutenção de um mercado guiado pela livre concorrência.

\footnotetext{
${ }^{201}$ Como o investimento de um representante patronal (ou um dos membros do Sistema S) em qualificação maciça de trabalhadores. Neste caso, nenhum deles agiu enquanto agente de mercado para cooperar com outro. Foi a contribuição pecuniária destes a um órgão para-estatal que propiciou o investimento em formação profissional, que ajudará a todos os agentes de mercado.
} 
A segunda forma de controle das condutas cooperativas, conforme lembra Tercio Sampaio, é através de autorizações do Estado, via órgão de controle da atividade concorrencial. ${ }^{202}$ Tais autorizações são emitidas nos casos de termos de acordo, joint ventures, contratos de distribuição e afins. Em todos esses casos, os concorrentes cooperam para um fim comum a ambos. Será sob a análise destes atos de concentração que o Estado, via Conselho Administrativo de Defesa Econômica (CADE), tem a possibilidade de manter a livre concorrência, sem necessariamente atuar na esfera repressiva.

Para o autor, será exatamente neste ponto que o artigo 219 surgirá em seus estudos. A justificativa constitucional para a manutenção deste campo de atuação do Estado - por meio do CADE - reside na preservação do mercado interno enquanto parte do patrimônio nacional. Ou seja: para o autor a questão do mercado interno é abordada através da manutenção da livre concorrência.

Vê-se então que a proposta de análise da preservação do mercado interno está sob uma ótica bastante liberal, no sentido de que o cerne da discussão reside na manutenção do livre mercado. Nas palavras de Tercio Sampaio,"ao integrar o mercado interno ao patrimônio nacional, ele tem que ser gerido." ${ }^{203}$ Ou seja, ao menos sob este aspecto, a preservação do mercado interno é antes de tudo um instrumento de manutenção da economia de mercado. Trata-se de instrumento de incentivo ao capitalismo concorrencial, sem uma necessária ligação com o desenvolvimento.

O aparente pragmatismo liberal-regulacionista parece não estar presente unicamente neste texto. Em seu "Zona Franca de Manaus e incentivos fiscais do setor de informática", o referido professor parece trilhar caminho semelhante. Conforme o autor, é no artigo 219 "que está o fundamento para o incentivo dos setores econômicos de alta tecnologia.",204

Em que pese o dispositivo constitucional ser abordado em ambos os textos, em determinados casos concretos não é impossível retirar dos escritos um ponto comum: nos dois casos, o autor se vale de uma lógica instrumentalista do dispositivo.

\footnotetext{
${ }^{202}$ FERRAZ Jr. Tercio Sampaio. FERRAZ Jr. Regulação da ordem econômica, cit.

203 Idem ibidem.

${ }^{204}$ FERRAZ Jr. Zona Franca de Manaus e incentivos fiscais do setor de informática. In. Direito Constitucional. Liberdade de fumar, privacidade, Estado, direitos humanos e outros temas. Barueri: Manole, 2007, p.328.
} 
De fato, a apreciação está longe de ser rasa e tem profunda conexão com a realidade. Tanto a análise do dispositivo como instrumento de preservação da legitimação constitucional para a intervenção do Estado no domínio econômico, quanto no caso de concessão de privilégio tributário que vise o desenvolvimento regional, são faces reais possíveis de atuação do Estado para a preservação do mercado interno como sendo parte integrante do patrimônio nacional.

A questão a ser destacada é que nos dois casos, o instrumentalismo do artigo 219 da Constituição brasileira é meio para a preservação da economia de mercado, sob uma ótica concorrencial. Como se viu, a hipótese deste trabalho é que o artigo analisado parece estar mais ligado não à manutenção de um status quo econômico e sim a um projeto de desenvolvimento para a nação. O artigo 219 parece se comportar mais como uma prescrição programática da Constituição de 1988 e não como apenas um respaldo instrumental para a manutenção da economia de mercado.

De outra monta, a análise do dispositivo constitucional sob uma ótica liberal parece não ser apenas exclusividade do professor Tercio Sampaio Ferraz Jr. Outro autor de peso, o constitucionalista José Afonso da Silva, ainda que com contornos mais humanistas, parece ter considerações semelhantes sobre o artigo em análise.

\subsubsection{O mercado enquanto espaço social: a posição de José Afonso da Silva}

Tercio Sampaio Ferraz Jr. se vale da defesa do mercado interno para justificar a intervenção do Estado no domínio econômico. De fato, qualquer análise econômica que leve em conta a preservação do mercado interno contará com a utilização da manutenção de um capitalismo concorrencial e da concessão de privilégios tributários como formas de preservação do mercado de uma determinada nação.

Entretanto, tal análise não leva em conta o caráter estratégico que o mercado interno pode ter em um processo de desenvolvimento. Tais instrumentos tendem muito mais a manter uma estrutura econômica do que necessariamente ampliá-la. 
José Afonso da Silva parece iniciar seu percurso analítico do artigo 219 da Constituição Brasileira em um escopo bastante diverso, para dar entendimento razoavelmente parecido sobre o dispositivo aqui analisado.

De início, cumpre observar que Afonso da Silva indica que o artigo em questão estaria melhor localizado na Constituição se estivesse incluído no capítulo sobre a ordem econômica, dado seu conteúdo. Conforme o autor, o art. 219 "deveria estar entre as regras da ordem econômica, mais do que ciência e tecnologia, na qual a intervenção no domínio econômico encontra importante fundamento para o controle do mercado interno." ${ }^{205}$ Esta posição parece se alinhar com os comentários de Tercio Sampaio, que indicou coisa semelhante em seu artigo aqui analisado.

Tais considerações terminam por não levar em conta que a questão do desenvolvimento científico e tecnológico é item fundamental para o desenvolvimento econômico nacional. Como já demonstrara Schumpeter, e mesmo a escola desenvolvimentista sul-americana, a inovação tem papel central no desenvolvimento nacional. É através do empresário (ou mesmo o Estado, como apontaram alguns desenvolvimentistas) inovador que os ganhos de capital poderão efetivamente garantir o desenvolvimento econômico nacional.

Desta forma, em que pese a preocupação formal, a inclusão do artigo no capítulo responsável por tratar das questões de ciência e tecnologia parece não estar tão descolado de um viés econômico, ainda que indireto.

Feita esta ressalva, passa-se agora a analisar qual seria o entendimento de José Afonso da Silva sobre o tema.

Talvez a primeira colocação objetiva sobre o tema faça referência ao sentido extraeconômico que o mercado possui. Para Afonso da Silva, o mercado não é apenas um local de trocas econômicas, sendo antes de tudo, um espaço social. ${ }^{206}$ Isto significa, entre outras coisas, que o mercado é um fenômeno da existência humana e inerente à conformação de nossa espécie em sociedades. Citando Weber, o autor aponta que o livre mercado - que

\footnotetext{
${ }^{205}$ SILVA, José Afonso da. Comentário Contextual á Constituição de 1988, 6ạ edição. São Paulo: Malheiros, 2009, p. 822.

${ }^{206}$ Idem ibidem, p. 823.
} 
seria aquele não sujeito às normas éticas - é considerado por toda a Ética como "coisa abjeta entre os humanos",207

Esta conceituação de mercado será o fio condutor do autor. Será a partir do entendimento de que o mercado é um dado da realidade social humana que o artigo 219 será estudado.

Será visto adiante que dentro da historiografia econômica exista quem divirja radicalmente desta posição, como Fernand Braudel. Para um dos fundadores da escola francesa dos anais, o mercado em sua forma de espaço virtual de trocas, regido por leis próprias, parece mais ser uma construção político-histórica do que algo inerente às sociedades humanas.

Para o que interessa neste momento, é esta a pedra angular do constitucionalista brasileiro sobre a questão do mercado interno. Para José Afonso da Silva, a confirmação desta análise está também no próprio texto constitucional.

Segundo o autor, o artigo 219 da Constituição é a própria confirmação jurídica de que o mercado deve ser valorado não só sob seu viés econômico. Ao inscrever o mercado interno dentro do patrimônio nacional, o legislador constituinte teria conferido ao mercado interno status supra-econômico.

Nas palavras de José Afonso da Silva,

"A Constituição dá ao mercado interno um valor para além desse seu significado econômico, ao integrá-lo no patrimônio nacional. Com esse sentido, o mercado adquire valor constitucional, que nos dá sua dimensão social, sob a ideia de que, em seu sentido puramente econômico, pode fixar preços, mas não pode fixar valores sociais, porque estes é que têm que fixar a natureza e limites dele" 208

Vemos assim que para o autor a valoração constitucional do mercado dá a ele a possibilidade de limitação jurídica, especialmente para evitar que este fixe valores sociais.

Após estas considerações, o autor se põe então a discutir o que seria a previsão constitucional do artigo aqui analisado. Para ele,

\footnotetext{
${ }^{207}$ Idem ibidem, p. 823.

${ }^{208}$ SILVA, José Afonso da. Op. Cit., p. 823.
} 
"[a] Constituição, considerados os fundamentos e princípios da ordem econômica (art. 170), as bases da ordem social (art. 193) e o mercado como patrimônio nacional, em última análise, não adotou pura e simplesmente uma economia de mercado, mas uma economia social de mercado, que seja compatível com o respeito e a vigência dos direitos sociais" 209

Ou seja, ao inscrever na Constituição o mercado interno dentro do patrimônio nacional, primou o legislador por organizar o país dentro do que seria uma economia social de mercado.

Sem aprofundar muito, indica José Afonso da Silva que a economia social de mercado seria aquela que se estabeleça em compatibilidade com os direitos sociais, também previstos na mesma Constituição de 1988.

A proposição do autor guarda a semelhança com Tercio Ferraz Jr. na medida em que erige a economia de mercado como fonte principal do artigo 219. Para o constitucionalista, a inserção do artigo analisado tem referência na organização econômica capitalista do Estado brasileiro, que deve, em última análise, respeitar os direitos sociais, sendo assim uma economia social de mercado.

Faz-se aqui, ainda, a ressalva de que Cláudia Lima Marques, Bruno Miragem e Lucas Lixinski parecem, em certa medida, acompanhar Afonso da Silva. Seguindo o prescrito pelo referido constitucionalista, a professora gaúcha indica que "essa parece ser a melhor visão do mercado interno ou interpretação do art. 219 do CF/1988: um mercado nacional com função social, cultural e econômica." 210

Apesar do esforço do eminente constitucionalista brasileiro e um dos principais articuladores da Constituição cidadã, a análise em questão padece de alguns problemas.

O primeiro deles talvez seja a confusão do conceito de mercado com o de mercado interno. Sem adiantar a discussão que será travada no próximo capítulo, que tratará de elucidar alguns conceitos para a conformação de um esboço interpretativo do artigo 219, o fato é

\footnotetext{
${ }^{209}$ Idem ibidem, p. 823.

${ }^{210}$ MARQUES, Cláudia Lima; MIRAGEM, Bruno; LIXINSKI, Lucas. Desenvolvimento e Consumo - Bases para uma Análise da Proteção do Consumidor como Direito Humano. In: PIOVESAN, Flávia \& SOARES, Inês Virgínia Prado. Direito ao Desenvolvimento. Belo Horizonte: Ed. Forum, 2010, p.210.
} 
que mercado e mercado interno são coisas distintas. Inicialmente porque a palavra mercado é, mesmo dentro da economia, bastante polissêmica e seu significado guarda relação com o momento histórico e a forma de organização econômica à época vigente.

Assim, definir o termo mercado unicamente como espaço virtual de trocas regido sob leis como a da oferta e demanda e a da maximização do bem estar individual é algo bastante reducionista.

Porém, mesmo que se tome como único significado para o termo o conceito acima citado, resta lembrar que mercado interno possui uma delimitação física, relacionado aos limites da nação. Enquanto mercado é algo virtual, o mercado interno, além de ser constituído pelo mercado citado, ainda é composto de fatores como o conjunto de consumidores de uma nação, por exemplo.

O segundo problema é aquele que já fora citado na conceituação de Tercio Sampaio Ferraz Jr: tratar o mercado interno de forma instrumental. Nos dois casos, os autores não imputam ao conceito a participação em algo maior. Para José Afonso da Silva, o mercado interno sendo integrante do patrimônio nacional é um dado da realidade que para funcionar corretamente, deve apenas estar inscrito dentro dos ditames constitucionais - os quais estão inclusos os direitos sociais.

Tal colocação, ainda que de maneira diversa do que previra Tercio Ferraz Jr., acaba por conferir ao mercado interno um papel instrumental, no sentido de que é parte de um estado de coisas e deve o Direito se preocupar apenas com seu correto funcionamento.

Por fim, há ainda um último questionamento a ser feito, que diz respeito à valoração social que o mercado poderia exercer sobre a humanidade. Item que também será abordado ainda que de forma breve - no próximo capítulo, a questão mercado como sendo mediador das relações sociais parece ser algo inerente ao processo de produção do capitalismo. Ao estabelecer todas as mediações das relações sociais por meio do pagamento pecuniário (e principalmente o trabalho humano), o modo de produção capitalista responde pelo encargo de ter introduzido o dinheiro como o mediador último das relações humanas. Até mesmo a 
honra pode ser compensada pelo pagamento de certa quantia em dinheiro, via de regra arbitrada pelo judiciário.

Isto significa dizer que o mercado termina por ser o organizador das valorações humanas, econômicas ou não. Com seus vícios e virtudes, é o mercado que, dentro do modo de produção capitalista, termina por ditar os valores humanos. Isso não quer dizer que o ser humano esteja amarrado à tal condição, mas o fato é que o Direito termina por servir mais como linha auxiliar desta característica do capitalismo do que necessariamente um freio balizador da sociedade. Novamente, existem inúmeras exceções a esta proposição. Porém, no geral, elas tendem sempre à confirmar a regra.

Visto isso, caminhamos agora para outra aproximação do conteúdo ora estudado sob outro viés, mais próximo da hipótese desta pesquisa.

\subsection{Defesa do capital nacional: a posição de Manoel Gonçalves Ferreira Filho}

Conforme anteriormente debatido no capítulo 2, boa dose das discussões sobre os rumos da política econômica do país recaíram sobre a questão da participação ou não do capital estrangeiro no processo de desenvolvimento brasileiro. Desde a primeira onda de industrialização do país até o final da ditadura militar do Brasil, a questão da entrada de capitais estrangeiros na economia nacional foi tema que dividiu opiniões sobre a política econômica a ser seguida.

O alcance desta discussão no campo econômico já foi visto anteriormente. Cabe apenas ressaltar que o nacionalismo econômico trouxe consequências para o campo do Direito. Seja no Direito Econômico, seja no Direito Constitucional ou mesmo no campo da Teoria do Estado, a entrada de capital estrangeiro no mercado interno nacional dividiu opiniões. Independentemente de matiz ideológica, o nacionalismo econômico foi abarcado tanto por progressistas, socialistas, liberais e conservadores. O regime de exceção brasileiro, por exemplo, se valeu fortemente do nacionalismo ao longo de sua trajetória. 
Desta forma, não é de se estranhar que ao discutir a integração do mercado interno enquanto parte do patrimônio nacional, posições não necessariamente progressistas façam referência ao controle do capital externo como mote da política econômica nacional. É neste escopo que se encontra a opinião de Manoel Gonçalves Ferreira Filho.

Para o constitucionalista, a intenção do legislador constitucional ao prescrever o disposto no artigo 219 foi de preservar o mercado interno para o capital nacional. Ferreira Filho se vale do texto para afirmar que ao integrar o mercado interno dentro do patrimônio nacional, a Constituição Federal terminou por privilegiar o setor empresário brasileiro em detrimento do internacional. Para o autor, o texto seria "a fundamentação última para as restrições à participação do capital estrangeiro no mercado brasileiro."211

Seguindo nesta linha, Manoel Gonçalves Ferreira Filho conclui que "se o 'mercado interno integra o patrimônio nacional', ou seja, o mercado é nosso, justo, na visão nacionalista, que ele seja reservado para os brasileiros, de modo a viabilizar o desenvolvimento nacional, a sua autonomia tecnológica etc." 212 .

Se o texto não esclarece até que ponto Ferreira Filho compartilha do entendimento que defende, o que fica claro com sua última ressalva é que a própria Constituição conteria um dispositivo limitador à concessão em demasia de privilégios ao capital nacional. Para o constitucionalista, "Se, todavia, pelo viés do incentivo do mercado interno, supôs-se que a lei federal pudesse ampliar as vantagens conferidas à empresa brasileira de capital nacional, isso não é correto em face, exatamente, da redação do art. 171 da Constituição",213.

Sabe-se que o artigo 171 fora revogado no ano da publicação de sua obra, esvaindo de efeito os comentários de Ferreira Filho sobre este dispositivo. Entretanto, tal comentário parece deixar claro que para o autor, apenas as diferenciações conferidas no dispositivo hoje revogado seriam aceitáveis dentro da legislação brasileira. ${ }^{214}$

\footnotetext{
${ }^{211}$ FERREIRA FILHO. Manoel Gonçalves. Comentários à Constituição Brasileira de 1988, vol 4. São Paulo: Saraiva, 1995, p.92.

212 Idem ibidem, p. 92.

${ }^{213}$ Idem ibidem, p. 92.

${ }^{214} \mathrm{O}$ artigo 171 da Constituição de 1988 foi revogado pela Emenda Constitucional no 6, de 1995. Seu objetivo era garantir uma reserva de mercado à nascente indústria de tecnologia nacional.
} 
Desta forma, ao mesmo tempo em que guarda referência no nacionalismo econômico, Ferreira Filho mantém um viés liberal, dado que ao se valer do artigo 171 como dispositivo limitador da diferenciação do capital estrangeiro, termina também por garantir um entendimento bastante restritivo sobre a preservação do mercado interno imbricado ao patrimônio nacional.

Esta abordagem também é acompanhada em parte por Ives Gandra da Silva Martins. Apesar de aprofundar a discussão, tentando diferenciar quais mercados estariam presentes - ou não - na prescrição do dispositivo em comento, Ives Gandra indica que o "mercado" em referência, trata daquele "de densidade econômica, isto é, aos relacionados com a

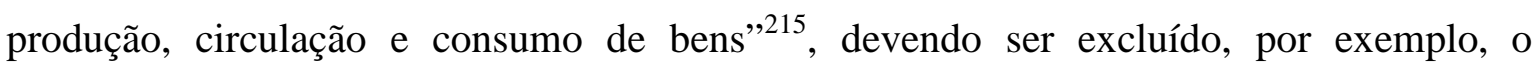
mercado de bens culturais.

Apesar deste grau de diferenciação, Gandra Martins parece concordar com a linha mais liberal-nacionalista, na medida em que, defende o dispositivo como instrumento para o desenvolvimento nacional, ao passo que garante amplo funcionamento da economia de mercado. ${ }^{216}$

Art. 171. São consideradas:

I - empresa brasileira a constituída sob as leis brasileiras e que tenha sua sede e administração no País;

II - empresa brasileira de capital nacional aquela cujo controle efetivo esteja em caráter permanente sob a titularidade direta ou indireta de pessoas físicas domiciliadas e residentes no País ou de entidades de direito público interno, entendendo-se por controle efetivo da empresa a titularidade da maioria de seu capital votante e o exercício, de fato e de direito, do poder decisório para gerir suas atividades.

$\S 1$ ㅇ - A lei poderá, em relação à empresa brasileira de capital nacional:

I - conceder proteção e benefícios especiais temporários para desenvolver atividades consideradas estratégicas para a defesa nacional ou imprescindíveis ao desenvolvimento do País;

II - estabelecer, sempre que considerar um setor imprescindível ao desenvolvimento tecnológico nacional, entre outras condições e requisitos:

a) A exigência de que o controle referido no inciso II do "caput" se estenda às atividades tecnológicas da empresa, assim entendido o exercício, de fato e de direito, do poder decisório para desenvolver ou absorver tecnologia;

b) Percentuais de participação, no capital, de pessoas físicas domiciliadas e residentes no País ou entidades de direito público interno.

§ 2o - Na aquisição de bens e serviços, o Poder Público dará tratamento preferencial, nos termos da lei, à empresa brasileira de capital nacional

${ }^{215}$ MARTINS, Ives Gandra. In: BASTOS, Celso Ribeiro; MARTINS, Ives Gandra. Comentários à Constituição do Brasil. 2a Edição. São Paulo: Saraiva, 2000. p. 868, vol. VIII.

${ }^{216}$ Idem ibidem, p. 868 
Se é fato que a preservação do mercado interno nos termos do dispositivo aqui analisado traz como consequência a possibilidade de concessão de privilégios à empresa nacional, também é um dado da realidade que tais medidas compõem apenas uma parte das possibilidades da utilização deste instrumento como forma de política econômica. Reduzir o espectro do campo de ação do Estado pela descrição do artigo 219 apenas como meio de garantir vantagens à empresa de capital nacional é se esquecer de todo o papel que o Estado pode assumir enquanto motor do desenvolvimento nacional.

Tudo porque, ao garantir que o mercado interno deve ser promovido e incentivado, a Constituição pode ter afiançado não apenas instrumentos de estímulos ao capital nacional (ou desestímulos ao capital internacional). De fato, o legislador constituinte pode ter conferido ao Estado brasileiro instrumentos jurídicos para a superação do subdesenvolvimento endêmico do país, dando a possibilidade da construção de um projeto nacional que busque desenvolver o país "de dentro para fora".

O entendimento meramente descritivo sobre a questão do mercado interno como objeto de regulação de lei inferior parece não se ater apenas aos comentários de Manoel Gonçalves Ferreira Filho. Alexandre de Moraes aponta, sem muito aprofundamento, que o artigo 219 seria apenas uma norma a ser concretizada pela edição de legislação infraconstitucional para integrar o mercado interno ao patrimônio nacional, com o fim de promover o desenvolvimento econômico e social brasileiro. ${ }^{217}$ Esta linha descritiva é adotada também por Pinto Ferreira que segue exatamente o mesmo roteiro. ${ }^{218}$

Retomando a linha proposta por Ferreira Filho, veremos que a análise abstrata do dispositivo aqui analisado tende a se aproximar mais da hipótese deste trabalho, de que o artigo 219 da Constituição Federal está inserido em um contexto maior, que desvela um projeto específico de desenvolvimento nacional.

Porém, antes que se remeta à análise dos elementos que compõem o artigo e as considerações dela decorrentes, mister buscar analisar os autores que tenderam a interpretá-lo como sendo algo mais próximo do depreendido na introdução desta pesquisa.

\footnotetext{
217 MORAES, Alexandre de. Constituição do Brasil interpretada, 7ạ edição. São Paulo: Atlas, 2007, p. 2169.

${ }^{218}$ FERREIRA, Pinto. Comentários à Constituição Brasileira. São Paulo: Saraiva, 1995, p.207
} 
3.3. A superação do subdesenvolvimento pela reafirmação da soberania nacional: o mercado interno como motor do desenvolvimento econômico

O privilégio constitucional ao mercado, como lembra Eros Roberto Grau, parece ser inequívoco. ${ }^{219}$ É o próprio autor do artigo analisado nesta presente dissertação que faz questão de lembrar que, apesar de ser expressamente citado apenas no artigo 219 da Constituição, a livre iniciativa e a livre concorrência conferem ao mercado papel privilegiado organizador da economia nacional.

Entretanto, o "pai" do referido artigo é categórico ao lembrar que o dispositivo confere um dever ao Estado. Não necessariamente atuando com um intervencionismo dirigente ${ }^{220}$, lembra o professor que o referido artigo termina por fundamentar a possibilidade de intervenção estatal na economia, sem, contudo, coagir o Estado para tal feita.

A questão a ser analisada, porém, estaria focada nos motivos que ensejariam ao Estado, intervir, da forma que melhor entender, no domínio econômico.

Como se sabe, o disposto no artigo aqui estudado foi ${ }^{221}$ e é objeto de constantes controvérsias. A pouca quantidade de material publicado sobre o tema não impede que haja um grande embate entre os que se dispuseram a estudá-lo. Dentre as críticas, preponderam aquelas que indicam como "estatismo tecnocrata-xenófobo, cuja lista tragicômica se encerra com a afirmação de que o mercado interno integra o patrimônio nacional." 222

Para Eros Grau e vários outros autores, o artigo 219 parece prescrever uma receita conjugada para a superação do estágio subdesenvolvido do Brasil. Ricardo Camargo lembra que o conteúdo ideológico presente ao dispositivo não pode ser denegado de sua

\footnotetext{
${ }^{219}$ GRAU, Eros Roberto. A ordem econômica na Constituição de 1988 (Interpretação e Crítica). 14 ạ edição. São Paulo: Malheiros, 2010, p. 259.

${ }^{220220}$ A intervenção estatal por direção, nas palavras de Eros Grau, refere-se à ação estatal que "exerce pressão sobre a economia, estabelecendo mecanismos e normas de comportamento compulsório para os sujeitos da atividade econômica em sentido estrito. In: GRAU, Eros. Op. Cit., p. 147.

${ }^{221}$ Grau, Eros. Op. Cit., p. 147.

222 MOREIRA NETO. Diogo de Figueiredo. O Estado e a economia na Constituição de 1988. Revista de Informação Legislativa, Brasília: Senado Federal, v. 26, no 102, abr/jun 1989, p. 18.
} 
análise. Desta forma, ao se debruçar sobre a questão do mercado interno, devemos ter em conta que o incentivo do mercado interno e sua integração junto ao patrimônio nacional tem fim específico: o desenvolvimento sócio-econômico brasileiro. ${ }^{223}$

Neste ponto, aliás, lembra o autor gaúcho que a inserção do termo desenvolvimento, pressupõe o entendimento de que o desenvolvimento econômico "implica necessariamente a de uma progressão em direção a uma situação considerada melhor, mais desejável que a atual." 224

Como apontado anteriormente neste capítulo, ao passo que alguns autores procuraram dar ao artigo aqui analisado apenas um caráter instrumental, garantindo meios para a intervenção do Estado na economia, outros buscam dar ao texto um sentido nacionalistaliberal, na medida em que enfatizam o livre-mercado como sentido último da organização econômica nacional.

Ainda, subsistem aqueles que, ao dar um caráter desenvolvimentista ao dispositivo, fazem questão de demarcar que a aplicação do artigo seria, em um primeiro momento, exclusivo à ciência e tecnologia, podendo ser estendido posteriormente ao "mercado em geral".

É o que aponta Alexandre Veronese, ao comentar o artigo 219 da Constituição. Conforme aponta o autor, o artigo possuía inicialmente um objetivo específico, qual seja, "fixar a possibilidade normativa de uma restrição ao mercado interno, tendo em vista a necessidade de autonomia tecnológica." 225

Entretanto, vê-se que existem também os que procuram dar, dentro de uma leitura desenvolvimentista-nacionalista, um entendimento mais amplo ao artigo, uma vez que terminam por dar ao dispositivo um contexto mais amplo, menos instrumental ou mesmo descritivo. Além de Eros Grau e Ricardo Camargo, parecem acompanhar, ainda que apenas em certa medida, autores como Cláudia Lima Marques.

\footnotetext{
${ }^{223}$ CAMARGO, Ricardo Antônio Lucas. O mercado interno, o patrimônio público e o art. 219 da Constituição Brasileira de 1988. In: Direito Econômico e Direito Administrativo: o Estado e o poder econômico. Porto Alegre: Sergio Fabris Editor, 2006, p. 94.

${ }^{224}$ Idem ibidem, p. 93.

${ }^{225}$ VERONESE, Alexandre. Arts. 218 e 219. In: BONAVIDES, Paulo; MIRANDA, Jorge e AGRA, Walber Moura (Coords.). Comentários à Constituição Federal de 1988. Rio de Janeiro: Forense, 2009, p. 2319.
} 
Em que pese seguir o prescrito por José Afonso da Silva, Lima Marques indica também que há, por trás do dispositivo, uma incipiente noção - como Ricardo Camargo - de que o artigo 219 "estabelece ou fixa uma política de Estado." ${ }^{226}$ Assim, a autora indica haver uma conexão entre a noção de mercado como espaço social e sua integração em uma política maior, articulada com outras ações estatais ou mesmo dispositivos constitucionais.

Esta posição é inferida também por Fernando Fabris. Conforme o autor gaúcho,

"[O] disposto no artigo 219 da Constituição Federal ao adotar o princípio
da integração do mercado interno ao patrimônio nacional, por um lado,
representa a indicação de que a Constituição adotou um regime de
mercado, mas, por outro lado,..., ratifica os termos postos quando o
preceito expressamente declara diretamente que o mercado é o meio
capaz de viabilizar o desenvolvimento cultural e sócio-econômico, o
bem-estar da população e a autonomia tecnológica do país e,
indiretamente, a justiça social" 227

O ponto comum a ser percebido entre os autores referenciados neste tópico é o entendimento de que há, por trás do dispositivo analisado, mais do que uma mera norma programática que tenha como foco a disciplina do mercado interno. Desde Eros Grau até Fernando Fabris, todos parecem concordar que o mote do artigo 219 é um programa para a nação. Mais do que simples norma disciplinadora do mercado, os autores parecem convergir que há sim uma prescrição de uma política de Estado, maior do que simplesmente a reserva de mercado para o ramo da ciência e tecnologia nacional.

A questão a ser discutida se torna então, qual política de Estado fora prescrita pelo legislador constitucional.

A resposta mais óbvia e imediata, é que a política de Estado prescrita seria a da promoção do desenvolvimento econômico nacional. Como se verá adiante, os conceitos de desenvolvimento econômico, socioeconômico, econômico-cultural, são por demais amplos. A questão é saber, à qual política esta prática (do desenvolvimento) está ligada.

\footnotetext{
${ }^{226}$ MARQUES, Cláudia Lima; MIRAGEM, Bruno; LIXINSKI, Lucas. Desenvolvimento e consumo - bases para uma análise da proteção do consumidor como direito humano. Op. Cit., p.213.

${ }^{227}$ FABRIS, Fernando Smith. A noção jurídica de mercado no Direito brasileiro. Tese (Doutorado em Direito), UFRS, 2006, p. 3.
} 
Em vários casos aqui discutidos, os autores declaram enfaticamente que a integração do mercado interno enquanto parte do patrimônio nacional é conexa a um projeto de desenvolvimento nacional. Respeitando o entendimento de que a Constituição brasileira é uma constituição do tipo dirigente, estes autores parecem concordar que o legislador constitucional terminou por orientar um projeto de desenvolvimento nacional, em respeito aos artigos $3^{\circ}$ e 170 de nossa Constituição.

Como visto anteriormente, a história recente da discussão sobre a política econômica nacional criou várias vertentes para a concretização do desenvolvimento nacional. Dentre as apresentadas nesta dissertação, destacam-se o modelo furtadiano, organizado em torno da CEPAL e o modelo que Bielchowski classificou como o desenvolvimentismo nãonacionalista, cuja figura de maior expressão foi Roberto Campos.

Assim, restaria então saber primeiramente se a Constituição especificou em seu corpo algum modelo de desenvolvimento específico. Ainda, sendo a resposta ao primeiro questionamento positiva, qual seria ele.

A resposta ao primeiro questionamento parece ser positiva. Além de o texto constitucional apontar expressamente que o desenvolvimento nacional é objetivo da República, conforme o prescrito no artigo $3^{\circ}$, a Carta Constitucional parece dar vários sinais de que há um conjunto de regras que conectadas, indicam que há sim um modelo de desenvolvimento.

Gilberto Bercovici se prontificou a indicar em várias de suas obras que não só há um projeto de desenvolvimento econômico em nossa Constituição, como tal projeto é organizado em torno de um modelo específico.

As primeiras indicações do autor sobre o modelo programático de desenvolvimento previsto na Constituição de 1988 são colocadas no debate sobre desenvolvimento econômico e desigualdades regionais. Indica Bercovici que "a Constituição de 1988 é um instrumento capaz de promover, por meio da atuação do Estado, a transformação social., 228

\footnotetext{
${ }^{228}$ BERCOVICI, Gilberto. Desigualdades regionais, Estado e Constituição. São Paulo: Max Limonad, 2003, p. 314
} 
Em um segundo momento, o autor segue a evolução do seu pensamento. Ao tratar sobre a existência de um projeto nacional de desenvolvimento, indaga que "[A] opção do Brasil não é se integrar na globalização ou se isolar de modo autárquico, a questão fundamental é se a integração dar-se-á a partir dos objetivos nacionais ou não." 229

As primeiras linhas sobre a possível conexão entre o texto constitucional e um modelo específico de desenvolvimento surgirão de fato em outro texto. Ao sintetizar a política desenvolvimentista cepalina-furtadiana, Bercovici irá começar a desenhar as conexões entre o projeto de desenvolvimento prescrito no texto constitucional brasileiro e o modelo nacional-desenvolvimentista. Em seu Constituição econômica e desenvolvimento, o autor esquadrinha as interconexões entre ambos os projetos. ${ }^{230}$

Outra pista sobre qual o modelo de desenvolvimento econômico previsto na Constituição Brasileira é prescrita talvez por Gilberto Bercovici. Aduz o autor que "a Constituição de 1988 está voltada para um modelo de desenvolvimento específico, vinculado à experiência histórica brasileira: o modelo nacional-desenvolvimentista." 231

Esta posição é defendida em outros textos do autor. Seguindo as linhas de Eros Grau e Ricardo Camargo, Bercovici aprofunda o debate sobre qual modelo de desenvolvimento parece a Constituição ter prescrito. Ao contrário de Mansueto de Almeida, que afirma não ter a Constituição brasileira um modelo econômico claro ${ }^{232}$, Bercovici é taxativo ao apontar que a Constituição Brasileira se organiza em sua política econômica em torno do nacional-desenvolvimentismo.

Em outro momento, aprofunda seu posicionamento. Aponta o autor que "[A] política científica e tecnológica está vinculada à política de desenvolvimento. O que a Constituição

\footnotetext{
${ }^{229}$ BERCOVICl, Gilberto. Estado, soberania e projeto nacional de desenvolvimento. In: Revista LatinoAmericana de Estudos Constitucionais. Belo Horizonte: Del Rey, v. 1, no 1, 2003, p. 569.

${ }^{230} \mathrm{BERCOVICI}$, Gilberto. Constituição econômica e desenvolvimento: uma leitura a partir da Constituição de 1988. São Paulo: Malheiros, 2005, p. 45-68.

${ }^{231}$ BERCOVICI, Gilberto. Os princípios estruturantes e o papel do Estado. In: CARDOSO Jr., José Celso. A Constituição Brasileira de 1988 Revisitada: Recuperação Histórica e Desafios Atuais. Brasília: IPEA, 2009, p. 273.

${ }^{232}$ ALMEIDA, Mansueto. A CF/88 e as Políticas de Incentivo à CT\&I Brasileiras. In: CARDOSO Jr., José Celso. A Constituição Brasileira de 1988 Revisitada: Recuperação Histórica e Desafios Atuais. Brasília: IPEA, 2009, p. 216.
} 
de 1988 efetivou foi a plena incorporação da ciência e da tecnologia ao processo de superação do subdesenvolvimento e de dependência tecnológica."233

Ao demonstrar que a incorporação do avanço tecnológico é parte integrante do processo de desenvolvimento econômico, Bercovici faz mais do que demonstrar que talvez a inserção da discussão proposta junto ao artigo 219 esteja topograficamente bem situada junto ao capítulo da ciência e tecnologia da Constituição. De fato, tal colocação vai ao encontro de um determinado modelo de desenvolvimento, previamente discutido neste trabalho: o nacional-desenvolvimentismo, organizado em torno das ideia da CEPAL e que teve como maior expoente brasileiro o economista Celso Furtado.

Tal inferência é diretamente apontada no texto em referência. Conforme aduz Gilberto Bercovici, o conteúdo presente junto ao artigo aqui analisado "tem sua inspiração teórica na concepção de ‘desenvolvimento endógeno’ elaborada por Celso Furtado.” 234

Este posicionamento vai ao encontro do que já foi estudado aqui anteriormente. Conforme apontado, a teoria nacional-desenvolvimentista se calca, entre outros fatores, na internalização dos centros de decisão econômica, na dinamização e integração do mercado interno, com grande ênfase para o desenvolvimento tecnológico. ${ }^{235}$

Mais além, Bercovici lembra que "[A] expansão do mercado interno é entendida pela Constituição, particularmente pela leitura conjunta dos seus arts. $3^{\circ}$, II, 170 , I e 219 , como principal estratégia do de dinamismo econômico." 236

Esta posição coaduna em muito com a hipótese deste trabalho. Ao somar os preceitos constitucionais de uma Constituição Dirigente, do modelo CEPALino de desenvolvimento e da leitura extensiva da Constituição Econômica em sentido estrito da Carta de 1988, surgem os elementos que dão guarida ao entendimento de que o artigo 219 está inserido

\footnotetext{
${ }^{233}$ BERCOVICl, Gilberto. Ciência e inovação na Constituição de 1988. In:Revista dos Tribunais, v. 101, no 916, São Paulo: Revista dos Tribunais, 2012, p. 270.

${ }^{234}$ Idem ibidem, p. 285.

235 Celso Furtado se vale do exemplo da criação da indústria do petróleo para demonstrar como a internalização do centro de decisão econômica, via Estado, da produção petrolífera foi responsável pelo desenvolvimento econômico, científico e tecnológico no setor. In: FURTADO, Celso. Desenvolvimento e subdesenvolvimento. Rio de Janeiro: Contraponto, 2009, p. 216.

${ }^{236}$ BERCOVICl, Gilberto. Ciência e inovação na Constituição de 1988. Op. Cit., p. 286.
} 
não apenas na ordem econômica da Constituição Brasileira. Ao que tudo indica, o dispositivo em referência está contextualizado em um ideário maior, com uma significação específica sobre o que deveria ser o projeto de desenvolvimento do país.

Porém, para que esta hipótese possa subsistir, há de se levantar alguns conceitos presentes no artigo aqui estudado. Possivelmente ao se analisar alguns conceitos-chave do artigo 219, surgirão novos elementos que possam ratificar a hipótese que fora apresentada até aqui. É o que será feito a seguir. 


\section{CAPÍtULO 4. ESTUdO DO ARTIGO 219 DA CONSTITUIÇÃO FEDERAL DE 1988}

\subsection{Introdução}

Após analisar conceitos basilares à presente pesquisa, como a constituição dirigente e a constituição econômica, as origens históricas do debate econômico sobre o desenvolvimento e sobre diversas opiniões sobre o entendimento do artigo 219, é possível que se passe efetivamente a um estudo aprofundado sobre o texto do dispositivo que trata da defesa do mercado interno nacional.

Dentro das teorias desenvolvimentistas furtadiana e da CEPAL, o mercado interno tem papel determinante para a concretização do desenvolvimento econômico de um determinado país. Mais do que isso, é por meio da sedimentação deste importante componente econômico que, para Furtado, Prebisch e toda a escola estruturalista latinoamericana, que os países subdesenvolvidos poderão superar suas históricas deficiências em relação aos países centrais, subvertendo a lógica centro-periferia e concretizando assim o tão desejado desenvolvimento econômico-social.

Se a discussão sobre a internalização dos centros de decisão econômica já não é nova na economia política, o mesmo não se pode falar no direito econômico. Foram poucos os pesquisadores do direito que se debruçaram sobre o tema. Muitas das análises sobre o conceito de mercado interno partem de um conceito dado, onde pouca ou nenhuma reflexão é garantida a este conceito. Talvez por ser um termo com a origem ligada às ciências econômicas, os estudiosos das ciências jurídicas tenham emprestado a ela poucas linhas de suas pesquisas.

A escassez de reflexões conceituais não recai apenas sobre a ideia de mercado interno. Se o termo tem origem em ciência externa às ciências jurídicas, o mesmo não se pode falar sobre o conceito de patrimônio nacional. Com pouquíssimas referências sobre o assunto, o termo é historicamente confundido como mero sinônimo do conceito de patrimônio público. Duguit já apontava que, em 1790, a própria legislação francesa tratava de igualar 
este conceito. Porém, além do fato do próprio texto constitucional se referir de formas diferentes entre a noção de patrimônio público e patrimônio nacional, há de se observar que a transposição de termos nestes casos é impossível. Assemelhar ambos em um único conceito seria, por exemplo, dar à Floresta Amazônica e ao Pantanal o status de patrimônio público, o que ensejaria na desapropriação forçada de todas as terras ali localizadas. Isso porque, o parágrafo $4^{\circ}$ do artigo 225 da Constituição de 1988 avoca como patrimônio da nação ambos os biomas.

Por tudo isso, para que se dê conta do que o legislador efetivamente quis dizer ao inscrever o mercado interno como sendo parte integrante do patrimônio nacional, será necessário buscar tanto nas ciências jurídicas, como na economia e na história, os conceitos que darão o amparo necessário à tarefa a ser empreendida neste capítulo.

É importante ressaltar aqui que outros conceitos já apresentados - como, por exemplo, a noção de desenvolvimento econômico - serão novamente trazidos a baila, para que se possa ter uma dimensão mais apurada do sentido que o legislador talvez tenha dado ao artigo em comento.

Ainda, lembramos que esta dissertação não tem a pretensão de garantir um sentido único ao artigo 219. O que pretendemos é apenas traçar um esboço interpretativo ao dispositivo analisado que guarde coerência tanto com o texto constitucional como um todo, como com a constituição econômica formal do Brasil e seu projeto de desenvolvimento.

Antes que seja possível traçar algumas linhas sobre a presente relação, será necessário apontar os conceitos citados aqui. Assim, iniciaremos o presente capítulo com o estudo do conceito de mercado interno.

\subsection{Definição de Mercado Interno}

O conceito de mercado interno, a primeira vista, parece estar pacificado dentro do direito brasileiro. Em verdade, os poucos escritos que tratam sobre o tema costumam garantir o mercado interno como algo dado, sem muitos questionamentos. 
Em que pese o conceito não ser, mesmo nas ciências econômicas - de onde foi emprestado - um termo polissêmico, é possível que se veja, nas poucas vezes em que o termo é referenciado na doutrina nacional, certa vagueza de parte dos textos jurídicos que dele se valem. Porém, tal fato causa um problema objetivo. Nesta pesquisa, conceituar o termo mercado interno é imperioso para que se possa esboçar a significância do dispositivo constitucional aqui estudado. Mas não é só isso.

Apreender o que significa o mercado interno à economia política é mais que mera curiosidade científica. O correto entendimento do que efetivamente o termo exprime em termos jurídico-econômicos é importante para a compreensão do que ele significa para o próprio desenvolvimento das economias capitalistas.

Porém, o termo em análise advém de outro conceito, muito mais difuso e de caro entendimento até para a economia. O termo mercado, ao longo da história, ganhou inúmeras definições, de forma que dar a esta palavra uma ideia de conceito unívoco é, se não ingenuidade, ato que depõe contra a própria história da ciência econômica.

De toda forma, dado que é impraticável compreender o significado do termo mercado interno sem que haja alguma definição sobre o que o conceito de mercado pode exprimir, para fins desta dissertação nos valeremos de uma opção conceitual que guarda mais proximidade com a hipótese depreendida.

Desta maneira, a definição do termo referenciado junto ao artigo 219 da Constituição Brasileira parte de uma ideia mais ampla, que é basilar para a compreensão do próprio capitalismo. Não por outro motivo, talvez a melhor captura do que o conceito de mercado exprime tenha sido feita pela historiografia econômica. Mais ainda, é possivelmente a escola crítica da economia política quem mais tenha se dedicado ao estudo deste conceito e suas implicações.

Para esta tarefa, nos valeremos de autores que estão ligados à filosofia crítica, cuja maior expressão é, como se sabe, Karl Marx. Além, autores que, em que pese não terem relação 
direta com Marx ou o marxismo, como Karl Polanyi, serão aqui utilizados. Segue-se então para a definição de mercado.

\subsubsection{Algumas definições de mercado}

O mercado não é uma invenção do capitalismo. Na verdade, ao buscar a etimologia do termo, rapidamente se conclui que o conceito de mercado enquanto uma instituição com leis próprias, onde indivíduos buscam maximizar seu bem estar, é bastante nova quando se olha para a história da humanidade. De fato, o mercado ao longo da evolução das sociedades, parece ter sido organizado de outra forma , que não necessariamente ligada ao lucro.

Karl Polanyi recorda que a base do mercado é a troca (permuta ${ }^{237}$. Apesar de simplista e até rasa em primeira vista, esta afirmação traz a ideia de que o mercado enquanto ambiente de trocas que visem o lucro de um dos partícipes não é uma condição apriorística. Assim, surge o questionamento se à ideia de mercado está sempre incutida a necessidade de lucro financeiro.

Antes de responder esta pergunta, cabe aqui uma pequena referência. Conforme lembra João Antônio de Paula, a $5^{a}$ edição do Dicionário de Moraes Silva, de 1844, a palavra mercado é registrada unicamente como sendo uma feira, praça ou local onde se vende víveres. $^{238}$ A importância do fato reside em lembrar que, até pouco menos de 170 anos atrás, o termo mercado é referenciado unicamente em seu sentido espacial, enquanto local de trocas.

Independentemente do uso da palavra estar referenciado em seu conceito espacial por boa parte da história, inclusive da língua portuguesa, restaria a defesa de que o termo estaria sempre ligado à permuta baseada no lucro.

\footnotetext{
${ }^{237}$ POLANYI, Karl. A grande transformação: as origens da nossa época, 3a edição. Rio de Janeiro: Ed. Campus, 1980, p. 75.

${ }^{238}$ PAULA. João Antônio de. O mercado e o mercado interno no Brasil: conceito e história. História Econômica \& História de Empresas, 2002, vol. 1, p. 8.
} 
Retomando assim a pergunta anterior, onde questionamos se o lucro é o elemento motriz das permutas no mercado, lembram Polanyi e Braudel que não. Karl Polanyi, se preocupando em confirmar que a economia é um subsistema da vida social, lembra que nas antigas civilizações polinésias subsistia o $u t u$, uma espécie de troca recíproca onde o doador simplesmente largaria o objeto ao chão e o interessado, ou um dos seus seguidores, poderia fingir apanhar o dito objeto acidentalmente. $\mathrm{O}$ ato, razoavelmente complexo, foge bastante à lógica da barganha, condição precípua para a aferição de lucro ou diminuição dos custos da transação. ${ }^{239}$

Polanyi lança mão deste exemplo para pontuar que "talvez seja audacioso afirmar que os mercados locais se desenvolveram a partir de atos individuais de permuta." 240

Ao que parece, é o mesmo caminho que trilhará Fernand Braudel, que cita o próprio Polanyi para ir além e lembrar que "a noção de 'mercado auto-regulador' que nos é proposta, é uma criação da mente." 241 Como lembra o historiador francês, ao longo da história da humanidade, reciprocidade, redistribuição e também a troca à título oneroso são realidades que permearam o mercado desde sempre. ${ }^{242}$ Citando Malinowski, aponta que até a década de 1970, no arquipélago Trobriand, sudeste da Nova Guiné inglesa, subsistiam trocas cerimoniais. $^{243}$

Este é o ponto a ser salientado. O mercado é uma criação social, desenvolvido de várias formas nas várias culturas. Porém, é sempre bom lembrar, que o mercado como instituição auto-regulada, dotada de leis próprias imutáveis, além de cientificamente pretensioso, é historicamente errado. Mais ainda, este fato não é uma realidade polinésia ou maia. Como lembra de Paula, os romanos e várias sociedades feudais admitiam a troca baseada em fatores não econômicos. ${ }^{244}$ Não só, como aponta Braudel, o mercado nas terras ermas da Cabília e até mesmo no sertão do Bahia, funcionam muitas vezes em lógica que remonta uma economia arcaizante. ${ }^{245}$

\footnotetext{
${ }^{239}$ POLANYI, Karl. Op. cit., p. 75 e 76.

240 Idem ibidem, p. 76.

${ }^{241}$ BRAUDEL, Fernand. Civilização material, economia e capitalismo, séculos XV-XVIII, vol. 2 - Os jogos das trocas. São Paulo: Martins Fontes, 1998, p. 195

242 Idem ibidem, p. 195.

243 Ibidem, p. 193.

244 PAULA, José Antônio de. Mercado e o mercado interno no Brasil.Op. Cit., passim.

245 BRAUDEL, Fernand. Civilização material, economia e capitalismo, séculos XV-XVIII, vol. 2, Op. cit., p. 193.
} 
Por fim, é que o que de mais importante se apreende aqui é que o "mercado a título oneroso", apontado por Braudel, ${ }^{246}$ sempre esteve presente na vida das mais diversas culturas. É uma face da relação de trocas, fazê-la sob o signo que do convencionou-se em econômico. Não que a troca baseada na reciprocidade, redistribuição ou mesmo sob o signo religioso não seja econômica. Elas só não pertencem à nossa forma organizativa sócio-econômica, a qual se convencionou chamar de capitalismo.

Fernand Braudel lembra ainda que não é só a face onerosa das relações de trocas que mantém sua dimensão fora de um único contexto histórico-social. Mesmo a flutuação de preços de acordo com a oferta e demanda está colocada desde que subsistem as trocas. A ideia do historiador francês é diferenciar suas teses da de Polanyi, que atribui à economia de mercado a evolução econômica ocidental do século XIX. Lembra que na antiguidade, na Europa do século XII e até nos minúsculos burgos Faucigny, da Sabóia do século XVIII, havia a flutuação de preço de bens, de acordo com fatores externos, relações de oferta e demanda, por estarem tais mercados ligados às rotas comerciais ou não. ${ }^{247}$

Feita esta pequena introdução, resta agora conceituar o mercado dentro da economia capitalista. Aliás, de pronto, é importante lembrar que se o capitalismo de hoje não é o mesmo de ontem, o mercado também não. Entre o capitalismo industrial do século XIX e o capitalismo financista do século XXI, existem muitas diferenças. Não é estranho, portanto, que o espaço virtual organizativo das trocas dentro dessas diferentes formas do sistema também tenha mudado. Ao longo da história, o conceito de mercado se modificou e se especializou. Quão mais complexa se tornaram as relações econômicas entre seus agentes, mais complexos se tornariam os ambientes de troca. Se há uma verdade da conceituação evolutiva dos economistas liberais é que a complexidade do mercado variou conforme a complexidade do sistema. De um mero espaço físico de trocas, mais ou menos complexas, o mercado se tornou algo desconexo com a realidade, que suporta inúmeras variações de trocas pecuniárias entre seus partícipes.

Entretanto, o que importará aqui é demonstrar o que é o mercado através de suas características. A questão é que se o mercado como conhecemos segue a fórmula

\footnotetext{
${ }^{246}$ Idem ibidem, p. 195.

${ }^{247}$ Ibidem, p. 195.
} 
inaugurada por Adam Smith que, como lembrada por Ellen Wood, teria se formado pela propensão natural dos indivíduos para comerciar, permutar e trocar, e que se voltam racionalmente para seus próprios interesses ${ }^{248}$, haveria então alguma dificuldade em conceituá-lo apenas como locus de trocas econômicas onde os agentes buscam maximizar o seu bem estar racionalizando seus custos, obedecendo basicamente à regra da variação de preços de acordo com a oferta e a demanda?

Como lembra José Antônio de Paula, os itens faltantes, que diferenciarão o mercado do sistema capitalista dos mercados nos sistemas antecessores e concorrentes, estão nas contribuições de Karl Marx..

A primeira grande contribuição de Marx está na demonstração de que a venda da força de trabalho de um ser humano a outro é a maior diferenciação do mercado em outros modelos produtivos. A recompensa pecuniária àquele que não detém os meios de produção da vida social, é a força motriz da organização do sistema capitalista. Esta diferenciação não é específica do capitalismo, como faz questão de lembrar. É, antes de qualquer outra coisa, categorial, dado que o ser humano vende sua força de trabalho desde as primeiras organizações sociais. A diferença é que enquanto método marginal de produção da vida social em outros modos de produção, no capitalismo e em especial no capitalismo industrial, dada a concentração dos meios de produção na mão de pouquíssimos seres humanos, a venda da força de trabalho torna-se a condição existencial deste modo de produção.

A segunda contribuição marxiana para a compreensão do capitalismo e de sua definição de mercado é decorrente da primeira. Dado que para amealhar seu sustento o ser humano intermedeia sua força de trabalho no mercado, este atravessador torna-se então o grande mediador das relações sociais. No capitalismo, o mercado não é apenas uma parte da vida social. Neste modo de produção, a quantificação de todas as relações em dinheiro inclusive reparações a danos morais - torna o mercado o mediador de todas as relações humanas. Tudo no capitalismo é, ainda que a posteriori, quantificável em dinheiro.

${ }^{248}$ WOOD, Ellen Meiksins. A origem do capitalismo. Rio de Janeiro: Jorge Zahar Editor, 2001, p. 22. 
Por isso, ao conceituar o mercado deve-se sempre ter em conta que a permuta está presente desde os primórdios das civilizações humanas. Já o mercado como locus virtual de trocas onde um dos partícipes necessariamente visa o lucro e o outro visa maximizar seu bem estar, que intermedeia todas as relações sociais, parece ser uma construção do capitalismo.

Talvez a maior importância desta consideração seja ressaltar a noção de que este mercado - que é o conceito que se valerá aqui - é uma construção histórico-social, organizada dentro de um modo de produção específico das sociedades humanas.

Assim, uma vez feitas estas breves considerações, avança-se em busca de uma definição para o conceito de mercado interno.

\subsubsection{Definição geográfica e histórico-econômica do mercado interno}

Em seu $O$ desenvolvimento do capitalismo na Rússia, Lênin é enfático ao afirmar que "o mercado interno aparece quando aparece a economia mercantil." ${ }^{249}$ Para o líder russo, o grau de desenvolvimento do mercado interno de um país dependerá do grau de desenvolvimento do capitalismo daquela nação, sendo que será o grau de fragmentação da divisão social do trabalho que determinará o nível do desenvolvimento daquele mercado.

De fato, o surgimento do mercado interno parece estar ligado ao surgimento e desenvolvimento do capitalismo, mas não só. Na verdade, como lembra de Paula, o surgimento e desenvolvimento do capitalismo não se deu de forma linear em todos os países. ${ }^{250}$ A popularização do estudo do desenvolvimento das economias através de Marx terminou por passar a ideia, ao menos aos marxistas presos sob o entendimento stalinista de seu pensamento, que o modelo de desenvolvimento do capitalismo seria o modelo inglês.

De qualquer forma, o desenvolvimento do capitalismo inglês, ainda que replicado em outros países, parece ser a melhor demonstração de que o mercado interno é fruto do desenvolvimento do capitalismo em determinada nação. Mesmo aos economistas não tão

\footnotetext{
${ }^{249}$ LENIN, Vladmir Ilich. O desenvolvimento do capitalismo na Rússia. O processo de formação do mercado interno para a grande indústria. São Paulo: Abril Cultural, 1982, p.33.

${ }^{250}$ PAULA, José Antônio de, Op. Cit., p. 14 e 15
} 
ligados à escola crítica, como Paulo Sandroni, admite-se que o desenvolvimento do mercado - e por consequência do mercado interno - está intimamente ligado à especialização e divisão do trabalho ${ }^{251}$.

A origem deste pensamento está em Marx. Para ele, o surgimento do mercado interno é condição para o nascimento do sistema capitalista. Sua formação estará naquilo que convencionou chamar de acumulação primitiva, que seria "o processo histórico de separação entre produtor e meio de produção." 252

Ou seja: para Marx, a formação do mercado interno está ligada à criação da classe trabalhadora e do mercado de terras. Isso porque o processo de criação do mercado de trabalho foi antecedido pelo processo de expulsão do campesinato de suas terras, criando as condições para que o mercado de terras se tornasse algo de vulto.

É importante notar que o mercado interno nasce em substituição à produção local. A autosuficiência do campesino em produzir seus víveres e trocá-lo localmente vai desaparecendo conforme o capitalismo se desenvolve. É que a expropriação de camponeses que antes eram economicamente autônomos e sua separação dos meios de produção ocorrerá concomitantemente à destruição do que chamou de "indústria subsidiária rural”. Será através da destruição desta indústria que será propiciado ao mercado interno de um país a extensão e a sólida coesão de que o modo de produção capitalista necessita ${ }^{253}$.

Assim, é possível perceber que o mercado interno, diferentemente do modelo de circulação de mercadorias pré-capitalista, está atrelado não à circulação de mercadorias em um sistema simples de troca. Para o filósofo alemão, o mercado interno é o espaço nacional de circulação do capital. É o ambiente que dá condições para que o capital circule, mantendo o modelo de venda da força de trabalho da massa proletária para sua subsistência.

Outro ponto a ser salientado dentro da concepção marxista de formação do mercado interno diz respeito aos seus componentes. Para Marx, o mercado interno é constituído a

\footnotetext{
${ }^{251}$ SANDRONI. Paulo. Dicionário de economia do século XXI, Rio de Janeiro: Record, 2005, p. 529.

${ }^{252}$ MARX. Karl. O capital: crítica da economia política, Vol. I, Tomo II. São Paulo: Nova Cultural, 1985, p.262.

253 Idem ibidem, p. 283 e 284
} 
partir da formação do mercado de trabalho e do mercado de terras de um país. Como visto, tais componentes formadores são decorrência do próprio processo de industrialização, que no caso da Inglaterra, se dará no mesmo processo de formação do capitalismo. Assim, será através do que chamou de processo de acumulação primitiva do capital que se lançarão as bases para a constituição do mercado interno de um país.

Entretanto, se Marx parece dar boas pistas sobre a origem e significado do termo, , encontrar economistas que tenham definido o termo mercado interno fora do marxismo não é tarefa das mais fáceis. Talvez pelo excesso de uso comum, encontrar nas ciências econômicas definições para o termo não é ato simples.

Alguns outros economistas não filiados à teoria crítica também podem contribuir para a definição do termo. Ainda que não tenham se preocupado tanto com as origens históricas e razões de sua formação, as formulações parecem ser próximas do que Marx apontou.

Sandroni ira conceituar o mercado nacional como uma variação de alcance do mercado. Apontando ser o mercado "um grupo de compradores e vendedores que estão em contato suficientemente próximo para que as trocas entre eles afetem as condições de compra e venda dos demais. ${ }^{254}$ Este conceito parece corroborar com o citado por Échaudemaison, como sendo o "lugar de encontro entre uma oferta e uma demanda que leva à formação de um preço." 255

Assim, o mercado nacional - que em termos gerais pode ser considerado como um sinônimo para o conceito de mercado interno - será uma definição de alcance do referido mercado. Sandroni explica ainda que os fatores que determinam o alcance de um mercado estão a escala de produção, as características da mercadoria, a amplitude da demanda, o grau de organização do comércio e o estágio de desenvolvimento econômico e social.

A definição aqui aludida indica a aplicação do termo em um único segmento de uma economia. Se Marx procurou dar um sentido histórico-econômico ao termo, Sandroni trata de dar à terminologia mercado apenas uma variante espacial a uma determinada troca.

\footnotetext{
254 Idem ibidem, p. 528.

255 ÉCHAUDEMAISON, Claude-Danièle. Dictionaire dÉconomie et de Sciences Sociales. Paris: Édition Nathan, 2001, p.304.
} 
Muito possivelmente, esta conceituação, largamente aceita entre os economistas brasileiros, esteja mais preocupada em descrever as características de um determinado segmento de mercado como, por exemplo, o mercado financeiro, do que necessariamente buscar definir o conceito aqui estudado.

Porém, apesar de não dar ao conceito a dimensão crítica de circulação do capital, o termo guarda relação com o prescrito por Marx, dado que trata do mesmo espaço físico, qual seja, a nação.

Por isso, tudo indica que o conceito de mercado interno parece desaguar no espaço nacional de circulação de capital. Em linhas mais gerais, parece ser o mercado produtor e consumidor de uma determinada nação.

É o sentido que parece adotar ao menos uma parte da doutrina jurídico-econômica. Dentre os brasileiros, há a definição corrente de mercado interno como sendo "a relação entre oferta e procura numa determinada base territorial, normalmente igual a um país" ${ }^{\text {256 }}$, da qual compartilha Ricardo Camargo ${ }^{257}$. Se esta definição não problematiza nem as origens, nem as implicações da definição de mercado interno, ela guarda relação direta com o prescrito por Marx e Lênin.

Enquanto a concepção marxiana de mercado interno dá ao termo sua dimensão históricoeconômica, o conceito econômico-geográfico parece dar a completude necessária para que seja possível apreender o mercado interno não apenas como um espaço de circulação de capital historicamente constituído dentro do processo de formação do sistema capitalista europeu. Além disso, o mercado interno é, em termos estritamente econômicos, o conjunto de relações de oferta e procura em uma determinada base territorial, que geralmente é equivalente a um país.

Uma vez analisado o termo mercado interno, seguimos então para a tentativa de delimitação do que seria o conceito de patrimônio nacional. Se no caso do mercado interno

\footnotetext{
${ }^{256}$ FUNDAÇÃO BRASILEIRA DE DIREITO ECONÔMICO. Novo dicionário de Direito Econômico. Porto Alegre: Sergio Antonio Fabris, 2010, p. 320 e 321.

${ }^{257}$ CAMARGO. Ricardo Antonio Lucas. O mercado interno, o patrimônio público e o Artigo 219 da Constituição Brasileira de 1988: bases para sua interpretação. In: Direito Econômico e Direito Administrativo: o Estado e o poder econômico. Porto Alegre: Sergio Antonio Fabris Editor, 2006, p. 86.
} 
parece não recaírem muitas dúvidas, o termo patrimônio nacional passa longe de ser tratado pelas ciências jurídicas como unívoco. A constante confusão entre patrimônio público e patrimônio nacional, como se verá, dificulta uma conceituação objetiva para o que seria o patrimônio de uma nação.

\subsection{Patrimônio Nacional}

Seguindo a trilha de definições que corroborem para a construção de um esforço interpretativo do artigo 219 da Constituição de 1988, caminha-se então para buscar o entendimento das ciências jurídicas sobre o que seria o termo patrimônio nacional.

Como dito, o termo em análise foi - e é - constantemente confundido com outro importante conceito do Direito Público, o patrimônio público. Em que pese a evolução histórica dos conceitos ter comportado várias acepções correlatas, tomar um conceito pelo outro, neste caso, inviabilizaria a pesquisa aqui proposta.

Em primeiro lugar, tratar o conceito de patrimônio nacional como público, causa um problema de exegese constitucional. A Constituição Brasileira em vigor trata com frequência de um termo e de outro, dando, em cada caso, sentido distintos a eles. A impossibilidade de sobreposição de termos como sinônimos no processo de interpretação de uma constituição faz com que obrigatoriamente se procure diferenciar um e outro.

Ainda, como veremos adiante, durante décadas a doutrina administrativista buscou diferenciar os bens que efetivamente seriam propriedade do Estado daqueles que, apesar de pertencerem a particulares, estariam sob a tutela potencial do Estado. O poder de polícia enquanto limitador do direito de propriedade, legitimado pela soberania do Estado, dá a este o direito de, dentro dos limites e imposições legais, dar destinação diversa da vontade do proprietário, em virtude da manutenção do interesse da maioria.

Assim, nas próximas linhas, esta pesquisa procurará diferenciar o que é patrimônio estatal e o que seria o patrimônio nacional. 


\subsubsection{Conceito de patrimônio e de patrimônio privado}

Dentre os termos a serem aqui definidos, poucos possuem tantos estudos quanto o conceito de patrimônio.

Clovis Bevilaqua irá conceituar o patrimônio com o que apontou ser "a maioria dos autores". Para ele, o patrimônio seria uma universalidade de direito, ou seja, uma universalidade abstrata que é distinta dos elementos que a compõem. ${ }^{258}$ Para o autor, constituem o conceito de patrimônio a posse, os direitos reais, os intelectuais, os obrigacionais, as relações econômicas do direito de família e ações oriundas destes direitos. $^{259}$ Em suma, como aponta Caio Mario da Silva Pereira, patrimônio seria o “complexo das relações jurídicas de uma pessoa, apreciáveis economicamente." 260

Porém, conforme demonstra o próprio autor, apesar de estar muito distante de um consenso, tal conceituação tem méritos. Talvez, o maior deles seja o de não incorrer em exagerada abstração ao tempo que abrange todo o conjunto de direitos. ${ }^{261}$ A importância da conceituação do termo como conjunto de direitos reside no fato, segundo Caio Mario, mesmo que de início uma relação comercial não permita que se saiba quais serão seus efeitos, sabe-se que haverá reflexo econômico, que incidirá no patrimônio dos envolvidos.

Independentemente de se saber qual foi o primeiro conceito dado ao termo, é certo que o que possivelmente pavimentou a discussão sobre patrimônio foi o direito romano. Max Kaser aponta, ao conceituar a res romana, que esta admitiu basicamente três conceitos: a ideia generalista, de tudo aquilo que possa ser objeto de um direito privado; a noção de tudo aquilo que processualmente possa ser objeto de direito (como em algumas relações, os filhos), e a res enquanto patrimonium, que seria o conjunto de coisas com valor monetário. $^{262}$

\footnotetext{
${ }^{258}$ BEVILAQUA, Clovis. Theoria Geral do Direito Civil, 2ª edição. Rio de Janeiro: Livraria Francisco Alves, 1929, p. 211.

259 Idem ibidem, p. 213 e 214.

${ }^{260}$ PEREIRA. Caio Mario da Silva. Instituições de Direito Civil, vol I, 22a edição. Rio de Janeiro: Editora Forense, 2007, p. 391.

${ }^{261}$ Idem ibidem, p. 391.

${ }^{262}$ KASER, Max. Direito Privado Romano. Lisboa: Fundação CalousteGulbenkian, 1999, p. 121.
} 
Esta conceituação parece ter sido, ainda que em parte, carregada ao longo da história. Charles Aubry e Frederic C. Rau irão traduzir o conceito de patrimônio como sendo "l'ensemble des biens d'une persone."263 Seguem os autores apontando o que possivelmente fora o gérmen da concepção universalista sobre o patrimônio. Mostram, ainda no século XIX, que o patrimônio é uma universalidade de direito.

A ideia de universalidade de direito tem relação com o conceito apresentado por Kaser. $\mathrm{Na}$ verdade, a ideia de patrimônio se divide desde os romanos em duas correntes: o patrimônio como universalidade de fato e como universalidade de direito.

O patrimônio como universalidade de fato constitui apenas os bens, sendo sempre presumidos apenas os bens, não se incorporando as obrigações. Ainda, neste caso, a universalidade é dada por um propósito específico, o que faz com que os bens que compõem tal universalidade possam ser, a qualquer tempo, separados. Ainda, além de consistirem quase sempre bens de natureza econômica, "a universalidade de fato refere-se a um conjunto de bens autônomos e distintos entre si, corpóreos ou incorpóreos, que são considerados menos em sua singularidade material que em sua valoração pecuniária." 264

Do outro lado, para Aubry e Rau, o patrimônio constitui uma universalidade de direito porque por estarem sob a tutela de uma única pessoa, constituem o todo jurídico. ${ }^{265}$ Ainda, como lembra Bercovici, em que pese o conjunto de bens, dentro da universalidade de direito, estar sujeito ao seu desmembramento e trato isolado, este conceito de patrimônio termina também por abarcar os ativos e passivos de uma determinada pessoa, uma vez que comporta não apenas os direitos, mas também as obrigações de cada um. ${ }^{266}$

Vê-se então que a colocação mais simplista do patrimônio enquanto conjunto de direitos parece não ser uníssona na doutrina. Ao que foi demonstrado, o conceito mais completo de patrimônio parece ser mais próximo ao conceito de universalidade de direitos, sendo um entendimento ampliado do conceito passado por Caio Mário da Silva Pereira.

\footnotetext{
${ }^{263}$ AUBRY, Charles; RAU, Frederic Charles.Cours de Droit Civil Français D’Aprés la Méthode de Zachariae, 5a edição. Paris: Marchal et Billard, 1897, p.3

${ }^{264}$ BERCOVICI, Gilberto. Ciência e inovação sob a CONSTITUIÇÃO DE 1988. Revista dos Tribunais. São Paulo: Editora Revista dos Tribunais, vol. 101, no 916, p. 282, fev. 2012

${ }^{265}$ AUBRY, Charles; RAU, Frederic Charles, op. Cit., p.3.

${ }^{266}$ BERCOVICI, Gilberto. Ciência e inovação sob a constituição de 1988, cit. p. 283.
} 
Toda a doutrina aqui abordada é de origem civilista, e, portanto, privada. Dentro da esfera particular, em que pese os imensos debates, o conceito de patrimônio, somado ou não a ele as obrigações de um determinado indivíduo, está sempre atrelado à mensuração pecuniária de direitos. Em todos os casos, vimos que o trato do conceito de patrimônio parte da premissa de sua mensuração econômica.

Tal construção tem origem privatista. Até porque as relações patrimoniais, como conceituadas mais cedo, pressupõem que sejam oriundas de relações entre pessoas. Ou seja, originariamente, a ideia de patrimônio está diretamente imbricada à personalidade jurídica. Não há, sob a égide civilista um patrimônio que não tenha um sujeito de direito.

Mesmo hodiernamente, viu-sevimos que a caracterização do patrimônio, dentro do Direito Civil é dada a uma pessoa específica. Mais do que isso, não apenas a uma pessoa de direito privado.

Como será demonstrada adiante, esta construção se mantém, em boa medida, até os dias atuais. Mesmo em nosso país, a caracterização dos bens públicos está inscrita no artigo 99 do Código Civil Brasileiro de 2002.

São muitas as consequências desta inserção, que é clássica do Direito Civil de tradição romanista. Ao que interessa aqui, ressaltamos duas: a primeira é o tratamento simplista que o direito civil termina por dar à discussão de patrimônio público. A segunda é sobre a confusão de conceitos, uma vez que o simplismo doutrinário e legislativo termina por dificultar a demonstração do que seria, por exemplo, o conceito de patrimônio nacional.

Assim, a absorção deste conceito dentro da lógica publicista já será limitada em si. Ao analisarmos o conceito de patrimônio público, será visto que a simples transmissão patrimônio-pessoa é insuficiente para tratar, por exemplo, de questões como os bens sujeitos às servidões administrativas, que não perdem sua titularidade - ligada a um ente privado - porém, estão sujeitos a tratamento diferenciado, podendo o Estado forçar o seu uso à comunidade, de forma alheia à vontade de seu proprietário. 
Mais do que isso, o conceito de patrimônio sob uma ótica privatista torna-se inaplicável quando transposto à ideia de patrimônio nacional, onde há uma propriedade específica, mas sob uma potencialidade de domínio do Estado, para que se promova o bem comum.

É o que passamos a estudar agora.

\subsubsection{Patrimônio público}

Uma vez expostos alguns conceitos de patrimônio privado, passa-se então a diferenciar aqui o que seria o patrimônio público. Tal discussão é bastante antiga e remonta, como aponta Rafel Bielsa, ao próprio direito romano. ${ }^{267}$ Ao longo da história, inúmeras correntes de estudiosos do direito público se debruçaram sobre o tema. Via de regra, procuraram diferenciar os conceitos de domínio público, patrimônio público e de bens públicos. Ainda, em alguns casos, como o próprio Bielsa, trataram ainda de inserir conceitos como o domínio do Estado.

De fato, subsistem inúmeras correntes, tanto de direito administrativo como de direito público em geral, que debateram o tema. Em cada nação, ao longo de suas histórias, são várias as proposições sobre cada termo aqui citado.

Entretanto, se as correntes publicistas se encarregaram de traçar inúmeras diferenças entre cada conceito, não é impossível indicar os pontos de ligação entre elas. Assim, trataremos aqui não apenas de diferenciar cada uma, mas ao mesmo tempo, caracterizar o que há de comum entre elas.

Mais do que isso, a presente dissertação trabalha com a ideia de que o conceito de patrimônio público se difere da ideia de patrimônio nacional. Sabemos, porém, que ao longo da história, ambos os termos continham o mesmo sentido. Conforme aponta Duguit, a lei (decreto) de 22 de novembro $-1^{\circ}$ de dezembro de 1790 (Código Administrativo Francês pós-revolução) empregava o mesmo sentido ao conceito de domínio público e

\footnotetext{
${ }^{267}$ Ao buscar definir o que seria o conceito de domínio público, Bielsa se vale da distinção romanista entre domínio público e domínio do Estado. Lembra o autor argentino que já em Roma, apontava-se como domínio público aqueles bens fora do comércio. In BIELSA, Rafael. Derecho Administrativo. Buenos Aires: La Ley, 6ạ edição, 1964, p. 456.
} 
domínio nacional ${ }^{268}$. Como se dirá à frente, será com o desenvolvimento do direito ambiental e do direito urbanístico contemporâneo que a diferenciação entre o que é "público" e o que é "nacional” será aclarada.

Ainda, há de se lembrar que a legislação brasileira possui conceito fechado sobre o que seria o patrimônio público. Conforme aponta o parágrafo $1^{\circ}$ do artigo $1^{\circ}$ da Lei $4.717 / 65$, que regula a ação popular, o patrimônio público seria "os bens e direitos de valor econômico, artístico, estético, histórico ou turístico". Por hora, cumpre apenas o registro, sendo que ao final deste tópico, retomaremos o conceito para confrontá-lo com a doutrina.

Entre nós, ressalta-se aqui a noção passada por Hely Lopes Meirelles, que define o patrimônio público como sendo "formado por bens de toda natureza e espécie que tenham interesse para a Administração e para a comunidade administrada” 269 . O termo, que guarda alguma relação com o disposto na lei da ação popular, também parece esclarecer pouco o conceito abordado, se fazendo necessário um melhor exame da matéria.

Iniciando agora a discussão doutrinária sobre o tema, há de se colocar em primeiro lugar o posicionamento de León Duguit, a quem, como observou Bercovici, tratou de diferenciar a noção de patrimônio público de patrimônio privado ${ }^{270}$.

Primeiramente, Duguit inicia a discussão sobre patrimônio público, pela definição tradicional de patrimônio. O constitucionalista de Bordeaux sintetiza o conceito generalista de patrimônio da seguinte maneira:

"La conception civilistique et classique du patrimoine apparît ainsi très nettement. Elle se rattache directement à celle de personnalité juridique. Le patrimoine est un ensemble de droits d'orde pécuniaire et de charges ou, comme disent certains civilistes, um ensemble de droits actifs et passifis,"271.

\footnotetext{
${ }^{268}$ DUGUIT, Léon. Traté du Droit Constitutionnel, 3a edição, vol. III. Paris : Ancienne Librarie Fontemoing \& Cie, 1930, p.345.

${ }^{269}$ MEIRELLES, Hely Lopes. Direito Administrativo Brasileiro, 16a edição. São Paulo: Revista dos Tribunais, 1991, p. 422.

${ }^{270}$ BERCOVICl, Gilberto. Ciência e inovação sob a Constituição DE 1988. Revista dos Tribunais. São Paulo: Editora Revista dos Tribunais, vol. C, no 915, p. XXX-XXX, fev. 2012.

${ }^{271}$ DUGUIT, Léon. Traté du Droit Constitutionnel, 3a edição, vol. III. Paris : Ancienne Librarie Fontemoing \& Cie, 1930, p.323.
} 
À primeira impressão, vemos que o conceito generalista de patrimônio dos franceses do início do século XX é, antes de qualquer coisa, civilista. Incutindo ao conceito de patrimônio a noção de uma soma de direitos de ordem pecuniária e de encargos, a noção geral de patrimônio termina por pecar por ser demasiadamente privatista.

Tal fato possivelmente guarda relação com a origem da definição do termo. Como já demonstrara Otto Mayer, a noção de patrimônio é, antes de tudo, ligada ao direito civil ${ }^{272}$. Seja pela doutrina francesa, seja pela alemã, a conceituação do que seria o patrimônio tem seu berço nas escolas civilistas.

Não por menos, Duguit vai tratar de apontar a insuficiência do conceito para a esfera pública.

Seguindo em seu raciocínio o constitucionalista tratará de demonstrar a superação do conceito - que até o início do século XX vigorava - que dizia ser o Estado dotado de duas personalidades: a política e a fiscal. Berthélemy, M. Ducroq, Michoud e mesmo Maurice Hauriou, defendiam inicialmente que o Estado teria este duplo caráter. Tal feita justificaria a extensão de um conceito privatista de patrimônio público, haja vista que ao mesmo tempo em que teria um viés político (Estado-político), diferente da esfera privada, o Estado possuiria também um lado privado. Ao realizar negócios, contratos e afins, teria o ente público um caráter privado (Estado-fisco). Por isso, seria então a noção de patrimônio público, a mesma de patrimônio privado. ${ }^{273274}$

Ao longo do tempo, Hauriou muda sua opinião. Alinhando-se aos preceitos de Jellinek ${ }^{275}$, que sempre defendera a unicidade da personalidade estatal, o administrativista francês irá assumir que o Estado possui uma única personalidade.

\footnotetext{
${ }^{272}$ Com o fito de diferenciar as coisas públicas das demais coisas, lembra que por constituírem res extra commercium, a coisa pública "Goza de uma posición completamente excepcional desde el punto de vista de la aplicación del derecho civil". In MAYER, Otto. Derecho Administrativo Alemán. Tomo III, Buenos Aires : Editorial Depalma, 1951, p. 98

${ }^{273}$ DUGUIT, Léon. Traté du Droit Constitutionnel, cit, p. 326 e ss.

${ }^{274}$ Ainda, para mais informações sobre a discussão deste duplo caráter da personalidade do Estado, vide CAVALCANTI, Themístocles Brandão. Tratado de Direito Administrativo, 3a edição, Tomo III. Rio de Janeiro: Freitas Bastos, 1956, p. 351 e SS.

${ }^{275}$ Sobre Jellineck e a impossibilidade do Estado portar em si duas personalidades, aponta Duguit: "Ces auteurs insistent sur ce point que voir dan l'Estat deux entités, deux personnalités distinctes, l'une
} 
Será então, com a sustentação deste entendimento, que é impossível que a "construção jurídica do Estado" comporte uma dupla personalidade, que Duguit irá lançar as bases de sua teoria sobre o patrimônio público.

Conforme discorre o autor, a questão do patrimônio público deve ser de antemão afastada de qualquer direito subjetivo. A noção de patrimônio privado calcada enquanto direito objetivo deve ser transposta ao patrimônio público. A questão será então o que dará suporte à objetividade deste direito.

Para Duguit, o que diferirá a noção de patrimônio público de patrimônio privado é a afetação do mesmo em relação à personalidade jurídica de seu detentor. Se na esfera privada, a utilização particular do bem sob o domínio de uma pessoa privada será a própria propriedade pela pessoa jurídica privada, no caso do patrimônio público, será a afetação pública que dará ao patrimônio comum o sentido diverso do privado.

Em outras palavras, dado que o Estado deve sempre se compor como sendo interesse da coletividade, o senso de utilidade do bem que compõe o patrimônio público estará afetado sob a égide dos interesses daquela coletividade. Nas palavras do autor:

"Si la théorie juridique du patrimoine peut s'établir sans admettre l'existance d'une personne juridique titulaire de ce patrimoine, quand il s'agit de biens affectés à um but d'utilité individuelle, a fortiori en est-il ainsi quand Il s'agit de biens affectés à um but d'utilité collective et particuliérement affectés au but d'utilité collective que poursuit l'Etat, ou, ce qui est la même chose, de biens affectés aux buts des services publics étatiques. ${ }^{, 276}$

Desta forma, conforme já apontara Gilberto Bercovici, Duguit guia sua tese sobre patrimônio público sob a lógica da afetação. Conforme o autor,

"Para o autor, a noção civilista bipartite de patrimônio vincula-se diretamente ao conceito de personalidade jurídica, que, à parte de sua aplicação problemática no próprio direito privado, seria inaplicável às coletividades. A noção de patrimônio deveria ser fundada na ideia de afetação, de certa quantidade de riquezas, a uma finalidade. Ou seja, o

politique, l'autre patrimoniale, c'est render impossible toute construction juridique de l'Etat.".in DUGUIT, Léon, op. cit., p. 327

${ }^{276}$ DUGUIT, Léon. Traté du Droit Constitutionnel. Op. Cit., p. 337 
patrimônio do Estado estaria estreitamente vinculado à ideia de finalidade. $^{277,}$

Seguindo na linha de Duguit, vemos que, a priori, o patrimônio público é afetado por um senso de utilidade pública. Assim, o poder público poderá dispor de seu patrimônio da forma que melhor entender, desde que respeitados os fins do Estado, que são, antes de mais tudo, os que garantem o bem estar social.

Neste ponto, cabe ressaltar os apontamentos de Jellinek sobre os fins do Estado. Em primeiro lugar, lembra o autor que é irrefutável a ideia de que a vida do Estado é "una serie ininterrumpida de acciones humanas, y como toda acciones necesariamente determinada por un motivo, toda acción es a su vez determinada por un fin." ${ }^{278}$ Seguindo nesta discussão, o autor lembra que estipular um fim único e ahistórico ao Estado é impossível, dado que todas as instituições humanas deve ser compreendidas "como viviendo en um fluir constante" $" 279$. Porém, discorre que é através de instituições como o Estado que os indivíduos realizam seus fins particulares, pessoais. Desta forma, como regra geral aponta o autor que, se é impossível discorrer um único fim comum à ideia de Estado, é possível apontar em determinado momento histórico, quais seriam as concepções particulares daquele tempo sobre os fins de institutos, como o Estado.

Assim, visto que o conteúdo concreto da atividade do Estado só pode ser determinado "enpiricamente, y para un Estado particular, en una situación igualmente concreta de su $v_{i d a}{ }^{280}$, resta apontar neste caso quais seriam os fins do Estado brasileiro. Em nosso caso, parece que tais fins encontram-se no já citado artigo $3^{\circ}$ da Constituição Federal, que apontam como objetivos da República a construção de uma sociedade livre, justa e solidária, a garantia do desenvolvimento nacional, a erradicação da pobreza e a marginalização e a redução das desigualdades sociais e regionais, além da promoção do bem de todos, sem preconceitos de origem, raça, sexo, cor, idade e quaisquer outras formas de discriminação.

\footnotetext{
${ }^{277}$ BERCOVICl, Gilberto. Ciência e inovação na Constituição de 1988, cit. p. 283.

278 JELLINEK, Georg. Teoría General del Estado. Tradução ao espanhol da 2a edição alemã. MontevidéuBuenos Aires: Editorial BdeF, 2005, p. 315.

279 JELLINEK, Georg. Op. cit., p.316.

${ }^{280}$ Idem ibidem, p. 320.
} 
Após esta breve digressão, vê-se que a afetação que Duguit apontou tem relação direta com a finalidade do Estado, que só pode ser dada, conforme aduz Jellinek, em determinado momento histórico e para um ente nacional específico, é possível concluir que no caso brasileiro, o patrimônio público tem sua destinação dada a fins bastante específicos por nosso texto constitucional.

Assim, resta ainda apontar, dado o objeto de estudo deste trabalho, qual seria o conceito de patrimônio público constante à Constituição de 1988.

Em tese de livre-docência apresentada à Faculdade de Direito da Universidade de São Paulo, Floriano de Azevedo Marques Neto tratou de buscar uma definição ao que seria o conceito de patrimônio público dentro da atual Constituição brasileira.

Diferindo o conceito de patrimônio, patrimônio privado e patrimônio público, Marques Neto tratará de expor que, ao analisar tanto o texto constitucional quanto a legislação ordinária é possível caracterizar o conceito patrimônio público como o que se “corresponderia a tudo o quanto economicamente valorável (bens, direitos e receitas) integrantes do domínio dos entes públicos"281.

Tal preceito coaduna não apenas com a legislação infraconstitucional, como a Lei da Ação Popular, já citada aqui. É a própria Constituição que trata do conceito desta forma, como é possível se depreender da leitura dos artigos $5^{\circ}$, LXXIII' $^{282} ; 23^{283} ; 129^{284}$ e do art. 150, VI, alíneas "a" e "c"285.

\footnotetext{
${ }^{281}$ MARQUES Neto, Floriano de Azevedo. O regime jurídico das utilidades públicas: função social e exploração econômica. São Paulo: Tese de Livre Docência, 2008, p. 60.

282 “Art. 50, LXXIII - "qualquer cidadão é parte legítima para propor ação popular que vise a anular ato lesivo ao patrimônio público ou de entidade de que o Estado participe, à moralidade administrativa, ao meio ambiente e ao patrimônio histórico e cultural, ficando o autor, salvo comprovada má-fé, isento de custas judiciais e do ônus da sucumbência." (grifo nosso).

${ }^{283}$ “Art. 23. É competência comum da União, dos Estados, do Distrito Federal e dos Municípios: I - zelar pela guarda da Constituição, das leis e das instituições democráticas e conservar o patrimônio público." (grifo nosso).

284“Art. 129. São funções institucionais do Ministério Público: III - promover o inquérito civil e a ação civil pública, para a proteção do patrimônio público e social, do meio ambiente e de outros interesses difusos e coletivos." (grifo nosso).

${ }^{285}$ “Art. 150. Sem prejuízo de outras garantias asseguradas ao contribuinte, é vedado à União, aos Estados, ao Distrito Federal e aos Municípios:VI - instituir impostos sobre: a)patrimônio, renda ou serviços, uns dos outros;c) patrimônio, renda ou serviços dos partidos políticos, inclusive suas fundações, das entidades
} 
A leitura dos presentes artigos parece mesmo levar às mesmas conclusões de Marques Neto. Até porque, nestes casos é visível que procurou o legislador diferenciar os conceitos de patrimônio, como no caso do inciso LXXIII do artigo $5^{\circ}$, que se vale não apenas do termo patrimônio público, mas também de outras espécies de patrimônio, como o histórico e cultural.

Por tudo isso, há realmente a possibilidade de confluência entre os diversos conceitos de patrimônio público, tanto legislativos quanto doutrinários, a fim de caracterizá-lo enquanto um paralelo público da definição civilista de patrimônio. Por mais que ao Estado seja concedido tratamento diferenciado à proteção de seus bens, o conceito de patrimônio público termina por desembocar na noção de bens, direitos e afins que possuem, direta ou indiretamente, valoração econômica.

Entre as distinções elencadas neste tópico, resta ainda demonstrar os conceitos de domínio público e de bem público.

Primeiramente, cumpre dizer que o termo domínio público é bastante polissêmico. Conforme lembra Hely Lopes Meirelles, “a expressão ‘domínio público’ ora significa o poder que o Estado exerce sobre os bens próprios e alheios, ora designa a condição desses bens." 286

Na mesma linha caminha Di Pietro que, apesar de se valer de um conceito restritivo de domínio público (como o de Cretella Jr.), indica a polissemia da expressão, garantindo ao menos três significados: o sentido mais amplo, que designa o conjunto de bens pertencentes às pessoas jurídicas de direito público interno; em um segundo sentido, que indica aqueles bens afetados a um fim público e em um sentido ainda mais restrito, ligado ao demanio italiano, que entre nós seriam os bens de uso comum do povo (que por não

sindicais dos trabalhadores, das instituições de educação e de assistência social, sem fins lucrativos, atendidos os requisitos da lei." (grifo nosso).

${ }^{286}$ MEIRELLES, Hely Lopes. Direito Administrativo Brasileiro, 16a edição. São Paulo: Revista dos Tribunais, 1991, p.420. 
serem pertencentes ao poder público em sentido estrito, seu titular seria efetivamente o povo. $^{287}$

De fato, ao exame da doutrina estrangeira, percebe-se que são muitos os significados empregados ao termo ao longo da história. Duguit já apontara que a legislação dominialadministrativa francesa de 1790 conceituava o termo domínio público. Citando Barckhausen, observa o autor que à época, os conceitos de domínio público - sinônimo de domínio nacional - e o conceito de domínio privado possuíam a mesma lógica, não se diferenciando de acordo com a matriz pública ou privada do agente possuidor. ${ }^{288}$

Léon Duguit irá, ao longo de sua obra, construir uma teoria sobre o domínio público. Em síntese, apontou o publicista francês como sendo o domínio público "tout les autres dépendances, mobilières ou immobilières, du domaine étatique qui, sous une forme ou sous une autre, comme objet ou comme moyen, sont affectées à un service public"289.

Desta forma, o conceito de domínio público remete à noção prévia de afetação pública, se alia ao que fora descrito aqui por Hely Lopes Meirelles, no sentido de se referir a qualquer bem que esteja afetado a um serviço público específico. Ainda, o termo "tout les autresdépendances”, é empregado aqui por exclusão, já que o constitucionalista francês parte da definição de domínio privado, para depois apontar o conceito de domínio público.

Outro detalhe importante a ser frisado é que, apesar das semelhanças, subsistem diferenças entre o conceito de patrimônio público e de domínio público. O termo afetação - que parece ser a ligação entre ambos - é empregado de forma distinta em um e outro caso. Se a afetação na questão do domínio tem um caráter objetivo, na medida em que significa efetivamente a ligação do bem a um serviço público, a afetação de que fala Duguit ao tratar de patrimônio público é semelhante, mas mais indireta. Como já apontou Bercovici, a afetação de que trata o francês ao discursar sobre o patrimônio público é em verdade uma relação de finalidade do patrimônio, ao que chamou de utilidade pública.

\footnotetext{
${ }^{287}$ DI PIETRO. Maria Sylvia Zanella.Direito Administrativo, 23ạ Edição. São Paulo: Atlas, 2009, p. 673.

${ }^{288}$ DUGUIT, Léon. Traité de Droit Constitutionnel, cit., p. 345.

289 Idem ibidem, p. 352.
} 
Assim, o conceito de afetação, apesar de semelhante, difere do que é empregado na ideia de domínio público. Esta, ao que parece, está mais ligada ao moderno conceito de afetação que, conforme aduz Bandeira de Mello, "é a preposição de um bem a um dado destino categorial de uso comum ou especial." 290

Retornando ao conceito de domínio público, apontou Hely Lopes que ele pode, para a facilitação de seu entendimento, ser subdividido em dois. O primeiro seria o conceito de domínio eminente, e o segundo, o conceito de domínio patrimonial.

O domínio público eminente seria aquele que garante ao Estado submeter à sua vontade todas as coisas de seu território. Enquanto manifestação de soberania interna, não se configura esta ideia como sendo direito de propriedade. Conforme aponta o autor,

"Como expressão da Soberania Nacional não encontra limites senão no ordenamento jurídico-constitucional estabelecido pelo próprio Estado. Esse domínio alcança não só os bens pertencentes às entidades públicas, como a propriedade privada e as coisas inapropriáveis, de interesse público" ${ }^{291}$.

Entretanto, afirma Meirelles que tal domínio não é poder arbitrário, tratando-se de um poder sujeito ao direito, estando condicionado à ordem jurídico-constitucional e aos princípios, direitos e garantias da Constituição. ${ }^{292}$

É nesta mesma linha que caminha Themístocles Brandão Cavalcanti, ao indicar que a expressão "domínio eminente, como poder supremo sobre o território, confunde-se com a própria noção de soberania, como poder supremo sobre as pessoas e os bens."293

Entretanto, é importante apontar que para Cavalcanti este domínio sobre a propriedade privada é apenas potencial, devendo se concretizar apenas pela exigência do interesse público, devendo, enquanto não se verifica tal condicionante, ser o direito de propriedade privada exercido em toda a sua plenitude.

\footnotetext{
${ }^{290}$ MELLO, Celso Antonio Bandeira de. Curso de Direito Administrativo. São Paulo: Malheiros, 28a Edição, 2011 , p.922. Lembra ainda o autor que enquanto a afetação ao uso comum (ligada aos bens de uso comum do povo) se dá pelo destino natural do bem (como ocorre aos mares e rios), a afetação ao uso especial ou ainda ao uso dominical ocorre por ato administrativo próprio, que caracterize o referido bem enquanto tal. ${ }^{291}$ MEIRELLES, Hely Lopes. Direito Administrativo Brasileiro, cit., p. 420.

${ }^{292}$ Idem ibidem, p. 421.

${ }^{293}$ CAVALCANTI, Themístocles Brandão. Tratado de Direito Administrativo, 1a edição, Tomo V. Rio de Janeiro: Freitas Bastos, 1943, p. 16.
} 
Já o domínio público patrimonial é o que recai sobre seus bens, sendo um direito de propriedade pública, referindo-se a todos os bens pertencentes ao Estado. Sob tal domínio, existem subsidiariamente algumas regras da propriedade privada. ${ }^{294}$

Assim, apesar da dificuldade de se aprumar aqui um conceito fechado de domínio público, é possível verificar que de acordo com Duguit e Hely Lopes que o domínio público está tanto ligado ao poder político que o Estado tem dentro de seu território nacional como sendo soberano, quanto à estrita afetação de um bem ao uso da Administração.

Vale a ressalva que este entendimento não é unânime na doutrina. Afiliado à corrente que indica o termo como condicionante do estado que os bens públicos se encontram, José Cretella Junior define o domínio público como sendo "o conjunto de dos bens móveis e imóveis de que é detentora a Administração, afetados quer a seu próprio uso, quer ao uso direto ou indireto da coletividade, submetidos a regime jurídico de direito público derrogatório e exorbitante do direito comum.",295

É a mesma linha que segue Roberto Dromi. Conforme o autor argentino, "o domínio público é aquele que submete um bem ou coisa que está afetado ao uso público, direta ou indiretamente."296

É a afirmação típica do conceito clássico de domínio público, ligada à escola francesa, citada aqui na figura de Léon Duguit e que Di Pietro, como dito, parece ser próxima.

Destes conceitos surgem ainda duas considerações. A primeira é que o conceito de domínio público enquanto domínio eminente guarda - em boa dose - similitude ao que se pode rascunhar como conceito de patrimônio nacional. Este ponto será visto adiante.

\footnotetext{
294 Idem ibidem, p. 421.

${ }^{295}$ CRETELLA Jr. José. Tratado do Domínio Público, 1a edição. Rio de Janeiro: Forense, 1984, p. 29.

${ }^{296}$ DROMI, Roberto. Derecho Administrativo. Buenos Aires: Ediciones Cuidad Argentina, 5a Edição, 1996, p.546.
} 
A segunda consideração é que a doutrina publicista contemporânea, que versa sobre o patrimônio público, trata de diferenciar o que é patrimônio do que são efetivamente os bens públicos.

Apenas a título de exemplificação, cumpre demonstrar que se o patrimônio público abarca todos os bens e direitos pertencentes ao Estado, os bens públicos são definidos como sendo

"todos os bens que pertencem às pessoas jurídicas de direito público, isto é, União, Estados, Distrito Federal e Municípios, respectivas autarquias e fundações de Direito Público, bem como os que, embora não pertencentes a tais pessoas, estejam afetados à prestação de um serviço público"297.

Cumpre ainda referenciar Marcello Caetano, que aponta a coisa pública ${ }^{298}$ como sendo todas as coisas "submetidas por lei ao domínio de uma pessoa coletiva de direito público e subtraídas ao comércio jurídico privado em razão da sua primacial utilidade coletiva."299

Resta ainda apontar que os bens públicos são hoje divididos pela doutrina administrativa. Como aponta Celso Antonio Bandeira de Mello, o Código Civil de 2002 distingue em seu artigo 99 três espécies de bens públicos: os bens de uso comum, que são aqueles destinados ao uso indistinto de todos; os bens de uso especial, que seriam os afetados a um serviço ou estabelecimento público (como as repartições públicas) e os bens dominicais, que seriam os próprios do Estado como objetos de direito real, como os bens das pessoas jurídicas da Administração indireta que tenham estrutura de direito privado, salvo se lei dispuser em contrário. $^{300}$

Por fim, de tudo o que foi visto, falte apenas a referência ao Código Civil Brasileiro.

Desde o início deste tópico apontou-se o surgimento dos conceitos de patrimônio público e domínio público dentro da esfera privada do Direito. Ainda, podemos inferir que a enorme

297 MELLO, Celso Antonio Bandeira de. Curso de Direito Administrativo. São Paulo: Malheiros, 28a Edição, 2011, p. 920.

${ }^{298}$ Sabe-se que a doutrina diverge sobre a similitude do conceito de coisa pública e bem público, muito em função da origem civilista do termo. Dado que o escopo da presente dissertação é apenas tratar de diferenciar bem público de patrimônio e domínio público, usar-se-á a proposição de Caetano, que assemelha os termos coisa e bem público. Para as diferenciações entre bem e coisa, por todos, vide MARQUES NETO, Floriano de Azevedo, Op. cit., p. 49 e SS.

${ }^{299}$ CAETANO, Marcello. Manual de Direito Administrativo, 9a edição, 2a reimpressão. Coimbra: Livraria Almedina, 1983, p. 881.

${ }^{300} \mathrm{Cf}$. MELLO, Celso Antonio Bandeira de. Curso de Direito Administrativo. São Paulo: Malheiros, 28a Edição, 2011, p.921. 
variação doutrinária tendeu a criar termos com concepções se não idênticas, muito parecidas, como no caso dos conceitos de domínio público e bem público.

Esta excessiva confluência de conceitos tende a tornar o tema dos bens públicos extremamente complexo. Como apontou Justen Filho, o motivo talvez seja a origem privatista do debate. $^{301}$

Aparte do debate doutrinário-civil sobre o conceito de bens e bens públicos, cumpre apenas arrolar que o Código Civil Brasileiro indica em seu Título II, Capítulo III o que seriam os bens públicos. Definem-os em sendo os bens do domínio nacional pertencentes às pessoas jurídicas de direito público interno. ${ }^{302}$. Ainda, o Código Civil classifica os bens públicos, conforme apontado por Bandeira de Mello, em seu artigo 99.

Uma vez feitas tais considerações, passamos agora à tentativa de definição do que seria o patrimônio nacional.

\subsubsection{Patrimônio nacional}

Tentar uma definição do que seria o termo patrimônio nacional, não é empreitada tão simples. Ao que consta, o termo não possui grandes referências na doutrina administrativa clássica. Se bem que referenciado na legislação dominial francesa do fim do século XVIII, o termo àquela época não possuía um conceito específico. Como dito, ele era empregado como sinônimo do termo patrimônio público.

Se o conceito descrito foi exaustivamente debatido por toda a doutrina administrativista, de onde inclusive é possível a construção de uma síntese sobre suas variações, apontar um caminho ao conceito de patrimônio nacional pode ser um caminho tortuoso.

\footnotetext{
301 JUSTEN FILHO, Marçal. Curso de Direito Administrativo, 1a Edição. São Paulo: Saraiva, 2005, p. 721.

${ }^{302}$ Ao conceito de domínio nacional, registra-se aqui o conceito dado por Marques Neto: "Vê-se pois que a lei civil pretendeu dar ao conceito de "domínio nacional" uma abrangência de gênero, dentro da qual estão as suas espécies: (i) bens da pessoas jurídicas estatais (v.g., todos os etres da federação e as pessoas de direito público e (ii) bens pertencentes às outras pessoas físicas ou jurídicas, que são bens privados". In MARQUES NETO, Floriano de Azevedo. O regime jurídico das utilidades públicas: função social e exploração econômica, Op. cit., p. 94.
} 
O termo, que aparece vivamente descrito junto ao artigo 219 da Constituição de 1988, é encontrado com mais facilidade nas novas áreas do direito, como o direito ambiental ou o direito urbanístico.

Porém, antes que se tente apontar o que talvez signifique o termo em análise, discorreremos aqui sobre a referência que o texto constitucional de 1988 faz ao mesmo.

Com apenas três referências em nossa constituição, o termo patrimônio nacional aparece primeiramente no inciso I do artigo 49, que dá ao Congresso Nacional a competência exclusiva para resolver sobre tratados ou qualquer ato internacional que resulte em compromissos gravosos ao patrimônio nacional.

A segunda aparição é no já exaustivamente citado artigo 219, que inclui o mercado interno como parte integrante do patrimônio nacional.

Por fim, aparece ainda no parágrafo $4^{\circ}$ do artigo 225 , que compõe o capítulo sobre o meio ambiente da Constituição. Define tal parágrafo que a Floresta Amazônica brasileira, a Mata Atlântica, a Serra do Mar, o Pantanal Mato-Grossense e a Zona Costeira são patrimônio nacional, e só poderão ser explorados na forma da lei e sob condições que garantam sua preservação.

Uma vez pontuado quais são os artigos da Constituição Brasileira que trazem o termo patrimônio nacional, resta dizer o que a doutrina mais contemporânea aponta como possibilidades para o conceito.

A busca por definições que possibilitem a construção de uma definição mais fechada ao termo se inicia pelo direito ambiental. Por ter sido utilizado também no artigo 225 da Constituição de 1988, alguns doutrinadores possuem definições.

Em que pese a ideia de patrimônio nacional não ter sido conceituada a fundo pelo direito ambiental brasileiro, o fato é que este ramo da ciência jurídica dá boas pistas para que a frente se possa construir um panorama mais conclusivo sobre qual seria o sentido que o legislador procurou dar a ele. Alguns doutrinadores que são hoje referência dentro do 
direito do meio ambiente que, se não definem o termo com a profundidade aqui pretendida, podem auxiliar nesta empreitada.

É o caso de Paulo de Bessa Antunes, que vai conceituar o patrimônio nacional como "uma simples manifestação do domínio eminente da nação sobre os bens existentes em seu território, sem que isso implique o esvaziamento do domínio útil ou do domínio pleno."303

Admitindo que o conceito não está pacificado pela doutrina nacional, o autor se esforça em parametrizar o patrimônio público junto ao patrimônio público e social. Paulo de Bessa Antunes segue inferindo que qualquer que seja a operacionalização dada ao termo, ela deve ser feita sob a ótica do interesse comum de todos, em referência ao antigo Código Florestal.

Se a digressão de Antunes parece clarificar as dúvidas que pairam sobre a aplicação do conceito em termos ambientais, ele pouco resolve a questão sob o ponto de vista do artigo 219. Ainda, se a inferência de conceituar o patrimônio nacional enquanto "simples manifestação do domínio eminente da nação" corrobora com o que foi levantado até aqui, nem a caracterização do termo como ligado ao conceito de patrimônio público e social, nem a análise sob a ótica da ideia de interesse comum de todos - ligada ao direito do ambiente - parece dar conta do prescrito no dispositivo que trata do mercado interno em nossa Constituição.

Em primeira monta porque a aplicação do patrimônio nacional como pertencente ao patrimônio público e social responde apenas em parte a dimensão constitucional do conceito de patrimônio não-econômico. Como será trazido adiante, a Constituição faz referência também ao patrimônio histórico, cultural e genético, que poderiam eventualmente ser abarcados no conceito de patrimônio nacional.

Em outros momentos, indica Antunes que o conteúdo do termo não foi definido, sendo conceito jurídico indeterminado e devendo ser preenchido caso a caso. ${ }^{304}$ Trata apenas de demarcar que o Supremo Tribunal Federal reiteradamente vem diferindo-o do conceito de patrimônio público.

\footnotetext{
${ }^{303}$ ANTUNES, Paulo de Bessa. Direito Ambiental, 12ạ edição. Rio de Janeiro: Lumen Juris, 2009, p. 564. ${ }^{304}$ Idem ibidem, p. 68.
} 
Caminho parecido parece ter trilhado outro importante jusambientalista brasileiro. Paulo Affonso Leme Machado, ao tratar da questão da inserção de partes do território nacional como sendo patrimônio nacional, aduz Machado que "[O] texto é pedagógico no dizer que essas áreas integram o 'patrimônio nacional', indicando que os regionalismos não se devem sobrepor aos interesses ambientais nacionais." ${ }^{305}$. Na sequência, o autor cita a jurisprudência do Supremo, alinhando-se a Bessa Antunes, lembra que o STF reiteradamente tratou de diferenciar o patrimônio nacional do patrimônio público.

Aliás, a ideia de diferenciação entre os conceitos de patrimônio público e patrimônio nacional não é nova na doutrina ambiental nacional. Já ao tempo da promulgação da Constituição Brasileira, alguns autores advertiam para a possibilidade de confusão dos termos.

Já em 1989, salientou Pedro Escorel de Azevedo que a garantia dada ao parágrafo $4^{\circ}$ do art. 225 não confere à União o domínio sobre áreas particulares situadas nas regiões mencionadas. ${ }^{306}$ Lembra ainda o autor que não se trata o conceito de letra morta ou norma meramente programática, sem aplicação imediata. Isto porque, aduz o parágrafo “impõe ao legislador ordinário e ao Poder Público a adoção de medidas que diferenciem o tratamento patrimonial dessas áreas no contexto geral do território brasileiro.” ${ }^{„ 307}$

Parece ser a mesma linha que segue Antônio Beltrão. A ressalva que faz o autor é de característica patrimonial. Ao referendar que os termos não se confundem, aponta o autor que qualquer ato estatal que implique limitação específica no potencial de exploração econômica da propriedade, deverá ser indenizado. ${ }^{308}$

Como visto, a doutrina ambientalista parece não resolver de plano o termo aqui estudado. Se bem que tratou de diferenciar o termo de patrimônio público, indicando inclusive que a

\footnotetext{
${ }^{305}$ MACHADO, Paulo Affonso Leme. Direito Ambiental Brasileiro, 15a edição, São Paulo: Malheiros, 2007, p. 141

${ }^{306}$ AZEVEDO, Pedro Ubiratan Escorel de. Reflexos patrimoniais da questão ambiental na administração pública à luz da nova Constituição in CADERNOS FUNDAP, São Paulo, ano 9, dez/1989, pg. 70.

${ }^{307}$ Idem ibidem.

${ }^{308}$ BELTRÃO. Antônio F. G. Curso de Direito Ambiental. Rio de Janeiro: Forense, São Paulo: Método, 2009, p.82.
} 
Suprema Corte brasileira já pacificara o tema, é importante salientar que não há uma conclusão que possa ser levada a termo apenas com o que foi levantado.

Até porque, do exposto por hora, a doutrina jusambiental tratou de, primeiramente, apontar que o conceito de patrimônio nacional deve superar qualquer questão local.

Conforme apontou Leme Machado, o conceito indica, antes de qualquer coisa, que a preservação das áreas garantidas pelo parágrafo $4^{\circ}$ do artigo 225 da Constituição não está relegada apenas às autoridades locais. Sua existência transcende qualquer limitação geográfica, sendo dever de toda a nação sua preservação.

Tal colocação coaduna com o que expôs Bessa Antunes. Conforme apontou o autor, o termo em questão é manifestação da ideia de domínio eminente, que já foi exposta neste trabalho e tem seu âmago imbricado à própria soberania de um Estado. Esta ligação será explorada abaixo, mas por hora, vale dizer que há sim uma relação, à primeira vista, entre os dois conceitos.

Seguindo na busca por mais informações que ajudem a compor uma perspectiva mais completa do conceito na doutrina, passa-se a estudar o que propôs José Afonso da Silva.

O constitucionalista brasileiro talvez tenha sido um dos autores que mais se dedicou a conceituar o termo em referência dentro do direito ambiental. Entretanto, o esforço do autor está concentrado em garantir que os biomas citados no referido parágrafo $4^{\circ}$ tenham seu tratamento constitucionalmente diferenciado respeitado.

Conforme aponta José Afonso da Silva, "o significado primeiro e político da declaração constitucional de que aqueles ecossistemas florestais constituem patrimônio nacional está em que não se admite qualquer forma de internacionalização da Amazônia ou de qualquer outra área."309

A tese desenvolvida por Afonso da Silva é que a preservação dos biomas e sistemas listados pelo dispositivo em comento é essencial para a manutenção da biosfera, de todo o

${ }^{309}$ SILVA, José Afonso da.Direito Ambiental Constitucional, 9ạ edição. São Paulo: Malheiros, 2011, p. 272. 
patrimônio genético e principalmente, a evolução das espécies. Assim, a correta proteção deste patrimônio passa pela manutenção soberana destes territórios.

É possivelmente por isso que o autor aponta como significado primeiro a manutenção da Amazônia ou de qualquer outra área a ser preservada enquanto território nacional. Vemos então que, apesar de seguir caminho diverso, há a plena concordância com a ideia de que o patrimônio nacional, neste caso, está ligado ao conceito de soberania.

Dentro do que se observou até aqui, quando tratado do conceito de patrimônio nacional sob uma perspectiva ambiental, a doutrina nacional tendeu sempre a referenciar o termo ao prescrito pelo legislador constituinte. Ainda, observamos que em todos os casos os autores parecem ter se preocupado mais com a diferenciação do conceito de patrimônio nacional da ideia de patrimônio público do que necessariamente ensinar uma definição mais fechada sobre a ideia de patrimônio nacional.

Procurando então afastar a dogmática ambiental de uma definição do termo que esteja ligada ao artigo 225 da Constituição, olhamos então para a doutrina alienígena.

Analisando a escola jusambiental italiana, o conceito de patrimônio nacional aparece ligado muito mais à doutrina ambiental-cultural do que à preservação ambiental da fauna e flora mais tradicionais, como ocorre no Brasil.

$\mathrm{Na}$ busca por definir o que seria efetivamente o patrimônio cultural nacional, Wanda Cortese tratará antes de definir o que seria o patrimônio nacional. Nesta esteira, Cortese descreverá o patrimônio nacional como sendo toda a riqueza de uma nação, que não se esgota apenas em um escopo econômico ${ }^{310}$. Até porque, como a própria autora aduz, apesar do conceito de nação ser historicamente utilizado como sinônimo de Estado, sabe-se que a ideia de nação é muito mais ampla, abarcando o pensamento, cultura, língua, costume, tradições, religiões e raças presentes dentro de um determinado território.

${ }^{310}$ CORTESE, Wanda. I Beni Culturali e Ambientali: profilinormativi. Padova: CEDAM, 1999, p.101. 
Aponta ainda que, mesmo que o patrimônio conceituado enquanto patrimônio nacional esteja sob a tutela privada, ele deve ser tratado como tal. Até porque, apesar de não guardar uma relação material com o Estado, é ele o responsável por sua tutela.

Sob ótica diversa, parece que mesmo a doutrina italiana mantém bastante proximidade com o que foi trazido até aqui pela academia brasileira. Em primeiro lugar porque em ambos os casos os doutrinadores defendem que apesar da ideia de patrimônio nacional não conferir ao bem assim tutelado status de patrimônio público, devendo ser mantido como propriedade privada (se assim o for), é fato que conferir a um bem - ou conjunto de bens tal característica, é dar a ele uma espécie de tutela potencial do referido bem ao Estado.

Esta linha de raciocínio parece guardar ainda relação com a própria escola administrativista francesa mais contemporânea. Conforme aponta Caroline Chamard, o conceito de patrimônio se distanciou, no direito ambiental, do conceito de propriedade. É da autora a indicação de que trata Bercovici, ao garantir que ao buscar a compreender o que seria o patrimônio em termos ambientais, deve-se "considerar elementos que parecem essenciais e que devem ser transmitidos intactos para as gerações futuras, abordagem esta que também se verifica no âmbito biológico, cultural, paisagístico, arquitetônico, tanto para o meio rural quanto urbano."311.

Ainda, ao apontar o que seria o "patrimônio comum da nação", Chamard se preocupa em garantir que o conceito "reúne coisas que erigem um interessem coletivo e que não são propriedade de alguém singularizado. É o produto da história, e que os homens devem conservar para transmitir a seus sucessores." 312

Vê-se então que o conceito traduzido por Chamard parece coadunar com o que fora dito não só por Bessa Antunes. De fato, a ideia de patrimônio nacional apontada aqui está bastante relacionada, como já dito, com o conceito de domínio (público) eminente.

\footnotetext{
${ }^{311}$ BERCOVICl, Gilberto.Ciência e inovação sob a Constituição de 1988, cit. p. 283 e 284

${ }^{312}$ CHAMARD, Caroline. La Distinction des Biens Publics et des Biens Privés: Contribution à la Notion de Biens Publics, Paris, Dalloz, 2004, p. 557.
} 
Hely Lopes Meirelles identificou o conceito de domínio eminente como sendo o "poder político pelo qual o Estado submete à sua vontade todas as coisas de seu território. É uma das manifestações da Soberania interna; não é direito de propriedade." 313

Ou seja, o domínio eminente não é o direito de propriedade em si. Como aponta Meirelles, citando Basavilbaso, este domínio é o poder que o Estado exerce potencialmente sobre as pessoas e os bens que se encontram no seu território. ${ }^{314}$ Em termos objetivos, é por meio deste domínio que é conferido ao Estado o poder de limitação à propriedade, as servidões administrativas e qualquer outra medida de polícia.

Ao que foi apontado até aqui, parece que a ideia de patrimônio nacional guarda relação direta com esse conceito.

Como demonstrado, a lógica que parece ter permeado a noção de patrimônio nacional parece estar calcada em primeiro lugar em uma ideia de totalidade, pois trata de algo menos ligado a uma pessoa singularizada e sim a um todo social, ou como apontou Chamard, do interesse coletivo.

Em segundo lugar, a noção de patrimônio nacional parece transcender a lógica patrimonialista civilista não apenas pela sua impessoalidade, mas também por diferir de uma colocação meramente econômica. Este ponto é muito bem demonstrado pela doutrina do direito ambiental, que aponta o caráter extra-econômico do conceito, ao qual a própria ideia de nação parece pertencer.

Por fim, concorda-se aqui que se a ideia de patrimônio nacional é avessa a um controle privado, no sentido do direito de propriedade, há nele uma potencialidade de controle por um ente específico: o Estado. Respeitando os limites jurídicos-constitucionais, assim como na conceituação de domínio eminente, a noção de patrimônio nacional, se não dá ao Estado a titularidade da propriedade, garante a ele meios para intervir no domínio privado para a sua manutenção.

\footnotetext{
${ }^{313}$ MEIRELLES, Hely Lopes. Direito Administrativo Brasileiro, cit., p. 420.

${ }^{314}$ Idem ibidem, p. 421.
} 
Estes apontamentos parecem não estarem isolados na doutrina administrativista. Conforme conceituou Floriano Azevedo Marques Neto, o patrimônio nacional "se aproximaria da noção de domínio eminente e compreenderia tudo que possua valor para a coletividade no âmbito do país, independentemente de pertencer ou não ao domínio de entes públicos". 315

Ainda, a proposição de Marques Neto parece conseguir entrelaçar as outras duas referências constitucionais ao termo.

Ao que tudo indica, tanto ao garantir ao Congresso Nacional a exclusividade em celebrar acordos ou tratados internacionais que resultem em compromissos gravosos ao patrimônio nacional, quanto nas já aduzidas questões ambientais e também na defesa da noção de mercado interno, o que parece ser o nó górdio que dá um único sentido ao termo patrimônio nacional parece ser a defesa da soberania nacional.

É através do fio condutor da manutenção do Estado brasileiro enquanto ente soberano que se traça assim um esboço terminológico para o que poderia ser garantido pelo termo patrimônio nacional.

No caso da fixação dos tratados, a soberania nacional deve ser expressa pelo Congresso Nacional, que nas democracias representativas é a expressão máxima de representação do cidadão e dos próprios Estados-membros.

Já no caso ambiental, a manutenção das áreas como a Amazônia, o Pantanal e a Mata Atlântica se dá não apenas por uma questão de preservação ambiental. Ao dar o status de patrimônio nacional a esses e outros ecossistemas do país, o legislador constitucional elevou tais áreas à parte integrante de um conjunto de bens que não podem ser medidos exclusivamente como bens econômicos. A conservação de tais áreas é expressão da soberania da nação, que não deve nem poderá internacionalizá-las.

E, por fim, a soberania também é a pedra de toque do conceito de patrimônio nacional, presente no artigo 219 da Constituição.

${ }^{315}$ MARQUES NETO, Floriano de Azevedo. O Regime Jurídico das Utilidades Públicas, cit., p.60. 
A soberania de que trata o artigo em questão é a soberania econômica da nação. Além de não ter de se sujeitar aos interesses econômicos de outros Estados, deverá, para garantir o bem-estar de todos os seus cidadãos, dar ao mercado interno o tratamento de patrimônio nacional, assegurando a independência econômica, tecnológica e social ao povo brasileiro. É este o ponto que se desenvolverá no próximo tópico.

4.5. Esboço interpretativo do artigo 219

Em primeiro lugar, cumpre transcrever o dispositivo, aqui referido à exaustão.

Art. 219. O mercado interno integra o patrimônio nacional e será incentivado de modo a viabilizar o desenvolvimento cultural e sócio-econômico, o bem-estar da população e a autonomia tecnológica do País, nos termos de lei federal.

Inicia-se assim este esboço interpretativo pela junção dos conceitos.

Pelo conceito de mercado interno, vimos tratar mais do que apenas o espaço geográfico delimitado pelas fronteiras de um país para realizar trocas mercantis. Ao contrário desta conceituação simplista, a noção de mercado interno, como visto, pode ser bem mais ampla.

Em primeiro lugar, lembramos que, em termos geográficos, o limite do mercado interno é, por óbvio, o espaço internacionalmente delimitado à determinada nação.

Entretanto, ao que nos parece, a ideia de mercado interno comporta mais do que as relações de trocas mercantis. Fazem parte do conceito de mercado interno os produtores e consumidores de bens e serviços, mas não só. Pertence a ele também o mercado de trabalho, ou seja, toda a população economicamente ativa de um país.

Isso implica em outra consideração: sob a ótica das relações humanas, devem-se incluir no mercado interno todas as relações de produção. 
Isto porque, como demonstram Marx e Lênin, o mercado interno é o espaço de circulação do capital em determinado país. Em seu conceito contemporâneo, mercado interno comporta todos os espaços tocados pela circulação do capital.

Outra característica é seu tempo histórico. Ao contrário das relações de troca, que existem desde os primórdios da humanidade, o mercado interno é produto do capitalismo. Surge com a destruição da primitiva economia de trocas, pela inserção do trabalho assalariado e da renda da terra. É após a acumulação primitiva do capital que nascem as condições propícias para o surgimento do mercado interno.

É assim, portanto, um produto do capitalismo para o capitalismo, devendo ser tratado nestes termos. Organiza-se em torno da circulação de capital, e não só da moeda. Não é um simples espaço de trocas mercantis. Mesmo dentro das análises furtadianas, nota-se que há um forte componente social, que transcende a mera análise mercantil. Na verdade, o mercado interno nas teses nacionais-desenvolvimentistas tem papel central não só por concentrar as transações econômicas, mas por conter em si um sentido de auto-afirmação social. Para Furtado, potencializar o mercado interno é potencializar as relações humanas daquele país, garantindo ao seu povo o direito de definir seu destino e viver na plenitude sua soberania.

Desta forma, vemos que o mercado interno possui um duplo sentido: o primeiro, monetário, porque abarca todo o domínio econômico nacional. O mercado interno torna-se assim, sinônimo de domínio econômico, que pelo entendimento de Albino de Souza seria a somatória das atividades econômicas de uma nação. ${ }^{316}$

Em outro aspecto, mais amplo, o mercado interno é o espaço nacional de circulação do capital, devendo este entendimento abarcar o conceito de domínio econômico nacional, transcendendo para a ideia de um espaço de circulação não só da moeda, mas também do capital - que pode ser sucintamente definido como o produto, a riqueza derivada desta própria circulação.

${ }^{316}$ SOUZA, Washington Peluso Albino de. Direito Econômico. São Paulo: Saraiva, 1980, p. 398. 
Esse entendimento sobre o mercado interno fica mais nítido conforme se avança na leitura do artigo 219.

Ao imputar ao mercado interno ser parte integrante do patrimônio nacional, o legislador não o introduziu, por óbvio, como parte do patrimônio estatal. Vimos que o conceito de patrimônio nacional, há algum tempo em desuso, diz respeito à potencialidade de um Estado em dispor do referido patrimônio.

Em outras palavras, o patrimônio nacional não é um rol de bens pertencentes à União. Como visto, o patrimônio nacional guarda íntima relação com o conceito de domínio eminente. Manifestação da soberania interna - como pontuou Hely Lopes Meirelles - o domínio eminente é a potencialidade que o Estado tem sobre a coisa alheia, em função da posição estratégica daquele bem para a manutenção de sua soberania, ou melhor dizendo, de sua própria existência.

Talvez por isso o conceito de patrimônio nacional tenha sido estendido, dentro da Constituição de 1988, às reservas naturais. Os motivos são óbvios: ainda que nossos biomas estejam divididos em inúmeras propriedades privadas, sua manutenção é de interesse do Estado, representante legítimo do povo soberano. Seja pelos motivos ambientais ou mesmo de exploração de recursos naturais, a manutenção da Floresta Amazônica e do Pantanal, por exemplo, é de tal importância que a Constituição conferiu ao Estado o domínio potencial sobre tais biomas. Caso sejam ameaçados, tem a Administração o direito-dever de intervir no sentido de preservá-los.

Este entendimento relativo às florestas parece ser extensivo ao mercado interno, como visto no artigo 219.

Ao garantir que o mercado interno deve ser incentivado para a promoção do desenvolvimento econômico, social e cultural do país, garantindo-o como parte integrante do patrimônio nacional, a Constituição conferiu ao Estado o domínio potencial sobre tal mercado. 
Isso significa que, nos mesmos moldes do entendimento ambiental - previsto no artigo 225 da Constituição e que conferiu caráter estratégico a alguns biomas nacionais, o legislador constitucional deu ao mercado interno o status de domínio potencial.

O domínio potencial confere ao Estado a possibilidade de interferência no direito de propriedade privada por questões de soberania.

Desta forma, infere-se que, indiretamente, o texto da Constituição garantiu ao mercado interno sua característica privada, corroborando com sua característica histórica, de ser oriundo do modo de produção capitalista. Porém, ao mesmo tempo, dá ao ente público a possibilidade de intervenção, fundado em questões de soberania.

Ao continuar na leitura do referido artigo, observamos que a forma primordial de intervenção no mercado interno será por meio de incentivos, que viabilizem o desenvolvimento cultural e sócio-econômico, o bem-estar da população e a autonomia tecnológica do País.

Ou seja, o artigo primeiramente pressupõe que o Brasil é ainda um país subdesenvolvido, na medida em que infere que o desenvolvimento cultural e sócio-econômico, o bem-estar da população e a autonomia tecnológica do país precisem ainda ser viabilizados. Parte então, o legislador constitucional, do diagnóstico formalmente iniciado no primeiro quartel do século XX, de que o Brasil é um país subdesenvolvido.

Em segundo lugar, o artigo dá ao Estado a possibilidade de intervir no mercado interno. Em termos práticos, isso significa dizer que o artigo 219 é, sob determinada perspectiva, a garantia de intervenção do Estado no domínio econômico, por questões de soberania. Assim, qualquer ato atentatório ao mercado interno pode ser encarado como ato atentatório à soberania nacional.

Outro ponto a ser destacado aqui é que o incentivo ao mercado interno é uma ação positiva do Estado, buscando o desenvolvimento, bem-estar da população e a autonomia tecnológica. Todos estes itens, sem exceção, povoaram a pauta desenvolvimentista durante os primeiros dois terços do século XX. De fato, muito da interrupção do debate sobre a 
pauta do desenvolvimentismo de matriz nacionalista se deu em função do golpe de Estado de 1964, que curiosamente implantou um modelo de desenvolvimento que aqui foi chamado de "não nacionalista", com ampla participação do capital estrangeiro no mercado interno nacional.

Em outra medida, há também a discussão sobre a posição topográfico-constitucional do artigo 219. Vimos que importantes constitucionalistas indicam que o dispositivo deveria estar inserido dentro do capítulo sobre a ordem econômica, por tratar de assunto correlato.

Em primeiro lugar, cumpre dizer que para o direito constitucional econômico, este debate não é de grande relevância. Viu-se que a chamada constituição econômica formal não se delimita por seções ou capítulos da Constituição. Todo e qualquer conteúdo que expressar alguma vinculação econômica deve fazer parte da referida constituição econômica formal.

Em segundo lugar, pontuamos que para a economia política do desenvolvimento econômico, a inovação é parte fundamental do processo de desenvolvimento. Seja pela iniciativa privada, seja pelo setor público, o progresso técnico é parte integrante do processo de desenvolvimento. Em verdade, a inovação é intrínseca ao desenvolvimento econômico.

Desta maneira, a questão do mercado interno estar localizado dentro do capítulo de ciência e tecnologia apenas corrobora para o entendimento de que este artigo confere ao modelo de desenvolvimento um viés nacionalista.

Por fim, a necessidade de regulamentação, além de expressa, é óbvia. Qualquer ação do Estado Democrático de Direito deve estar delimitada pela devida regulação legal. Entretanto, isso não quer dizer que a intervenção do Estado no mercado interno - ou domínio econômico - se proceda de forma estanque, devendo ser regulada por lei única. Todas as formas de intervenção do Estado no mercado interno são definidas em lei, o que significa dizer que este artigo contém em si um viés autorizativo, uma vez que o Estado sempre intervém no domínio econômico. 
Por óbvio, o esforço aqui empreendido não é conclusivo e nem poderia ser, dado se tratar de dissertação de mestrado. O que não se pode negar é que este artigo, na forma em que está previsto, possui um conteúdo com um recorte tipicamente desenvolvimentistanacionalista.

De outra monta, os esforços desta dissertação se focaram na análise de um único artigo constitucional. Em alguns pontos desta pesquisa se mencionou a interação do prescrito no art. $3^{\circ}$, II e III e art. 170, VII e VIII. Apesar deles não terem sido abordados, a análise combinada destes com o artigo 219 parece não apenas garantir o desenvolvimento como meta nacional como também sugere um modelo específico de desenvolvimento.

Dado que o texto constitucional apresenta o desenvolvimento nacional como objetivo da República e indica que a ordem econômica tem como princípio o pleno emprego e a redução das desigualdades regionais, o que se vê é um esforço do legislador constitucional em garantir um modelo específico de desenvolvimento: o furtadiano.

É o que se sugerirá na conclusão. 


\section{CONCLUSÃO}

Vimos que os textos constitucionais dirigentes seriam aqueles que possuem dispositivos dotados de comando ao poder público. Observamos também que, para Canotilho, tais comandos seriam específicos: constituírem tarefas que configurem um programa ao Estado. Talvez por isso tenha o constitucionalista português dito que a constituição dirigente seja sinônimo da adoção da realidade enquanto tarefa.

Outra questão a ser lembrada aqui é o fato de que os dispositivos dirigentes se transfiguram no que Eros Grau convencionou chamar de normas-objetivo, aqui definidas como normas programáticas, em respeito às proposições de Canotilho.

Tal característica confere ao Estado a vinculação de suas ações aos objetivos propostos na norma. Desta forma, uma vez apontado como norma-objetivo, o artigo 219 deve ser observado como vinculante da ação estatal para a perseguição dos objetivos nele contidos.

Esta dissertação assumiu o que a maioria dos constitucionalistas parece acreditar: a Constituição da República Federativa do Brasil, de 1988, é uma típica constituição dirigente. Possui, em larga escala inclusive, artigos programáticos, que dirigem a ação estatal. Ainda, partem de uma análise da conjuntura real e tratam de indicar um caminho a seguir, para que se chegue a outro.

Outra base teórica importante para esta dissertação foi a noção de constituição econômica.

Foi dito aqui que, ao longo do século XX, absorvendo as novas estruturas oriundas das lutas sociais iniciadas no século anterior, as nascentes constituições nacionais tratariam de inserir em seu corpo dispositivos que versassem sobre a vida econômica "em sentido amplo" de suas sociedades.

Ou seja, mais do que garantir instrumentos econômicos como a propriedade privada, as constituições começaram a trazer em si dispositivos de regulação da economia nacional. Da função social da propriedade até aspectos da intervenção do Estado na atividade econômica, os novos textos constitucionais começaram a abrigar comandos de 
interferência na realidade econômica. Aos poucos, as cartas constitucionais deixaram de ter um escopo econômico liberal, fundado na não intervenção da atividade econômica privada, para assumir um caráter mais intervencionista.

Esta importante característica também é parte do ideário da Constituição de 1988. São muitos os exemplos de dispositivos que tratam da vida econômica da nação. De fato, há um capítulo que foi reservado apenas para cuidar da ordem econômica brasileira.

É possível perceber dentro do texto constitucional o fenômeno advindo da somatória de uma constituição dirigente e seus dispositivos econômicos: há, dentro da Constituição de 1988, artigos que são programáticos, advindos da concepção dirigente do referido texto, ao passo que são classificados como dispositivos pertencentes à constituição econômica brasileira.

Dentre tais dispositivos, destacam-se alguns como, por exemplo, os que tratam do desenvolvimento nacional. Observamos aqui que normas que discutam o desenvolvimento são necessariamente fundadas no duplo sentido já mencionado.

Tudo porque a ideia de desenvolvimento pressupõe, em primeiro lugar, uma análise conjuntural que traduza uma realidade de subdesenvolvimento e que prescreva sua superação, fazendo com que a nação atinja o estágio desejado de país desenvolvido. Compreende assim, um comando à nação com o objetivo de alterar o estado de coisas do país, levando-o à situação diversa da qual se encontra.

Em segundo lugar porque qualquer artigo que trate sobre a projeção do Estado em direção ao desenvolvimento há de ser programático. Consiste em um artigo que configura as ações do Estado em torno de um programa, que se prolonga no tempo.

Por fim, o mais óbvio, mas não menos importante, dado que o desenvolvimento de uma nação pressupõe o desenvolvimento econômico, qualquer dispositivo constitucional que trate do tema será, decerto, um artigo da constituição econômica em sentido formal, que é o texto econômico-constitucional propriamente dito. 
Para esta pesquisa, escolhemos o artigo 219. Repetido exaustivamente nesta dissertação, o texto do referido artigo trata de integrar o chamado mercado interno dentro do patrimônio nacional, devendo ser incentivado para promover o desenvolvimento cultural, econômico, social e tecnológico, garantindo o bem-estar a todos.

Este dispositivo, como se pode ver, preenche todos os requisitos aqui elencados: é norma programática, possui conteúdo dirigente e faz parte da constituição econômica.

Apesar disso, verificamos ao longo do terceiro capítulo desta dissertação que o tratamento dado a ele é, no mais das vezes, estanque ao que foi elencado aqui. Ora se valendo como dispositivo garantidor da economia de mercado, ora como mero artigo protecionista, o referido texto constitucional foi inclusive patenteado como sendo dotado de um nacionalismo xenófobo e ultrapassado.

Porém, desconfiando destas colocações e amparando-se no estudo da economia política do desenvolvimento pensada no Brasil entre 1930 até os dias de hoje, esta pesquisa chega a sua conclusão com uma proposta diferente e ainda minoritária dentro do Direito Econômico brasileiro.

Como se pode analisar, a proteção do mercado interno como fonte do desenvolvimento econômico é ação fundamental no modelo de desenvolvimento que Ricardo Bielschowsky classificou como desenvolvimentista de tipo nacionalista.

A corrente comumente conhecida como nacional-desenvolvimentismo foi gestada dentro dos pressupostos teóricos dos economistas alinhados à Cepal - Comissão Econômica para a América Latina. Entre seus maiores expoentes está Celso Furtado, considerado por muitos como o maior economista brasileiro.

Suas prescrições tratam de dar ao Estado o papel central da condução do processo de desenvolvimento econômico. Através do planejamento e da ação direta do Estado dentro do domínio econômico, o desenvolvimentismo furtadiano primou por formular teses que desloquem o centro dinâmico do país de sua matriz agrário-exportadora para o setor industrial. Pressupõe também a internalização dos centros de decisão, ou seja, que as 
decisões da vida econômica da nação sejam tomadas dentro das fronteiras nacionais, preferencialmente coordenadas pelo Estado.

Mas o mais importante desta tese é que toda a força motriz que mantém o processo de industrialização se lastreia na consolidação do mercado interno. É através de um mercado interno sólido que o modelo nacional-desenvolvimentista prima por caminhar para a superação do subdesenvolvimento.

Mais do que um elemento de importância na tese furtadiana, o mercado interno é o centro, de onde orbitam as ações estatais no sentido de promover o desenvolvimento. É exatamente isto que Furtado quis dizer ao salientar que o desenvolvimento econômico de um país depende da internalização dos centros de decisão - será a nação que decidirá o que para que e para quem produzir. Tudo isso através do deslocamento da matriz econômica do modelo exportador de commodities para um modelo fundado na autonomia industrial nacional. Aqui, lembramos que a autonomia industrial depende de uma independência tecnológica, dado que Furtado, valendo-se de Prebisch, adotou como base a relação centroperiferia, onde os países periféricos assim se classificam, dentre outros motivos, em face de sua dependência tecnológica.

Este conceito possui franca similitude com o prescrito no referido artigo 219, qual seja, de que o mercado interno integra o patrimônio nacional.

Isso porque, observamos que das compreensões possíveis do termo patrimônio nacional, o que mais parece se adequar é a ideia de domínio iminente. Ligado ao pressuposto da soberania nacional, o domínio iminente diz respeito à potencialidade que o Estado tem de interferir na propriedade privada para a manutenção da soberania nacional.

A conjunção do significado da intervenção potencial do Estado no mercado interno é então uma espécie de tradução de toda a tese furtadiana sobre o desenvolvimento nacional.

Por tudo isso, concluímos esta dissertação afirmando de forma categórica que o artigo 219 é uma síntese cristalina do pensamento furtadiano. Incentivar o mercado interno para a promoção do desenvolvimento, garantindo sobre ele a possibilidade de intervenção estatal 
não é outra coisa senão todo o legado de Celso Furtado. Todo seu esforço teórico pode ser traduzido em uma leitura lúcida das limitações econômicas nacionais no processo de desenvolvimento econômico, utilizando o processo de nacionalização da produção industrial como motor para a superação do subdesenvolvimento brasileiro.

E por subdesenvolvimento entende-se não a consecução de uma curva crescente do produto interno bruto. Subdesenvolvimento pressupõe desigualdade, que era e é a marca do Brasil, que figura entre as vinte nações mais desiguais do mundo ao passo que caminha com folga entre os dez maiores PIBs da humanidade.

A questão a ser levantada aqui seria o motivo de as políticas de Getúlio Vargas, Juscelino Kubitschek e João Goulart, uma vez recolocadas depois do interregno ditatorial brasileiro, nunca mais tenham sido praticadas, ainda que expressamente previstas no texto constitucional.

A resposta parece remeter ao início desta pesquisa. Como bem lembrou Canotilho, o problema central de realização das constituições dirigentes é sua legitimação. Ou seja, entre suas previsões dirigente-programáticas e sua concretização, há a necessidade de legitimação. Porque, apesar de muitos constitucionalistas não tocarem mais na questão, as constituições são as mais políticas das peças legislativas e não só. Em verdade, o Direito Constitucional, como precisamente apontou Bercovici, é o direito da política, e da política do Estado.

Assim, o que de fato há é um descolamento das forças políticas que construíram o texto constitucional daquelas que a aplicaram. O processo constituinte, até agora, parece não ter se legitimado politicamente: desde o governo de Fernando Collor, todo o cerne da política econômica mundial se organizou em torno do projeto neoliberal, franco opositor do modelo furtadiano, desde sempre.

Por fim, mas não menos importante, colocamos o último desejo desta pesquisa. Se algum dia for debatido a hipotética recolocação do conteúdo do artigo 219 em outro capítulo, seção ou parte da Constituição brasileira, este pesquisador roga para que seja inserido não dentro do capítulo sobre a ordem econômica ou sobre a ciência e tecnologia. De fato, tudo 
leva a crer que o local mais apropriado para o conteúdo previsto no artigo 219 seja junto aos ditames da soberania nacional, porque parece ser disso que o dispositivo trata. Nada mais atual em tempos como o nosso. 


\section{BIBLIOGRAFIA}

ALBUQUERQUE. Eduardo da Motta e. Celso Furtado, a polaridade modernizaçãomarginalização e uma agenda para a construção dos sistemas de inovação e de bem-estar social. In: SABOIA, João; CARVALHO, Fernando J. Cardim de. Celso Furtado e o século XXI. Barueri: Manole; Rio de Janeiro: Instituto de Economia da Universidade Federal do Rio de Janeiro, 2007.

ALMEIDA, Mansueto. A CF/88 e as políticas de incentivo à CT\&I brasileiras. In: CARDOSO Jr., José Celso. A Constituição Brasileira de 1988 Revisitada: Recuperação Histórica e Desafios Atuais. Brasília: IPEA, 2009.

ANTUNES, Paulo de Bessa. Direito Ambiental, 12a edição. Rio de Janeiro: Lumen Juris, 2009.

AUBRY, Charles; RAU, Frederic Charles.Cours de Droit Civil Français D’Aprés la Méthode de Zachariae, $5^{\text {a }}$ edição. Paris: Marchal etBillard, 1897.

AZEVEDO, Pedro Ubiratan Escorel de. Reflexos patrimoniais da questão ambiental na Administração Pública à luz da nova Constituição in CADERNOS FUNDAP, São Paulo, ano 9, pg 67 a 76, dez/1989.

BAER, Werner. A industrialização e o desenvolvimento econômico do Brasil. $7^{\mathrm{a}}$ Edição. Rio de Janeiro: Editora FGV, 1988.

BASTOS, Celso Ribeiro; MARTINS, Ives Gandra. Comentários à Constituição do Brasil. $2^{a}$ Edição. São Paulo: Saraiva, 2000.

BELTRÃO. Antônio F. G. Curso de Direito Ambiental. Rio de Janeiro: Forense, São Paulo: Método, 2009. 
BERCOVICI, Gilberto. A problemática da Constituição Dirigente: algumas considerações sobre o caso brasileiro. Revista de Informação Legislativa. Ano XXXVI, nº 142 abr./jun. 1999.

Desigualdades Regionais, Estado e Constituição. São Paulo: Max Limonad, 2003

Estado, Soberania e Projeto Nacional de Desenvolvimento. In: Revista LatinoAmericana de Estudos Constitucionais. Belo Horizonte: Del Rey, v. 1, nº 1, 2003. A constituição dirigente e a crise da teoria da Constituição. In Teoria da Constituição. Estudos sobre o lugar da política no Direito Constitucional. Rio de Janeiro: Lumen Juris, 2003.

Constituição e estado de exceção permanente: atualidade de Weimar. Rio de Janeiro: Azougue Editorial, 2004.

Constituição econômica e desenvolvimento: uma leitura a partir da Constituição de 1988. São Paulo: Malheiros, 2005.

A constituição dirigente e a constitucionalização de tudo (ou do nada). In A Constitucionalização do Direito. Fundamentos Teóricos e Aplicações Específicas. Rio de Janeiro: Lumen Juris, 2007.

Soberania e constituição: para uma crítica do constitucionalismo. São Paulo:

Quartier Latin, 2008.

Os princípios estruturantes e o papel do Estado. In: CARDOSO Jr., José Celso (org.). A Constituição Brasileira de 1988 Revisitada: Recuperação Histórica e Desafios Atuais. Brasília: IPEA, 2009.

Ciência e inovação na Constituição de 1988. In:Revista dos Tribunais, v. 101, nº 916, São Paulo: Revista dos Tribunais, 2012.

BEVILAQUA, Clovis. Theoria Geral do Direito Civil, 2a edição. Rio de Janeiro: Livraria Francisco Alves, 1929.

BIELSCHOWSKY, Ricardo (org.). Cinquenta anos de pensamento na CEPAL. Rio de Janeiro: Record: CEPAL, 2000.

Pensamento econômico brasileiro: o ciclo ideológico do desenvolvimentismo. $4^{\mathrm{a}}$ Edição. Rio de Janeiro: Contraponto, 2000. 
BIELSA, Rafael. Derecho Administrativo. Buenos Aires: La Ley, 6 edição, 1964.

BONAVIDES, Paulo. Curso de Direito Constitucional. São Paulo: Malheiros, $24^{\text {a }}$ Edição, 2009.

BORGES, Maria Angélica. Eugênio Gudin: as controvérsias do capitalismo caboclo.

Revista de Economia Política, vol. 20, nº 4 (80), outubro-dezembro de 2000. BRASIL. Ministério do Planejamento e Coordenação Econômica. Programa de ação econômica do governo - 1964-1966.2 edição. Brasília, maio de 1965.

BRAUDEL, Fernand. Civilização material, economia e capitalismo, séculos XV-XVIII, vol. 2 - os jogos das trocas. São Paulo: Martins Fontes, 1998.

BRESSER -PEREIRA, Luiz Carlos. [online]. O conceito histórico de desenvolvimento econômico. Disponível em:

http://www.bresserpereira.org.br/papers/2008/08.18.ConceitoHist\%C3\%B3ricoDesenvolvi mento.31.5.pdf .

. [online]. Desenvolvimento econômico e revolução capitalista. Disponível em:http://www.bresserpereira.org.br/papers/2008/08.19.DesenvolvimentoERevolu\%C3\% A7aoCapitalista.20.6.pdf [online]. Tendência declinante da taxa de lucro. Disponível em: http://www.rep.org.br/pdf/24-2.pdf. ; REGO, José Marcio. A grande esperança em Celso Furtado: ensaios em homenagem aos seus 80 anos. São Paulo: Ed. 34, 2001. Interpretações sobre o Brasil. In Maria Rita Loureiro, org. (1997) 50 anos de Ciência Econômica no Brasil. Rio de Janeiro: Editora Vozes, 1997.

BULHÕES, Octávio Gouvêa de. Economia e nacionalismo. Revista Brasileira de Economia. Vol. 6, $\mathrm{n}^{\mathrm{o}}$ 1, 1952. Economia e política econômica. Rio de Janeiro: Livraria Agir Editora, 1960.

CAETANO, Marcello. Manual de direito administrativo, $9^{\mathrm{a}}$ edição, $2^{\mathrm{a}}$ reimpressão. Coimbra: Livraria Almedina, 1983. 
CAMARGO, Ricardo Antônio Lucas. Direito econômico e direito administrativo: $o$ Estado e o poder econômico. Porto Alegre: Sergio Fabris Editor, 2006.

CAMPOS, Roberto. Planejamento do desenvolvimento econômico de países subdesenvolvidos. DigestoEconômico, São Paulo, abril de 1952.

Inflation and balanced growth. In: ELLIS, H. (ed.) Economic Development for Latin America. Londres: Macmillan, 1961. A lanterna na popa: memórias. Rio de Janeiro: Topbooks, 1994.

CANOTILHO, José Joaquim Gomes. Constituição dirigente e vinculação do legislador. $1^{\mathrm{a}}$ edição, Reimpressão, Coimbra: Coimbra Editora, 1994.

Constituição dirigente e vinculação do legislador: contributo para a compreensão das normas constitucionais programáticas. $2^{\text {a }}$ Edição, Coimbra: Coimbra Editora, 2001. Rever ou romper com a constituição dirigente: em defesa de um constitucionalismo moralmente reflexivo. In. Doutrinas Essenciais de Direito Constitucional, São Paulo: Editora Revista dos Tribunais, 2011, Tomo I.

CARONE, Edgard (org.). Evolução industrial do Brasil e outros estudos. São Paulo: Editora Nacional: Editora USP, 1973.

CAVALCANTI, Themístocles Brandão. Tratado de direito administrativo, $3^{\mathrm{a}}$ edição, Tomo III. Rio de Janeiro: Freitas Bastos, 1956. Tratado de direito administrativo, $1^{\mathrm{a}}$ edição, Tomo V. Rio de Janeiro: Freitas Bastos, 1943.

CHAMARD, Caroline. La Distinction des Biens Publics et des Biens Privés: Contribution à la Notion de Biens Publics, Paris, Dalloz, 2004.

COMPARATO, Fabio Konder. O indispensável direito econômico in. Revista dos Tribunais, São Paulo, vol. 353, 1955. 
CORTESE, Wanda. I Beni Culturali e Ambientali: profili normativi. Padova: CEDAM, 1999.

COUTINHO. Jacinto Nelson de Miranda (org.). Canotilho e a constituição dirigente. $2^{\mathrm{a}}$ edição, Rio de Janeiro: Renovar, 2005.

CRETELLA Jr. José. Tratado do Domínio Público, $1^{\text {a }}$ edição. Rio de Janeiro: Forense, 1984.

DI PIETRO. Maria Sylvia Zanella. Direito administrativo, $23^{\mathrm{a}}$ Edição. São Paulo: Atlas, 2009.

DUGUIT, Léon. Traté du Droit Constitutionnel, $3^{\mathrm{a}}$ edição, vol. III. Paris : Ancienne Librarie Fontemoing \& Cie, 1930.

ÉCHAUDEMAISON, Claude-Danièle. Dictionaire dÉconomie et de Sciences Sociales. Paris: Édition Nathan, 2001.

FABRIS, Fernando Smith. A Noção jurídica de mercado no direito brasileiro. Tese (Doutorado em Direito), UFRS, 2006.

FERRAZ Jr. Tercio Sampaio. Regulação da ordem econômica.Cadernos de Direito Constitucional e Ciência, - Janeiro-Março de 1997, ano 5, nº 18, RT, São Paulo, pp. 95-98. . Zona Franca de Manaus e incentivos fiscais do setor de informática. In. Direito Constitucional. Liberdade de fumar, privacidade, Estado, direitos humanos e outros temas. Barueri: Manole, 2007, pp. 321-333.

FERREIRA, Pinto. Comentários à Constituição Brasileira. São Paulo: Saraiva, 1995.

FERREIRA FILHO, Manoel Gonçalves. A Nova Constituição Brasileira: constituiçãodirigente ou constituição-plano. In Revista Convivium nº 6. Mimeo, 1988. . Direito Constitucional Econômico. São Paulo: Saraiva, 1990. . Comentários à Constituição Brasileira de 1988, vol4. São Paulo: Saraiva, 1995. 
Princípios fundamentais do Direito Constitucional. São Paulo: $2^{\mathrm{a}}$ edição, Saraiva, 2010.

FORSTHOFF, Erns. Tratado de Derecho Administrativo. Tradução ao espanhol da $5^{\text {a }}$ edição alemã. Madrid: Instituto de Estudios Politicos, 1958.

FURTADO, Celso. A pré-revolução brasileira. Rio de Janeiro: Fundo de Cultura, 1962. . Cultura e desenvolvimento em época de crise. $2^{\mathrm{a}}$ edição. São Paulo: Paz e Terra, 1984.

. Teoria e política do desenvolvimento econômico, $10^{\mathrm{a}}$ edição, Paz e Terra, São Paulo, 2000.

. Os desafios da nova geração. Revista de Economia Política 24(4): 483-486.

Discurso na cerimônia de abertura da III Conferência Internacional Celso Furtado, Rio de Janeiro, URFJ, 2004.

Desenvolvimento e subdesenvolvimento. Rio de Janeiro: Contraponto: Centro Internacional Celso Furtado, 2009.

Formação econômica do Brasil: edição comemorativa: 50 anos. São Paulo:

Companhia das Letras, 2009.

GUDIN, Eugênio. O caso das nações subdesenvolvidas. Revista Brasileira de Economia. Rio de Janeiro vol6, $\mathrm{n}^{\mathrm{o}}$ 3, 1952.

Preliminares sobre a reforma agrária. Digesto Econômico, São Paulo, 18 (162), novembro-dezembro de 1961. Análise de problemas brasileiros. Rio de Janeiro: Agir, 1965.

GUIMEIRO, Rafael Gonçalves. Diálogo das teses do subdesenvolvimento de Rostow, Nurkse e Myrdal com a teoria do desenvolvimento de Celso Furtado, 2011, $144 \mathrm{f}$. Dissertação (Mestrado) - Universidade Federal de São Carlos, 03/03/2011.

GRAU, Eros. Notas sobre a noção de norma-objetivo, in Revista de Direito Público $\mathrm{n}^{\circ} 71$. São Paulo: Editora Revista dos Tribunais, 1984. . A ordem econômica na Constituição de 1988, 12ª edição. São Paulo: Malheiros, 2007. 
Direito, conceitos e normas jurídicas. São Paulo: Revista dos Tribunais, 1988.

GURRIERI, Adolfo (org.). O manifesto latino-americano e outros ensaios. Rio de Janeiro: Contraponto: Centro Internacional Celso Furtado, 2011.

HEERJE, Arnold. Schumpeter on the economics of innovation and the development of capitalism.Cheltenhan, UK; Northhampton, USA: Edward Elgar, 2006.

HELLER, Herman. La soberanía:contribución a la teoría del derecho estatal y del derecho internacional. Cidade do México: UNAM, 1965.

HIRSCHMAN, Albert. La estrategia del desarrollo econômico. Cuidad de México: Fondo de Cultura Económica, 1973.

JELLINEK, Georg. Teoría General del Estado. Tradução ao espanhol da $2^{\mathrm{a}}$ edição alemã. Montevidéu-Buenos Aires: Editorial BdeF, 2005.

JUSTEN FILHO, Marçal. Curso de Direito Administrativo, $1^{\text {a }}$ Edição. São Paulo: Saraiva, 2005 .

KASER, Max. Direito Privado Romano. Lisboa: Fundação Calouste Gulbenkian, 1999.

LENIN, Vladmir Ilich. O desenvolvimento do capitalismo na Rússia. O processo de formação do mercado interno para a grande indústria. São Paulo: Abril Cultural, 1982.

LOWENSTEIN, Karl. Brazil under Vargas. Nova Iorque: The Macmillan Company, 1942.

MACHADO, Paulo Affonso Leme. Direito Ambiental Brasileiro, $15^{\text {a }}$ edição, São Paulo: Malheiros, 2007.

MARQUES, Cláudia Lima; MIRAGEM, Bruno; LIXINSKI, Lucas. Desenvolvimento e consumo - bases para uma análise da proteção do consumidor como direito humano. In: 
PIOVESAN, Flávia \& SOARES, Inês Virgínia Prado. Direito ao Desenvolvimento. Belo Horizonte: Ed. Forum, 2010.

MARQUES Neto, Floriano de Azevedo. O regime jurídico das utilidades públicas: função social e exploração econômica. São Paulo: Tese de Livre Docência, 2008.

MARX. Karl. O capital:crítica da economia política, Vol I, Tomo II. São Paulo: Nova Cultural, 1985.

MAYER, Otto. Derecho Administrativo Alemán. Tomo III, Buenos Aires : Editorial Depalma, 1951.

MEIRELLES, Hely Lopes. Direito Administrativo Brasileiro, $16^{\mathrm{a}}$ edição. São Paulo: Revista dos Tribunais, 1991.

MELLO, Celso Antonio Bandeira de. Curso de Direito Administrativo. São Paulo: Malheiros, $28^{\mathrm{a}}$ Edição, 2011.

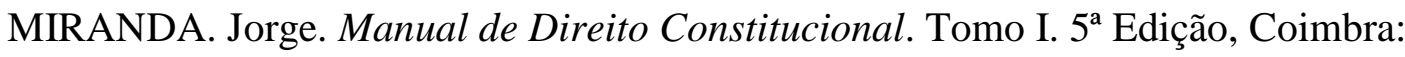
Coimbra Editora, 2003.

MONCADA. Luis S. Cabral de. Direito Econômico. $5^{\text {a }}$ edição, Coimbra: Coimbra Editora, 2007.

MORAES, Alexandre de. Constituição do Brasil interpretada, $7^{\text {a }}$ edição. São Paulo: Atlas, 2007.

MOREIRA, Vital. Economia e Constituição. 2a Edição, Coimbra: Coimbra Editora, 1979.

MOREIRA NETO. Diogo de Figueiredo. O Estado e a economia na Constituição de 1988. Revista de Informação Legislativa, Brasília: Senado Federal, v. 26, nº 102,abr/jun 1989. 
PATRÍCIO, J. Simões. Curso de Direito Econômico. $2^{\text {a }}$ Edição, Lisboa: Associação Acadêmica da Faculdade de Direito de Lisboa, 1981.

PAULA. João Antônio de. O mercado e o mercado interno no Brasil: conceito e história. História Econômica \& História de Empresas, 2002, vol. 1, p. 7-39.

PEREIRA. Caio Mario da Silva. Instituições de Direito Civil, vol I, 22 a edição. Rio de Janeiro: Editora Forense, 2007.

PEREZ, Reginaldo Teixeira. Pensamento político de Roberto Campos. Rio de Janeiro: Ed. FGV, 1999.

PERROUX, François. L'Economie du XX $X^{e}$ siècle. Grenoble: Presses Universitaires de Grenoble, $2^{a}$ edição, 1991.

POLANYI, Karl. A grande transformação: as origens da nossa época, $3^{\text {a }}$ edição. Rio de Janeiro: Ed. Campus, 1980.

PONTES DE MIRANDA, Francisco Cavalcanti. Comentários à Constituição de 1967. São Paulo: Editora Revista dos Tribunais, 1968.

PREBISCH. Raúl. Crescimento, desequilíbrios e disparidades: interpretação do processo de desenvolvimento econômico. In: GURRIERI, Adolfo (org.). O Manifesto LatinoAmericano e outros ensaios. Rio de Janeiro: Contraponto: Centro Internacional Celso Furtado, 2011. . Os principais problemas da técnica preliminar de programação. In: GURRIERI, Adolfo (org.). O Manifesto Latino-Americano e outros ensaios. Rio de Janeiro: Contraponto: Centro Internacional Celso Furtado, 2011. O mercado comum latino-americano In: GURRIERI, Adolfo (org.). O Manifesto Latino-Americano e outros ensaios. Rio de Janeiro: Contraponto: Centro Internacional Celso Furtado, 2011. 
O desenvolvimento econômico da América Latina e seus principais problemas.

In: BIELSCHOWSKY, Ricardo (org.). Cinquenta anos de pensamento na CEPAL. Rio de Janeiro: Record: CEPAL, 2000.

Problemas teóricos e práticos do crescimento econômico. In: GURRIERI,

Adolfo (org.). O manifesto latino-americano e outros ensaios. Rio de Janeiro:

Contraponto: Centro Internacional Celso Furtado, 2011.

RODRÍGUEZ, Ennio. La endogeneización del cambio tecnológico: un desafio para el desarrollo. In: SUNKEL, Osvaldo. El desarrollo desde dentro: un enfoque neoestruturalista para La América Latina. Ciudad de Mexico: Fondo de Cultura Económica, 1995.

RODRÍGUEZ, Octavio. O estruturalismo latino-americano. Rio de Janeiro: Civilização Brasileira: CEPAL, 2009.

ROSTOW, Walt Whitman. The stages of economic growth, $3^{\text {a }}$ edição. Cambridge: Cambridge University Press, 2004.

ROUAIX, Ing. Pastor. Genesis de los artículos 27 y 123 de la constituicion política de 1917. Puebla: Gobierno del Estado de Puebla, 1945.

SACHS, Ignacy. Um projeto para o Brasil: a construção do mercado nacional como motor do desenvolvimento. In: BRESSER-PEREIRA, Luiz Carlos; REGO, José Marcio. A grande esperança em Celso Furtado: ensaios em homenagem aos seus 80 anos. São Paulo: Ed. 34, 2001.

SANDRONI. Paulo. Dicionário de economia do século XXI, Rio de Janeiro: Record, 2005

SCHUMPETER, Joseph Alois. Business cycles, vol I. New York: Bartelby's Books: Martino Publishing, 2005. A teoria do desenvolvimento econômico. São Paulo: Nova Cultural, $3^{a}$ edição, 1988. 
SECCO, Lincoln. A Revolução dos Cravos e a crise do império colonial português. São Paulo: Alameda, 2004.

SILVA, José Afonso da. Direito Ambiental Constitucional, 9a edição. São Paulo: Malheiros, 2011. . Aplicabilidade das normas constitucionais. $7^{\mathrm{a}}$ Edição. São Paulo: Malheiros, 2007. . Curso de Direito Constitucional Positivo. São Paulo: Malheiros, $19^{a}$ Edição, 2001 . Comentário contextual á Constituição de 1988, 6ª edição. São Paulo: Malheiros, 2009.

SIMONSEN, Roberto. À margem da profissão. São Paulo: São Paulo Editora, 1932. Evolução industrial do Brasil e outros estudos. São Paulo: Companhia Editora Nacional, 1973. Orientação industrial brasileira. In: CARONE, Edgard (org.). Evolução industrial do Brasil e outros estudos. São Paulo: Editora Nacional: Editora USP, 1973. História Econômica do Brasil (1500/1820). São Paulo, Companhia Editora Nacional, 8ª edição, 1978.

SKIDMORE, Thomas E. Brasil: de Getúlio Vargas a Castelo Branco (1930-1964). $7^{\mathrm{a}}$ edição. Rio de Janeiro: Paz e Terra, 1982.

SOUZA, Washington Peluso Albino de. Direito econômico. São Paulo: Saraiva, 1980. Teoria da constituição econômica. Belo Horizonte: Del Rey, 2002.

SUNKEL, Osvaldo. El desarrollo desde dentro: un enfoque neoestruturalista para La América Latina. Ciudad de Mexico: Fondo de Cultura Económica, 1995.

TAVARES, Maria da Conceição. Da substituição de importações ao capitalismo financeiro: ensaios sobre economia brasileira. $2^{a}$ edição. Rio de Janeiro: Zahar, 1973. 
VERONESE, Alexandre. Arts. 218 e 219. In: BONAVIDES, Paulo; MIRANDA, Jorge e AGRA, Walber Moura (Coords.). Comentários à Constituição Federal de 1988. Rio de Janeiro: Forense, 2009.

WOOD, Ellen Meiksins. A origem do capitalismo. Rio de Janeiro: Jorge Zahar Editor, 2001.

WEBER, Max. Economia y sociedad. Esbozo de sociología comprensiva. México: Fondo de Cultura Económica, 15ª reimpressão, 2004. 